UNIVERSIDADE DE SÃO PAULO

ESCOLA DE ENFERMAGEM DE RIBEIRÃO PRETO

ELIZELAINE DE CHICO CICOGNA

\title{
Crianças e adolescentes com câncer: experiências com a quimioterapia
}

Ribeirão Preto 
ELIZELAINE DE CHICO CICOGNA

Crianças e adolescentes com câncer: experiências com a quimioterapia

Dissertação apresentada à Escola de Enfermagem de Ribeirão Preto da Universidade de São Paulo para obtenção do título de Mestre em Enfermagem junto ao Programa de Pós-Graduação Enfermagem em Saúde Pública.

Área de concentração: Enfermagem em Saúde Pública

Linha de pesquisa: Assistência à criança e ao adolescente Orientadora: Profa. Dra. Regina Aparecida Garcia de Lima

Ribeirão Preto

2009 


\section{AUTORIZO A REPRODUÇÃO E DIVULGAÇÃO TOTAL E PARCIAL DESTE TRABALHO, POR QUALQUER MEIO CONVENCIONAL OU ELETRÔNICO, PARA FINS DE ESTUDO E PESQUISA, DESDE QUE CITADA A FONTE.}

\section{FICHA CATALOGRÁFICA}

Cicogna, Elizelaine de Chico

Crianças e adolescentes com câncer: experiências com a quimioterapia. Ribeirão Preto, 2009.

142 p.: il.; $30 \mathrm{~cm}$

Dissertação de Mestrado, apresentada à Escola de Enfermagem de Ribeirão Preto/USP. Área de concentração: Enfermagem em Saúde Pública.

Orientador: Lima, Regina Aparecida Garcia.

1. Neoplasia.

2. Quimioterapia.

3. Criança.

4. Adolescente.

5. Enfermagem Pediátrica. 


\section{FOLHA DE APROVAÇÃO}

Elizelaine de Chico Cicogna

Crianças e adolescentes com câncer: experiências com a quimioterapia

Dissertação apresentada à Escola de Enfermagem de Ribeirão Preto da Universidade de São Paulo para obtenção do título de Mestre em Enfermagem junto ao Programa de Pós-Graduação Enfermagem em Saúde Pública.

Área de concentração: Enfermagem em Saúde Pública.

Linha de pesquisa: Assistência à criança e ao adolescente.

Aprovado em:

I

Banca Examinadora

Prof. Dr. Instituição:

Julgamento: Assinatura:

Prof. Dr. Instituição:

Julgamento: Assinatura:

Prof. Dr. Instituição:

Julgamento: Assinatura: 
Dedico este trabalfo a todas as crianças e adolescentes e, em especial, àqueles que me permitiram conhecer uma infima parte de suas vivências e que tornaram este estudo um aprendizado de vida. 


\section{AGRADECIMENTOS}

A Deus, pela vida, pela saúde física e mental e pelas oportunidades de crescimento concedidas.

À Profa. Dra. Regina Aparecida Garcia de Lima, exemplo de dedicação e comprometimento profissional, pela paciência, pelas preciosas orientações e pelo incentivo demonstrado no decorrer deste aprendizado.

À Profa. Dra. Ana Maria de Almeida e Dra. Marysia M. R. P. De Carlo, pelas importantes contribuições no Exame de Qualificação.

À Profa. Dra. $\mathcal{N}$ eeli Marchioro Liston Andrade Ferreira que me iniciou na pesquisa científica, pelas orientações, pelo incentivo e pela amizade.

À minha família, em especial meus pais, Antônio Carlos e Elizabeth, meu irmão, minha cunhada, sobrinhos e avós, personagens importantes em cada novo desafio, pelo amor, ensinamentos, apoio e cumplicidade durante toda a minha caminhada.

Ao meu esposo Thiago, pelo amor, incentivo, compreensão e suporte indispensável no meu dia a dia.

À família do meu esposo e aos amigos que sempre me incentivaram a ultrapassar as barreiras e dificuldades, estimulando em todo o trajeto.

À Universidade de São Paulo e à Escola de Enfermagem de Ribeirão Preto, pelo conhecimento disponibilizado e contribuição em minha formação acadêmica e pessoal.

Aos funcionários da Enfermaria Pediátrica, do Ambulatório de Pediatria e da Central de Quimioterapia do Hospital das Clínicas da Faculdade de Medicina de Ribeirão Preto (HCFMRP-USP), por me acolherem, orientarem e possibilitarem o meu envolvimento junto aos sujeitos deste estudo. 
"E sorriu, percebendo que estava vendo coisas que nunca vira. Nãa, não é que nunca tivesse visto. Seus olhos as haviam notado, mas o seu coração não as havia acolhido. E ela compreendeu que o olho só vê aquilo que o coração deseja." (por Rubem Alves em “A toupeira que queria ver o cometa", 2001) 


\section{RESUMO}

CICOGNA, E. C. Crianças e adolescentes com câncer: experiências com a quimioterapia. 2009. 142 f. Dissertação (Mestrado) - Escola de Enfermagem de Ribeirão Preto, Universidade de São Paulo, Ribeirão Preto, 2009.

A quimioterapia é uma das abordagens terapêuticas para o tratamento do câncer e, no caso específico das crianças e adolescentes, a mais frequente, de forma individual ou associada a outras modalidades. Tem sido fonte de preocupações, questionamentos e dúvidas, tanto por parte das crianças e adolescentes quanto de seus familiares, por seus efeitos colaterais físicos e psicológicos. $O$ presente estudo tem por objetivo compreender como as crianças e os adolescentes com câncer vivenciam a experiência da quimioterapia, a partir de seus próprios relatos, visto que, ao conhecer suas demandas e sentimentos, podemos incorporá-los ao plano de cuidados de enfermagem e contribuir para uma assistência qualificada e dirigida à qualidade de vida da criança, do adolescente e de sua família. Exploratório e com análise qualitativa dos dados este estudo contou com a participação de 10 crianças e adolescentes entre oito e 18 anos, em diferentes momentos da terapêutica quimioterápica. Para a coleta dos dados, utilizamos como instrumentos a entrevista semiestruturada e a observação livre, complementadas com dados do prontuário dos sujeitos em questão. A análise do material empírico seguiu a técnica de análise de conteúdo. Após a caracterização dos sujeitos da pesquisa, os resultados foram agrupados ao redor de três grandes temas, seguidos dos respectivos subtemas: a doença, compreendendo a trajetória até o diagnóstico e o conhecimento sobre a doença; a quimioterapia, a partir do impacto do tratamento, as características dos quimioterápicos e a visão do processo e, por fim, a rede de apoio que incluiu a família, os amigos e a religião. O estudo nos permitiu compreender que, para as crianças e adolescentes, a experiência da quimioterapia está intimamente ligada à experiência do câncer, sendo impossível entender a dimensão da terapêutica sem antes compreender a base desta questão, o câncer infanto-juvenil. Lembrada, principalmente por seus efeitos colaterais e o sofrimento, a quimioterapia causa, de imediato, um forte impacto, deixando sobressair o medo. Passado este primeiro impacto, principalmente das alterações físicas, as preocupações dirigem-se à recuperação da doença, ou seja, à cura. Mencionam que o câncer interrompe uma vida até então normal e provoca dúvidas quanto ao futuro e mesmo o presente. Em contrapartida, com o tempo, relatam que o processo terapêutico, incluindo a quimioterapia, levou-os a valorizar mais a vida. Brincar, ter a família e os amigos por perto, buscar Deus, conhecer a doença e enfrentá-la, se envolver em todo o processo e, acima de tudo, acreditar no sucesso foram estratégias utilizadas durante a quimioterapia, terapêutica sofrida, restritiva, mas acima de tudo, responsável pela cura da criança e do adolescente.

DESCRITORES: Neoplasia. Quimioterapia. Criança. Adolescente. Enfermagem Pediátrica. 


\section{ABSTRACT}

CICOGNA, E. C. Child and adolescents with cancer: experiences with chemotherapy. 2009. 142 f. Thesis (Masters) - University of São Paulo at Ribeirão Preto College of Nursing, Ribeirão Preto, 2009.

Chemotherapy is one of the therapies used in cancer treatment. Separately or associated to other therapies, it is the most frequently used to treat children and adolescents. Due to its physical and psychological collateral effects, it has been source of preoccupations, questions and doubts, both for children and adolescents as well as their relatives. This exploratory and qualitative study aimed to understand how children and adolescents with cancer experience chemotherapy, from their own reports. Knowing their demands and feelings permits to incorporate them to the nursing care plan and contributes to a quality care, targeting the quality of life of children, adolescents and their families. Participants were 10 children and adolescents between 8 and 18 years of age, on different moments of chemotherapy. Data collection was done through semi-structured interview and free observation, added by data from subjects' patient files. Analysis of the empirical material was done through content analysis. After characterization of the research subjects, results were grouped into three themes and their respective subthemes: disease, understanding the trajectory to diagnosis and knowledge about the disease; chemotherapy, the treatment impact, characteristics of chemotherapeutic drugs and the view of the process and, lastly, the support network, which includes family, friends and religion. The study permitted to understand that, for children and adolescents, the chemotherapy experience is closely related to the cancer experience, and it is impossible to understand the dimension of the therapy without previously understanding the basis of the issue: child and juvenile cancer. Chemotherapy is mainly reminded by its collateral effects and suffering. It has a strong impact on participants, showing the fear caused by it. After the initial impact, mainly due to physical changes, preoccupations are related to disease recovery, that is, cure. They mention that cancer interrupts what was so far a normal life and causes doubts regarding the future and even present life. On the other hand, according to their reports, treatment, including chemotherapy, made them value life more. Playing, being close to family and friends, searching for Good, knowing and facing the disease, getting involved in the process and, above all, believing in success, were the strategies used during chemotherapy, which is a restrictive therapy, that causes suffering, but which is primarily responsible for children and adolescent cure.

DESCRIPTORS: Neoplasms. Drug Therapy. Child. Adolescent. Pediatric Nursing. 


\section{RESUMEN}

CICOGNA, E. C. Niños y adolescentes con cáncer: experiencias con la quimioterapia. 2009. 142 h. Disertación (Maestría) - Escuela de Enfermería de Ribeirão Preto, Universidad de São Paulo, Ribeirão Preto, 2009.

La quimioterapia es una de las terapias para el tratamiento del cáncer y, en el caso específico de los niños y adolescentes, la más frecuente, de forma individual o asociada a otras modalidades. Por sus efectos colaterales físicos y psicológicos, tiene sido fuente de preocupaciones, cuestionamientos y dudas tanto por parte de los niños y adolescentes cuanto de sus familiares. El presente estudio exploratorio y cualitativo objetiva comprender como los niños y los adolescentes con cáncer viven la experiencia de la quimioterapia, a partir de sus propios relatos. Conocer sus demandas y sentimientos permite añadirlas al plan de cuidados de enfermería y contribuir para una atención cualificada y dirigida a la calidad de vida del niño, del adolescente y de su familia. El estudio tuvo la participación de 10 niños y adolescentes entre ocho y 18 años, en diferentes momentos de la quimioterapia. Para la recolecta de los datos, los instrumentos utilizados fueron la entrevista semiestructurada y la observación libre, complementadas con datos del registro médico de los sujetos en cuestión. El análisis del material empírico fue hecho por análisis de contenido. Después de la caracterización de los sujetos de la investigación, los resultados fueron agrupados en tres grandes temas, seguidos de los respectivos subtemas: la enfermedad, comprendiendo la trayectoria hacia el diagnóstico y el conocimiento acerca de la enfermedad; la quimioterapia, a partir del impacto del tratamiento, las características de los quimioterápicos y la visión del proceso y, por fin, la red de apoyo que incluye la familia, los amigos y la religión. El estudio permitió comprender que, para los niños y adolescentes, la experiencia de la quimioterapia está estrechamente ligada a la experiencia del cáncer, siendo imposible entender la dimensión de la terapia sin antes comprender la base de esa cuestión: el cáncer infanto-juvenil. La quimioterapia es recordada principalmente por sus efectos colaterales y el sufrimiento, y causa, de inmediato, un fuerte impacto, dejando sobresalir el miedo. Después del primer impacto, principalmente de las alteraciones físicas, las preocupaciones se dirigen hacia la recuperación de la enfermedad, o sea, la cura. Mencionan que el cáncer interrumpe una vida hasta el momento normal y provoca dudas cuanto al futuro y mismo el presente. Por otro lado, con el tiempo, relatan que el proceso de la terapia, incluyendo la quimioterapia, les llevó a valorar más la vida. Brincar, estar cerca de la familia y de los amigos, buscar Dios, conocer la enfermedad y enfrentarla, se involucrar en todo el proceso y, sobre todo, acreditar en el suceso, fueron las estrategias utilizadas durante la quimioterapia, una terapia restrictiva y que causa sufrimiento, pero por encima de todo, responsable por la cura del niño y del adolescente.

DESCRIPTORES: Neoplasias. Quimioterapia. Niño. Adolescente. Enfermería Pediátrica. 


\section{LISTA DE ILUSTRAÇÕES}

Quadro 1 - Possíveis diagnósticos diferenciais dos tumores da infância

Quadro 2 - Principais queixas relacionadas com diagnóstico de tumor na infância..22

Quadro 3 - Classificação dos quimioterápicos, de acordo com a estrutura química e função em nível celular (similaridade de ação)

Quadro 4 - Classificação dos quimioterápicos, de acordo com a especificidade no ciclo celular..... 30

Quadro 5 - Caracterização das crianças e adolescentes, segundo o nome, idade, escolaridade, atividade laboral, diagnóstico, tempo de diagnóstico, tratamento, início do tratamento quimioterápico, número de ciclos quimioterápicos, religião e data da entrevista. Ribeirão Preto, 2008 


\section{LISTA DE SIGLAS}

5-FU

5 - Fluorouracil

Ara-C

Citosina Arabinoside

EUA

Estados Unidos da América

$\mathrm{HC}$

Hospital das Clínicas

HCFMRP - USP Hospital das Clínicas da Faculdade de Medicina de Ribeirão

Preto da Universidade de São Paulo

INCA Instituto Nacional de Câncer

LLA Leucemia Linfoide Aguda

LMA Leucemia Mieloide Aguda

QT Quimioterapia

RT Radioterapia

SNC

Sistema Nervoso Central

UE

Unidade de Emergência do Hospital das Clínicas

USP

Universidade de São Paulo 


\section{SUMÁRIO}

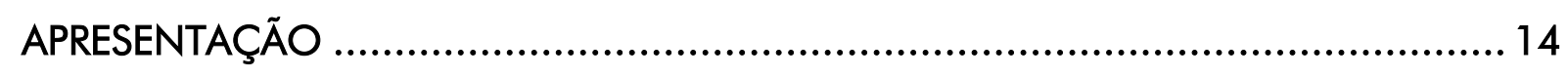

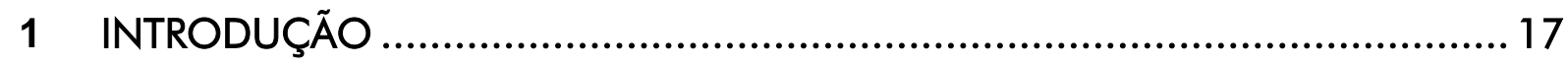

1.1 Particularidades do câncer infanto-juvenil...........................................18

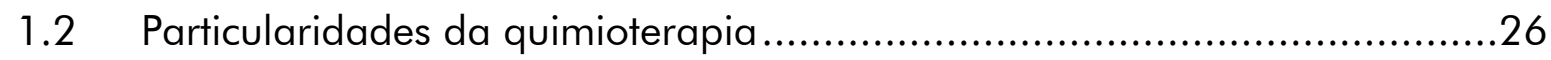

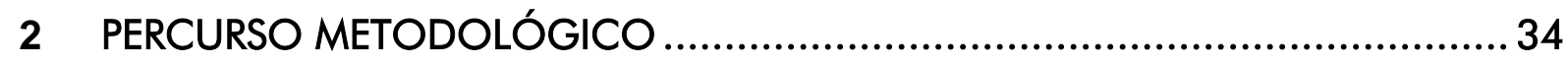

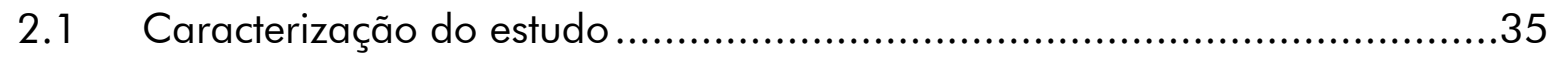

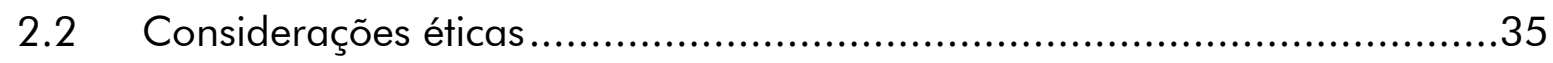

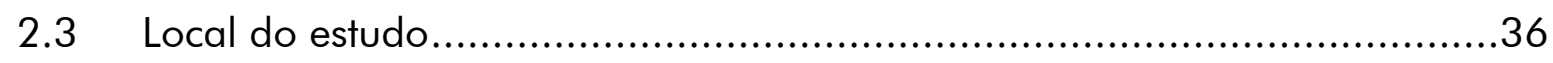

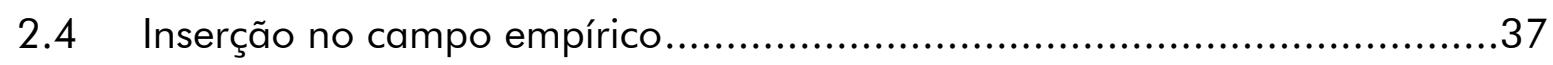

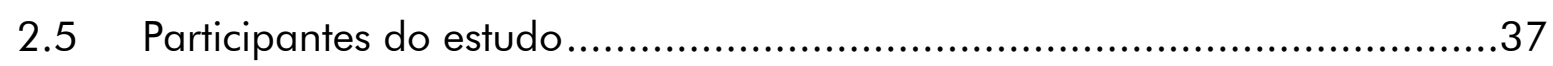

2.6 Procedimentos para coleta e registro dos dados .....................................40

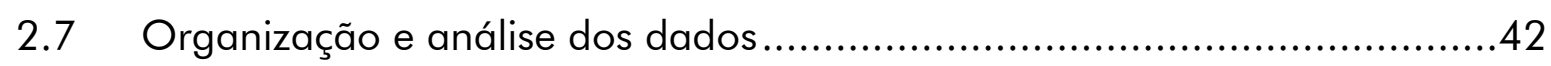

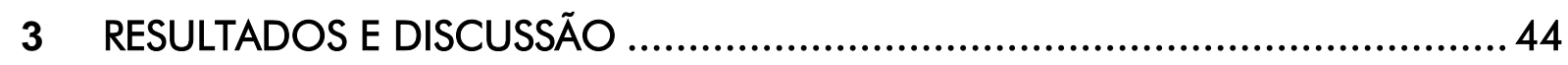

3.1 CARACTERIZAÇÃO DAS CRIANÇAS E DOS ADOLESCENTES …................45

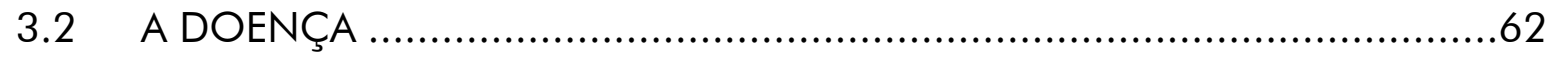

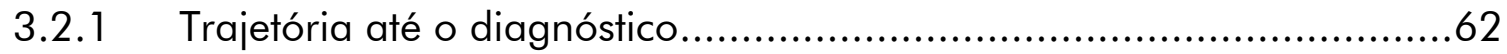

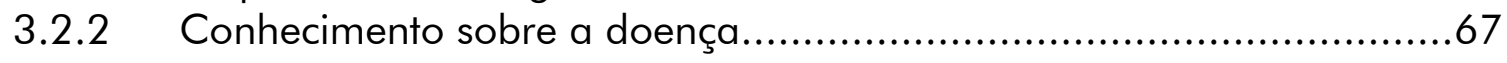

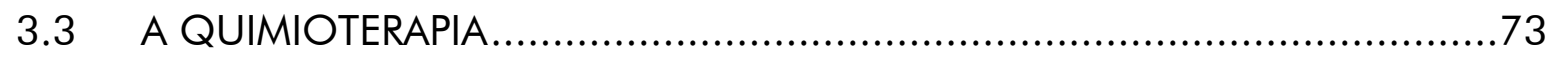

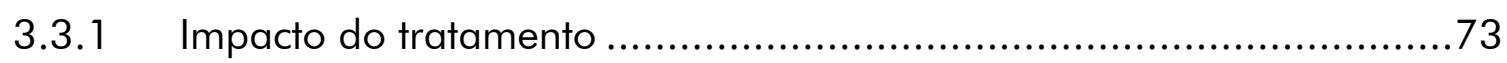

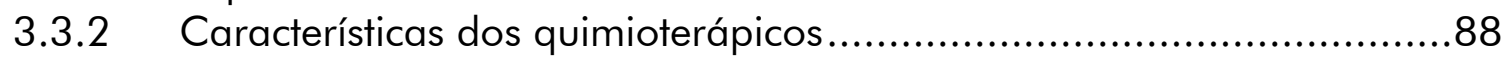

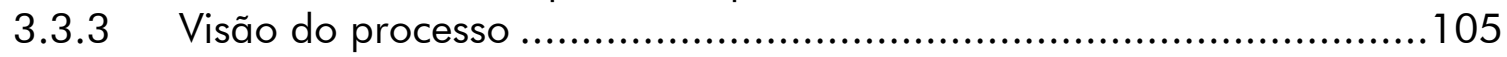

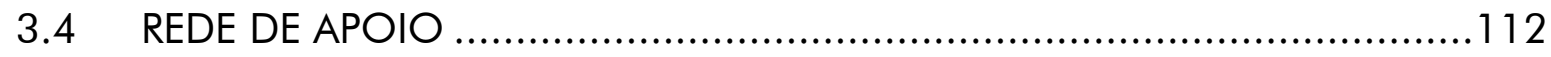

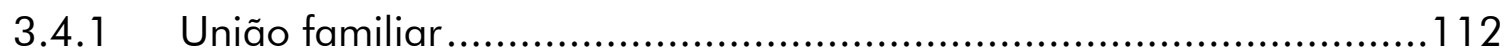

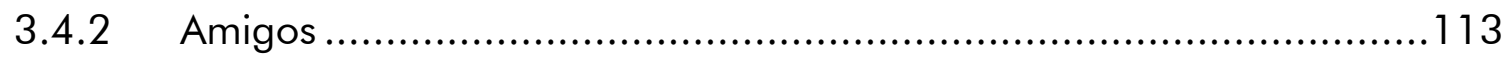

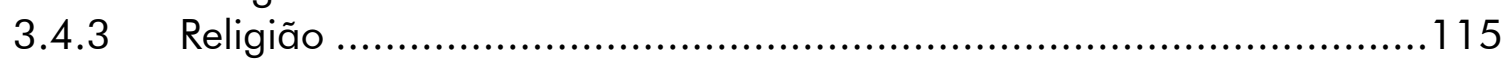

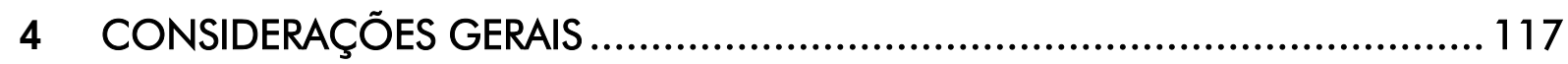

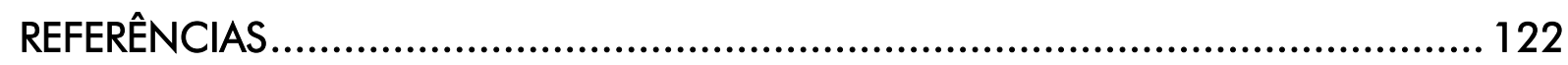

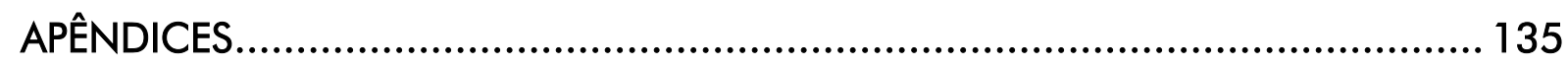

APÊNDICE I - Termo de Consentimento Livre e Esclarecido.................................136 
APÊNDICE II - Instrumento de Coleta de dados - Entrevista ................................138

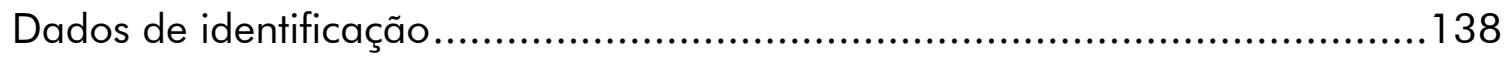

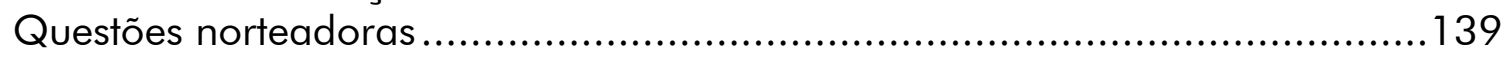

APÊNDICE III - Instrumento de Coleta de dados - Observação ............................140

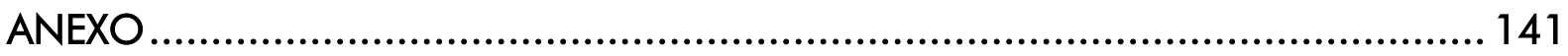

Aprovação do Comitê de Ética em Pesquisa.....................................................142 
APRESENTAÇÃO 
Iniciei a graduação em enfermagem, em 2001, na Universidade Federal de São Carlos e, em 2002, comecei a desenvolver a minha primeira atividade de iniciação científica. Motivada por experiências familiares, decidi trabalhar com pacientes com câncer, e o primeiro tema foi a dor do doente oncológico. Esta experiência possibilitou, a partir dos relatos dos doentes, conhecer as suas representações sociais sobre a dor oncológica (DE CHICO; HAYASHI; FERREIRA, 2003). Em 2003, com uma nova pesquisa, utilizamos o Modelo Calgary como uma ferramenta no estudo cujo objetivo foi reconhecer o significado da doença para a família de pacientes oncológicos, buscando compreender a influência desta doença sobre os familiares, as condições de vulnerabilidade e os recursos disponíveis (HAYASHI; DE CHICO; FERREIRA, 2004).

Durante a graduação, tive a oportunidade de estagiar no Hospital Amaral Carvalho em Jaú - Estado de São Paulo, referência no tratamento de câncer. A experiência vivenciada neste hospital durante um mês trouxe a certeza de que a Oncologia era a minha área de escolha profissional.

No último ano da graduação, meu Trabalho de Conclusão de Curso (TCC) foi voltado para as ações educativas dos doentes fora de possibilidade de cura, sendo, no caso, todos com diagnóstico principal de câncer (DE CHICO; HAYASHI; FERREIRA, 2004). A escolha do tema foi influenciada pela escassez de serviços ou ações direcionadas a esta população na cidade de desenvolvimento do estudo.

Com o término da graduação, iniciei minha jornada laboral. No entanto, a partir desse momento, não foi possível focar os cuidados em pacientes com câncer, visto que o local de trabalho no qual me inseri era uma unidade mista de saúde.

Ao iniciar o curso de pós-graduação, em 2007, retomo os estudos no campo da Enfermagem Oncológica, mais especificamente com crianças e adolescentes portadores de câncer, durante o tratamento quimioterápico, sendo este meu objeto de estudo.

A escolha, neste momento, em trabalhar com crianças e adolescentes em tratamento quimioterápico se deu pelo forte desejo de encontrar, junto aos doentes

\footnotetext{
${ }^{1}$ Esta dissertação foi revisada seguindo a Nova Ortografia da Língua Portuguesa (1990), em vigor a partir de $1^{\text {o }}$ de janeiro de 2009.
} 
com câncer, perspectivas positivas, energia, esperança e vida, fato que até então não era marcante, pois, na experiência com pacientes adultos, observava que eles enxergavam o aparecimento do câncer como o fim da vida, a falta de possibilidade de cura física e a perda da qualidade de vida.

Assim, introduziremos o tema com as particularidades do câncer infanto-juvenil e da quimioterapia, a partir de dados estatísticos de incidência e mortalidade, do levantamento de sinais e sintomas observados para diagnósticos diferenciais, da classificação das drogas quimioterápicas, da preocupação com os efeitos da terapêutica e, portanto, com os sobreviventes e da influência do processo de doença e tratamento sobre a qualidade de vida das crianças, dos adolescentes e seus familiares. Desta forma, procuraremos entender o processo de tratamento quimioterápico, a partir da visão das crianças e dos adolescentes, possibilitando colaborar para uma assistência qualificada e direcionada à qualidade de vida.

Posteriormente, apresentaremos, no percurso metodológico, a caracterização do estudo, os critérios de inclusão dos participantes, os procedimentos de coleta e registros e, por fim, as questões relacionadas à organização e análise dos dados.

A terceira etapa será deslumbrada pelos resultados do estudo, sendo, num primeiro momento, abordados aspectos da caracterização das crianças e dos adolescentes para, em seguida, apresentar e discutir os diversos temas que emergiram dos relatos.

Por fim, nas considerações gerais, faremos uma discussão sobre os principais temas levantados e apontaremos, na visão das crianças e adolescentes, conclusões sobre o processo quimioterápico e suas implicações. 
INTRODUÇÃO 


\subsection{Particularidades do câncer infanto-juvenil}

Os avanços científicos permitiram reconhecer que o câncer não é apenas um tipo de doença, mas um grande conjunto de doenças que pode ser agrupado pela similaridade quanto ao crescimento desordenado de células incontroláveis que invadem tecidos e órgãos, podendo atingir outras regiões do corpo a partir de metástases, sejam elas disseminadas por meio dos vasos sanguíneos e/ou linfáticos (BRASIL, 2008a).

Nos Estados Unidos da América (EUA), foi estimado, para 2006, um total de 1.399.790 novos casos e 564.830 mortes por câncer (JEMAL et al., 2006). Para o ano de 2007, estimaram-se 10.400 novos casos de câncer entre crianças de 0 a 14 anos de idade (NATIONAL CANCER INSTITUTE, 2008).

Em crianças entre 1 e 14 anos de idade, nos EUA, o câncer é a segunda principal causa de morte (acidentes são a primeira causa). Os cânceres mais comuns entre crianças nesta faixa etária são as leucemias, principalmente Leucemia Linfoide Aguda (LLA), seguidas dos que acometem o sistema nervoso central (SNC), sarcomas de partes moles, Linfoma não Hodgkin e, por fim, tumor de Wilms (JEMAL et al., 2006).

Objetivando descrever a incidência de câncer infantil nos EUA, um estudo norte-americano, ao analisar registros de mais de $90 \%$ da população de 0 a 19 anos, no período entre 2001 e 2003, apontou um total de 36.446 casos de cânceres infanto-juvenis, o que confere, ajustadas as idades, uma taxa de incidência de 165,92 por milhão. De todos os cânceres, as leucemias foram os tipos mais comuns $(26,25 \%)$ e nestas, a LLA foi a mais incidente. As neoplasias do SNC foram o segundo câncer mais comum (17,57\%), seguidas pelos linfomas (14,57\%), totalizando quase $60 \%$ dos cânceres nesta faixa etária. A partir dos ajustes nas idades, combinados todos os cânceres, a taxa de incidência entre meninos foi de 174,28 por milhão e a de meninas de 157,14 por milhão (JUN LI et al., 2008).

A partir desse levantamento, os cânceres que ocorreram mais frequentemente em meninos incluíram LLA, Linfoma não Hodgkin, Linfoma de Burkit, hepatoblastoma, osteossarcoma, tumor de Ewing, rabdomiossarcoma, tumores 
intracraniais e tumores de células germinativas. Já em meninas, os cânceres que ocorreram com maior frequência foram o neuroblastoma e outros tumores renais não epiteliais, extracranianos e de células germinativas, carcinomas da tireoide e melanomas malignos (JUN LI et al., 2008).

As taxas de incidência se mostraram menores entre crianças ( 0 a 14 anos) do que em adolescentes (15-19 anos) e, entre estes últimos, os cânceres mais frequentes foram os linfomas, tumores ósseos, sarcomas de partes moles, neoplasias de células germinativas, outras neoplasias epiteliais e, por fim, neoplasias não específicas (JUN Ll et al., 2008).

Nos EUA, 80\% das crianças têm doença avançada ao diagnóstico, apresentando metástases distantes em contraste com os $20 \%$ dos diagnósticos avançados em adultos, o que implica em rever conhecimentos acerca do tema e estar alerta para os sinais da doença em crianças e adolescentes (THOMPSON, 2003). início dos sinais e sintomas de que há algo de errado com a criança é o ponto de partida para as mudanças de rotina, tanto da criança quanto de seus familiares, momento em que a criança passa a ser alvo de todas as atenções, momento de dúvidas e de situações novas, momento de uma experiência totalmente particular e singular (FRANÇOSO, 2001).

Com relação à incidência no Brasil, a ordem de aparecimento dos diferentes tipos de câncer na infância é semelhante à de países em desenvolvimento, prevalecendo as leucemias com $29 \%$, os linfomas com $15,5 \%$ e os tumores do SNC com 13,4\%, diferentemente de países desenvolvidos que apresentam maiores incidências para leucemias, tumores do SNC e, posteriormente, os linfomas. Observamos que as leucemias têm maior representatividade entre 1 e 4 anos $(31,6 \%)$, seguidas dos linfomas entre a faixa etária de 15 a 18 anos $(35,6 \%)$ e dos tumores do SNC com média de $26 \%$ entre as faixas etárias de 1 a 4, 5 a 9 e 10 a 14 anos (BRASIL, 2008e).

Para o ano de 2008, estimaram-se 351.720 casos novos de câncer em todo o Brasil, à exceção dos tumores de pele não melanoma. Destes, são esperados cerca de 9.890 casos novos em menores de 18 anos de idade, correspondendo a valores entre $0,5 \%$ e $3 \%$ de todos os casos de neoplasia maligna, com predominância para o sexo masculino (BRASIL, 2007). 
Embora raro em números absolutos, comparado às incidências em adultos, o câncer infantil vem apresentando aumento nas taxas de incidência. Segundo dados do Registro Hospitalar de Câncer (RHC) do Estado de São Paulo, entre 2000 e 2001, os tumores pediátricos foram representados, segundo a ordem de incidência, por leucemias, linfomas, tumores do SNC, tumores ósseos, sarcomas de partes moles e outros. Entre 1999 e 2000, no Estado de São Paulo, obteve-se, pelo Registro Hospitalar de Câncer, uma estatística de 1,9\% dos óbitos por câncer em menores de 19 anos, sendo $37,8 \%$ para a faixa etária dos 13 aos 18 anos, 22,6\% de 1 a 4 anos e 5,9\% para os menores de 1 ano (FOSP, 2002).

Apesar de mais invasivos e do crescimento mais rápido dos tumores infantis, quando comparados aos dos adultos, o câncer infantil responde melhor ao tratamento e, geralmente, tem melhor prognóstico (BRASIL, 2007), apresentando, nos países desenvolvidos, uma taxa de 70 a $80 \%$ de sobrevida livre de doença, quando diagnosticado precocemente, no entanto, $25 \%$ dos casos ainda têm recidiva (OLIVEIRA et al., 2005). No Brasil, a LLA apresenta valores entre 70 e $80 \%$ de cura entre crianças e adolescentes (BRASIL, 2008b), no entanto, tem destaque a infecção como a principal causa de morte entre elas, o que coloca esta problemática como mais um foco para o cuidado (THOMPSON, 2003).

O câncer infantil acarreta grande desgaste psíquico e social com altos custos financeiros ligados ao diagnóstico, tratamento e sequelas. A mortalidade do câncer infantil varia entre os países, mas nos países em desenvolvimento é superada por doenças infecciosas e acidentes, precedendo, no entanto, as malformações congênitas, diferentemente de países desenvolvidos, onde o câncer infantil é a principal causa de morte nesta população (MIRRA; LATORRE; VENEZIANO, 2004).

Contrapondo-se às neoplasias de adultos, o câncer infanto-juvenil difere em diversos aspectos, como tipos, locais, etiologia, características e mesmo tratamento (THOMPSON, 2003). Os tumores infantis, em sua grande maioria, apresentam causas associadas desconhecidas (BRASIL, 2007) e pela falta de ligação direta destes com os fatores ambientais, a prevenção torna-se o grande desafio para o futuro e o diagnóstico precoce o maior ganho atual para o sucesso do tratamento (BRASIL, 2008b). 
Segundo Rodrigues e Camargo (2003), muitos fatores influenciam o diagnóstico do câncer infantil, e a redução da mortalidade e comorbidades depende da detecção precoce e do início rápido do tratamento.

O pediatra geral é frequentemente 0 primeiro a ser procurado para $\circ$ diagnóstico de queixas ainda inespecíficas das crianças, no entanto, aos primeiros sinais, elas dificilmente estão muito doentes, o que por vezes atrasa o diagnóstico. Neste momento, uma boa anamnese e um bom exame físico são fundamentais para a detecção precoce. A seguir (Quadro 1), encontramos os possíveis diagnósticos diferenciais dos tumores da infância (RODRIGUES; CAMARGO, 2003).

\begin{tabular}{ccc}
\hline \hline Sinais e sintomas & Condições não malignas & Câncer \\
\hline \hline Cefaleia, vômitos matinais & Enxaqueca, sinusite & $\begin{array}{c}\text { Tumor do Sistema Nervoso } \\
\text { Central }\end{array}$ \\
\hline Linfadenopatia & Infecção & $\begin{array}{c}\text { Linfomas, leucemia } \\
\text { Dor óssea }\end{array}$ \\
\hline Infecção, trauma & $\begin{array}{c}\text { Tumor ósseo, leucemia, } \\
\text { neuroblastoma }\end{array}$ \\
\hline Massa mediastinal & Cistos, bexigoma, fecaloma, \\
bolo de áscaris & $\begin{array}{c}\text { Tumor de Wilms, linfoma, } \\
\text { neuroblastoma }\end{array}$ \\
\hline Pancitopenia & Infecção, cistos & Linfoma, teratoma \\
\hline Sangramento & Coagulopatias, púrpuras & Leucemia \\
\hline \hline Fonte: RODRIGUES; CAMARGO, 2003. & & Leucemias \\
\hline
\end{tabular}

Quadro 1 - Possíveis diagnósticos diferenciais dos tumores da infância

No Quadro 2, apresentamos as principais queixas relacionadas com diagnósticos de tumor na infância, segundo Steuber e Nesbit Jr. (1997). 
Queixa

Possível câncer

\begin{tabular}{|c|c|}
\hline Drenagem crônica do ouvido & Rabdomiossarcoma, histiocitose \\
\hline Febre recorrente com dor óssea & Leucemias, sarcoma de Ewing \\
\hline Cefaleia matinal com vômitos & Tumor do sistema nervoso central \\
\hline $\begin{array}{c}\text { Adenopatia sem resposta a } \\
\text { antibiótico }\end{array}$ & Linfomas \\
\hline Mancha no olho & Retinoblastoma \\
\hline Proptose & $\begin{array}{c}\text { Leucemias, neuroblastoma, rabdomiossarcoma, } \\
\text { histiocitose }\end{array}$ \\
\hline Massa abdominal & $\begin{array}{c}\text { Tumor de Wilms, neuroblastoma, linfoma, } \\
\text { hepatoblastoma }\end{array}$ \\
\hline Anemia e fadiga & Leucemias, linfoma \\
\hline Dor óssea & $\begin{array}{c}\text { Leucemias, sarcoma de Ewing, neuroblastoma, } \\
\text { osterossarcoma }\end{array}$ \\
\hline Perda de peso & Linfomas \\
\hline Sangramento vaginal & $\begin{array}{l}\text { Rabdomiossarcoma, tumor de células } \\
\text { germinativas }\end{array}$ \\
\hline
\end{tabular}

Fonte: STEUBER; NESBIT Jr., 1997

Quadro 2 - Principais queixas relacionadas com diagnóstico de tumor na infância

Antes considerada doença aguda e fatal, o câncer hoje tem características de doença crônica e mesmo com o bom prognóstico quando descoberto no início, a família e a criança sentem-se ameaçadas de morte quando recebem o diagnóstico (VALLE, 2006). Dúvidas aparecem em todas as fases, desde o momento do diagnóstico, passando pelo tratamento e pela fase de cura. Tais dúvidas dizem respeito ao que é a doença, o que deve ser feito, se o tratamento terá sucesso, enfim, dúvidas sobre um novo mundo, o qual é totalmente separado do que até então a criança e a família estavam acostumadas a vivenciar (FRANÇOSO, 2001).

A descoberta do diagnóstico provoca nos pais uma grande incerteza e estresse psicossocial, o que os deixa vulneráveis e inseguros com as questões relacionadas a 
como vai ser o processo, se seus filhos irão sofrer, se irão sobreviver e como será a qualidade de vida deles. O abalo emocional prejudica toda a relação, influenciando a família, desde os pais e a criança doente até os irmãos saudáveis (SANTACROCE, 2002), dado que, pela doença, podem ocorrer limitações físicas e alterações na rotina devido aos sinais e sintomas vivenciados, além de hospitalizações que ocasionam ainda ruptura da convivência com familiares (VIEIRA; LIMA, 2002; NASCIMENTO et al., 2005).

Com os avanços no tratamento, os prognósticos têm melhorado acentuadamente em muitos cânceres da infância (LINET et al., 1999; PASTORE et al., 2006). O progresso alcançado no tratamento dos cânceres, a partir do desenvolvimento de técnicas de laboratório que possibilitaram melhor compreensão acerca da biologia molecular e da ressonância magnética, permitiu a separação de tumores que exigem uma terapia mais ou menos agressiva e assim um ganho para 0 planejamento e escolha dos mesmos (TEIXEIRA et al., 2000).

Richardson, Nelson e Meeske (1999) apontam, a partir de estatísticas norteamericanas, um sobrevivente de câncer infantil para cada 900 indivíduos entre 16 e 44 anos de idade. Steuber e Nesbit Jr. (1997) mencionam que a taxa de incidência do câncer infantil, nos EUA, tem crescido em torno de $1 \%$ ao ano, porém inversa ao crescimento da mortalidade, visto que globalmente, a taxa de cura é de $85 \%$ e estima-se para 2010 que a cada 250 adultos, um seja sobrevivente de câncer infantil.

De forma semelhante, no Brasil, o crescente número de curas e maior sobrevida possibilitam que, nesta década, possamos nos deparar com um sobrevivente de câncer infantil para cada 1.000 adultos jovens (CAMARGO; LOPES, 2000). Neste sentido, a presença cada vez maior de crianças sobreviventes de câncer, hoje adultos, traz preocupações quanto aos efeitos tardios dos tratamentos propostos (TEIXEIRA et al., 2000).

Segundo artigo de revisão sobre os efeitos tardios do tratamento do câncer infantil, a maioria das crianças com câncer morria até a década de 70 do século passado, mesmo sendo objetivo a cura a qualquer preço, sem preocupação com os efeitos tardios que eram, até então, desconhecidos. O tempo de observação dos pacientes curados era muito pequeno, o que mudou com o aumento dos casos de sobreviventes, passando a observá-los por vários anos. Assim, após o tratamento, objetivando confirmar a manutenção da remissão da doença e avaliar a toxicidade do tratamento, são realizados exames físicos, laboratoriais e mesmo psicológicos. 
Exemplificando, diante da necessidade emergente, o artigo cita a criação, nos EUA, de um grupo de estudos ("Late Effects Study Group") que tinha como finalidade estudar as experiências dos pacientes curados e as relações entre os tipos propostos de tratamento e as sequelas descritas (LOPES; CAMARGO; BIANCHI, 2000).

Segundo Costa (2005), em seu doutorado, os sobreviventes do câncer infantil apresentam estresse pós-traumático, ansiedade e prejuízo no funcionamento social e na qualidade de vida. Concordando, Mastellaro et al. (2004) mencionam dificuldades escolares, de relacionamentos sociais, familiares e conjugais em sobreviventes do câncer infantil, tornando necessária, para a qualidade de vida dos sobreviventes, a atenção dos profissionais de saúde ainda durante a fase de tratamento da criança.

Complementando, Langeveld et al. (2002), em artigo de revisão de 30 estudos empíricos publicados até o ano de 2001, conduzidos, principalmente, nos EUA, abordando a qualidade de vida de sobreviventes do câncer infantil, observaram que a maioria dos sobreviventes menciona estar com boa saúde e bem psicologicamente, no entanto, também apontam para o risco de déficit de aprendizagem. São reportados ainda dificuldades para conseguir emprego, discriminação no trabalho e menores números de casamentos em sobreviventes do câncer infantil, além da preocupação quanto à capacidade reprodutiva.

Maunsell et al. (2006), objetivando avaliar os efeitos do câncer na infância e adolescência sobre a qualidade de vida de adolescentes e adultos sobreviventes do câncer infantil no Canadá, compararam sobreviventes entre 15 e 37 anos com uma população-controle sem histórico da doença, nas mesmas proporções quanto à idade e ao sexo, por meio de um questionário. Como resultados, obtiveram que o grupocontrole apresentou melhores condições gerais de saúde, visto que os sobreviventes mencionaram mais problemas físicos como os endócrinos, hormonais, cardiovasculares, neurológicos e renais. No entanto, no geral, as diferenças de qualidade de vida, entre os dois grupos, foram pequenas e não importantes clinicamente, o que conferiu um resultado de boa adaptabilidade entre os adolescentes e adultos sobreviventes do câncer infantil no Canadá.

Objetivando identificar, da perspectiva de crianças e adolescentes com câncer entre 5 e 21 anos, questões importantes para a sua qualidade de vida e identificar como eles pensam que poderia ser melhorada a experiência com o tratamento, 
Moody et al. (2006) apresentam, a partir da análise qualitativa de entrevistas em profundidade, quatro grandes temas: solidão, isolamento e perda de uma infância normal; diminuição do prazer pela comida; desconforto físico e incapacidade e, por fim, respostas emocionais para o câncer, especificamente a raiva e o medo. Apontaram, ainda, sugestões para minimizar alguns problemas, como melhorar $\circ$ gosto da comida, decorar de forma mais confortável o hospital e possibilitar atividades sociais com outras crianças de idade semelhante.

Protocolos terapêuticos são desenvolvidos de acordo com o tipo de tumor, a extensão e a própria evolução da doença e estes podem conter as modalidades de cirurgia, quimioterapia, radioterapia ou imunoterapia, adotadas de forma individual ou em associação umas com as outras. Para tanto, uma gama de especialistas é necessária, e o trabalho requer envolvimento de todos, doente, familiares e equipe (BRASIL, 2008c). Dada a complexidade do tratamento, ele deve ser realizado em centros especializados.

A quimioterapia, uma das abordagens terapêuticas para o tratamento do câncer, no caso específico das crianças e adolescentes, é a terapêutica mais frequente, de forma individual ou associada a outras modalidades. No entanto, segundo Koren e Schechter (2007), comparando-se aos estudos com a população adulta, devido à complexidade ética de expor as crianças a testes com novas drogas e ainda devido à baixa incidência, há poucos estudos clínicos ligados aos quimioterápicos e aos efeitos adversos das drogas usadas nos diferentes protocolos para tratamento do câncer infantil.

Dessa forma, procuramos junto à literatura indexada nas bases de dados MEDLINE (National Library of Medicine) e LILACS (Literatura Latino-Americana e do Caribe em Ciências da Saúde), além de vias não sistemáticas, a partir das palavraschave children, adolescents, cancer, chemotherapy e nursing responder ao objetivo aqui proposto: compreender como as crianças e os adolescentes com câncer vivenciam a experiência da quimioterapia. No entanto, os resultados foram de pouca representatividade no que se refere a conhecer a experiência quimioterápica, a partir de relatos das próprias crianças e adolescentes que fazem quimioterapia, o que influenciou e favoreceu a continuidade da busca pela temática aqui proposta. 


\subsection{Particularidades da quimioterapia}

Há relatos de que civilizações antigas do Egito e da Grécia utilizavam sais metálicos como arsênico, cobre e chumbo como drogas, com efeito quimioterápico, no entanto, os registros sobre o tratamento quimioterápico datam do final do século XIX, com a descoberta da solução de Fowler (arsenito de potássio) por Lissaver em 1865 e da toxina da Coley em 1890 (BONASSA, 2005).

A utilização do arsênico possibilitou a observação de atividades antitumorais contra a leucemia e o linfossarcoma. Vale dizer, porém, que as pesquisas para a quimioterapia antineoplásica foram encorajadas a partir da quimioterapia das doenças infecciosas que usou terapeuticamente a casca da chinchona tree, isolando a quinina e a emetina, importantes para o tratamento da malária e da disenteria amebiana (ANELLI; ANELLI, 2000).

Utilizado nas duas grandes guerras mundiais como arma química e investigado pela associação da exposição de soldados (durante a Primeira Guerra Mundial) e de marinheiros (com a explosão de Bari Harbor - Segunda Guerra Mundial), além do desenvolvimento de mielodepressão intensa no grupo de indivíduos contaminados (ANELLI; ANELLI, 2000; BRASIL, 2008d), o gás mostarda despertou investigações. A partir do contrato entre o Office of Scientific Research and Development (OSRD) e o Department of Pharmacology at Yale University, os pesquisadores investigaram a família dos gases relacionados, encorajando as pesquisas com humanos a partir de resultados de regressão temporária de tumores em ratos com o uso da mostarda nitrogenada (KRUEGER, 2004).

Em dezembro de 1942, médicos do New Haven Hospital administraram mostarda nitrogenada a doentes com linfossarcoma avançado, resistentes à radioterapia, e observaram uma regressão intensa e temporária dos tumores destes pacientes (KRUEGER, 2004). No entanto, os resultados foram publicados apenas em 1946, em virtude da natureza secreta do gás mostarda (ANELLI; ANELLI, 2000). A partir desta publicação, dos estudos clínicos com o gás mostarda e com o ácido fólico, um grande avanço foi alcançado na quimioterapia antineoplásica (BRASIL, 2008d).

Em 1947, Sidney Farber, patologista do Boston Children's Hospital, anunciou que tinha alcançado remissão em pequenos grupos de crianças com LLA, publicando, 
em 1948, artigo sobre a capacidade terapêutica da aminopterina na indução da remissão da leucemia aguda em crianças (ANELLI; ANELLI, 2000; KRUEGER, 2004).

Surgiram, ainda, estudos comparando os programas propostos para os tratamentos e a efetividade destes, testando as terapias químicas também em tumores sólidos. Em 1957, foi sintetizado o 5 -fluorouracil (5-FU) que utilizado em altas doses proporcionou regressão em diversos tumores avançados e resistentes a outras terapias. Houve, no entanto, desapontamentos ao observar a toxicidade destas drogas e a limitação da atividade antitumoral, apesar do uso da máxima dose tolerada. Durante os anos 60 do século XX, o 5-FU foi aplicado nos carcinomas de mama, cólon, estômago e pâncreas, após modificação das doses, e desenvolveramse outras drogas relacionadas e novas técnicas de administração, a fim de reduzir a toxicidade e melhorar a efetividade (KRUEGER, 2004).

Ainda na década de 1950 do último século, foram incorporados os compostos da vinca (vimblastina e vincristina). Apesar do grande avanço alcançado com o desenvolvimento das drogas e com a combinação de diferentes quimioterápicos (poliquimioterapia) para a cura das neoplasias (ANELLI; ANELLI, 2000), as pesquisas continuam tanto para o desenvolvimento de novas drogas com maior efetividade quanto para a suavização dos seus efeitos colaterais.

Muitos paradigmas de incurabilidade foram quebrados com o sucesso de alguns agentes quimioterápicos, como a citosina arabinoside (ARA-C) e os antracíclicos que levaram a remissões completas, além de aumentarem a sobrevida e a possibilidade de cura para os casos de LMA. Por anos, apesar do acesso a essas drogas, muitas crianças morreram, até que estudos, principalmente prospectivos, conduzissem às melhores maneiras de manejo destas drogas, mas ainda são necessários investimentos e pesquisas para alcançar maiores índices de cura (PEREIRA, 2006).

Hoje, a quimioterapia antineoplásica, utilizada isolada ou em combinação de diversos agentes químicos, é empregada para destruir as células do câncer. Diferente de outras terapêuticas, possibilita um tratamento sistêmico, tornando possível a cura de diversos tipos de câncer e o tratamento precoce de metástases (BONASSA, 2005). Sua meta, portanto, é a redução do tamanho do tumor primário, destruição das células cancerígenas e prevenção de metástases (ALCOSER; RODGERS, 2003; BONASSA, 2005). As drogas quimioterápicas atuam nas diversas fases do ciclo celular, diretamente 
interligadas com a replicação do DNA da célula tumoral, objetivando a morte celular ou a garantia de não divisão da célula neoplásica (SILVA; ALMEIDA, 2000). Atuam, portanto, em células de rápida proliferação, não distinguindo células normais e saudáveis das células cancerígenas, o que causa inúmeros efeitos colaterais ou tóxicos que, desta forma, necessitam de monitorização (ALCOSER; RODGERS, 2003; BONASSA, 2005).

A quimioterapia, indicada na maioria dos casos de tumores infantis, associada ou não à radioterapia e à cirurgia, é um tratamento geralmente longo, com duração de aproximadamente um ano e meio a dois anos (HAAGEDOORN et al., 2000), a depender do protocolo instituído. A quimioterapia tem melhor resposta quando utilizada no câncer infantil do que em adultos, pois a maioria dos cânceres pediátricos é quimiossensível (BONASSA, 2005; THOMPSON, 2003).

Comumente usada em neoplasias malignas, pode ser empregada como quimioterapia de indução ou neoadjuvante (antes da cirurgia), a qual almeja redução do tumor e cirurgias mais conservadoras; adjuvante (após o tumor primário ter sido controlado por cirurgia ou radioterapia) com o objetivo de erradicar micromestástases e terapêutica (quimioterapia como a principal forma de tratamento) (ANELLI; ANELLI, 2000; BONASSA, 2005).

Com mais de 100 drogas quimioterápicas, as vias de administração são as mais diversas: oral, subcutânea, intramuscular, endovenosa, intratecal, intravesical, intra-arterial, intracavitária (pleura abdominal), tópica e intrarretal. Em crianças e adolescentes, no entanto, as principais vias utilizadas são a endovenosa, subcutânea, intramuscular, oral e intratecal (BONASSA, 2005). A via endovenosa é a mais utilizada, pela sua maior segurança quanto à absorção e nível sérico, sendo necessário, para um acesso venoso seguro, por exemplo, cateteres de curta ou longa permanência (SILVA; ALMEIDA, 2000).

O emprego de drogas citostáticas tem possibilitado a cura na minoria dos casos para o tratamento de doenças disseminadas, no entanto, tem bons resultados quando utilizadas em doenças hematológicas malignas como leucemia e linfomas, cânceres pediátricos de maneira geral, alguns tumores sólidos em adultos, câncer testicular em homens e coriocarcinoma em mulheres, além do seu uso indicado para o tratamento paliativo e/ou prolongamento da vida (HAAGEDOORN et al., 2000). 
Introdução

Os agentes quimioterápicos são escolhidos para o tratamento a partir da sua sensibilidade com as diferentes doenças, da capacidade de administração (isolados ou em associações) e da toxicidade que podem representar (DOROSHOW, 2006).

Dessa forma, segundo Bonassa (2005), as drogas quimioterápicas podem ser classificadas de duas maneiras principais, uma de acordo com a estrutura química e a função em nível celular (seis grupos) e outra de acordo com a especificidade no ciclo celular (dois grupos). Tais classificações podem ser observadas nos quadros a seguir:

Mostardas nitrogenadas (mecloretamina e ciclofosfamida), derivados etilenomímicos

Agentes alquilantes (tiotepa), alquil-sulfonatos (bussulfano), triazina (dacarbazina), nitrosureias (carmustina, lomustina e stretozocin) e sais metálicos (cisplatina e carboplatina)

Análogos do ácido fólico (metotrexato), Antimetabólitos análogos das purinas (mercaptopurina e tioguanina) e análogos das pirimidinas (citarabina e fluorouracil)

\begin{tabular}{cc}
\hline Antibióticos antitumorais & $\begin{array}{c}\text { Dactinomicina, doxorrubicina, } \\
\text { daunorrubicina, bleomicina, mitomicina, } \\
\text { idarrubicina e mitoxantrona }\end{array}$ \\
\hline \hline Hormônios e antagonistas hormonais & $\begin{array}{c}\text { Procarbazina, hidroxiureia, asparaginase, } \\
\text { estramustine, octreotida, }\end{array}$ \\
\hline \hline Estrogênios, antiestrogênios, \\
$\begin{array}{c}\text { antiandrogênios, progestogênios, análogos } \\
\text { Ledrenocorticosteroides inibidores dos } \\
\text { adrenocorticosteroides (incluindo os } \\
\text { inibidores da aromatase) e outros }\end{array}$ \\
\hline \hline Plantas alcaloides & $\begin{array}{c}\text { Inibidores mitóticos (vincristina, vimblastina e } \\
\text { paclitaxel) e inibidores da topoisomerase } \\
\text { (topotecano, irinotecano, etoposide e } \\
\text { teniposide) }\end{array}$ \\
\hline \hline
\end{tabular}

Fonte: BONASSA, 2005

Quadro 3 - Classificação dos quimioterápicos, de acordo com a estrutura química e função em nível celular (similaridade de ação) 
Classificação das drogas

Ciclo celular específico

Ciclo celular não específico
Grupo de drogas quimioterápicas

Antimetabólitos, alcaloides da vinca

Alquilantes, antibióticos antitumorais

Fonte: BONASSA, 2005

Quadro 4 - Classificação dos quimioterápicos, de acordo com a especificidade no ciclo celular

Os agentes alquilantes estão entre os mais usados na terapia antineoplásica. Ligam-se ao DNA impedindo a replicação das células tumorais, ao atuarem em todas as fases do ciclo celular (DOROSHOW, 2006). Os principais efeitos colaterais relacionados a este grupo estão ligados ao sistema hematopoiético (leucopenia), gastrintestinal (náuseas e vômitos), reprodutor (oligo ou azoospermia e amenorreia) e alopecia, além de efeitos ainda mais intensos, a depender da dosagem e da medicação administrada, como dermatite, hiperpigmentação da pele, flebite no trajeto dos vasos, cistite hemorrágica, necrose miocárdica e outros (BONASSA, 2005).

Os antimetabólicos são drogas altamente eficazes, usadas de forma generalizada nos esquemas curativos para tratamentos de neoplasias infantis (DOROSHOW, 2006). Os principais efeitos colaterais são mielodepressão (leucopenia e trombocitopenia), toxicidade gastrintestinal (náuseas, vômitos, diarreia e mucosite) e a alopecia. Há drogas, ainda neste grupo, relacionadas a quadros de disfunção hepática (BONASSA, 2005).

Os antibióticos antitumorais são um grupo de compostos antimicrobianos que impedem a duplicação e separação das cadeias de DNA e RNA. Os efeitos colaterais estão relacionados ao trato gastrintestinal (náuseas, vômitos, estomatite, anorexia e diarreia) e ao sistema hematológico (leucopenia e trombocitopenia). Algumas drogas podem ainda apresentar cardiotoxicidade e toxicidade pulmonar, além de alopecia e necrose tecidual diante da ocorrência de possíveis extravasamentos das drogas vesicantes (BONASSA, 2005).

O grupo das plantas alcaloides, como em outros, possui efeitos colaterais diversos, a depender da droga e da dosagem utilizada, o que leva a avaliar os possíveis efeitos colaterais individualmente e não apenas em relação ao seu grupo. 
Como exemplo, temos neste grupo, drogas mielodepressoras contrastando com a vincristina que poupa a medula óssea. Outros efeitos adversos encontrados com o uso de drogas do grupo das plantas alcaloides são neurotoxicidade, alopecia, estomatite, febre, hipotensão, eritema cutâneo generalizado, reação anafilática, mielotoxicidade, diarreia e dispneia (BONASSA, 2005).

Os agentes múltiplos possuem mecanismos de ação, características e toxicidades diferentes entre si, incluindo, entre as diversas drogas do grupo, neurotoxicidade, hepatotoxicidade, náuseas, vômitos e eritema cutâneo generalizado (BONASSA, 2005).

Por fim, os hormônios e antagonistas hormonais dependem de receptores hormonais nas células tumorais. Dificilmente promovem a cura, mas eles podem retardar o crescimento do tumor sem gerar citotoxicidade, além de aliviar sintomas como a dor. Possuem efeitos colaterais específicos para cada droga, incluindo, náuseas, anorexia, alterações da libido, ginecomastia, sangramento uterino, hipertensão, alterações tromboembólicas, cefaleias, agravamento de distúrbios cardiocirculatórios, impotência, mialgia, disfunção hepática, galactorreia, alterações do ciclo menstrual, fogachos, edemas, depressão e irritabilidade (BONASSA, 2005).

Em outra esfera, as drogas, tal como mencionado, podem ser divididas segundo a especificidade de ação no ciclo celular. Assim, aquelas classificadas como ciclo celular específicas combatem ativamente as células de determinada fase do ciclo celular, sendo notadamente efetivas no tratamento de tumores com grande número de células em processo de divisão rápida. Já as drogas do ciclo celular não específicas agem sobre as células em qualquer fase, necessitando, para sua ação, apenas da divisão celular e não de altas taxas de crescimento. Assim, doses maiores geram maiores danos às células (BONASSA, 2005).

A quimioterapia, tal como observamos, influencia os doentes em diversos âmbitos, afetando aspectos físicos, emocionais e sociais, além dos familiares que se adequam às necessidades do tratamento a fim de promover a sua realização.

Dessa forma, a partir da grande interferência da doença sobre a vida do doente e de seus familiares, questões relacionadas com a qualidade de vida vêm se apresentando como uma das prioridades nos textos analisados. Neste sentido, a visão do doente torna-se importante e deve ser considerada, visto que ele é o 
principal conhecedor de suas necessidades relacionadas com bem-estar e valores humanos. O impacto do tratamento é, assim, considerado em sua qualidade de vida, possibilitando, com uma avaliação regular da satisfação do doente, focar os pontos importantes para ele e melhorar a assistência nas diferentes dimensões: física, psicológica, social e de reabilitação (VENTAFRIDDA et al., 2006).

Concordando, Lopes, Camargo e Bianchi (2000) referem que a qualidade de vida é afetada pela doença e pelo tipo de tratamento, e este atinge de diferentes formas a vida das crianças e dos adolescentes e de seus familiares, podendo gerar efeitos psicológicos secundários, déficits neuropsicológicos, alterar o desempenho nas atividades da vida diária, o planejamento familiar e até a concentração e o estado emocional.

Apesar de muitas definições sobre qualidade de vida, os autores concordam ser esta, um fenômeno subjetivo. Para ○ Grupo de Qualidade de Vida da Organização Mundial da Saúde (OMS), qualidade de vida é definida como "a percepção do indivíduo de sua posição na vida no contexto da cultura e do sistema de valores nos quais ele vive e em relação a seus objetivos, expectativas, padrões e preocupações". Na qualidade de vida, devem-se considerar as esferas social, psicológica, espiritual, ocupacional e física, numa visão multidimensional da saúde, além de uma definição operacional ligada à avaliação da saúde, a partir do que o indivíduo acredita ser possível ou ideal (VENTAFRIDDA et al., 2006, p.836).

A família, segundo Mitchell (2007), em estudo realizado no Reino Unido com nove enfermeiros e 19 adultos com câncer submetidos à quimioterapia, é tida como uma fonte de suporte, mas também necessita de suporte pela vivência ao lado da pessoa doente, visto as mudanças no cotidiano e mesmo nas relações entre os membros, tanto com o cônjuge quanto com as crianças. Os indivíduos que realizam a quimioterapia mencionam ainda os problemas relacionados com o sono e a fadiga, além de perda da concentração e da memória.

O estudo evidencia que os sintomas comuns de angústia social e emocional decorreram da busca pela normalidade, onde os indivíduos manifestavam o desejo pelo retorno da normalidade ou pelo menos pela preservação do grau de normalidade que ainda detinham, normalidade esta indicativa da realização de atividades que desempenhavam no dia a dia, rotinas e trabalhos (MITCHELL, 2007). 
Num estudo europeu, a partir de entrevistas com adultos com câncer, cujo objetivo era entender o que é viver com o diagnóstico de câncer, os participantes referiam que, apesar de se sentirem satisfeitos com o tratamento médico, sentiam que poderiam ter algum programa para o cuidado de suas necessidades psicossociais. Mencionaram que os serviços de saúde não proporcionaram condições para que eles pudessem falar sobre suas experiências e sentimentos. Os pacientes informaram, ainda, a necessidade de falar sobre suas preocupações, pois mesmo com o suporte das famílias, eles também perceberam que os familiares sofreram por causa deles. Quanto ao período de tratamento, destacaram as dificuldades com relação aos sintomas, complicações e viagens. Sentiram o desgaste físico e mental, além de viverem de forma estressante o período de check-ups devido à ameaça de um novo câncer (SAEGROV; HALDING, 2004).

Segundo Wright et al. (2002), em estudo europeu realizado a partir de entrevistas com adultos com câncer, em todas as fases da doença, objetivando descrever, avaliar e categorizar os problemas sociais vivenciados, diversos temas foram levantados, sendo eles relacionados às tarefas domésticas, questões financeiras, emprego, relacionamentos, sexualidade, imagem corporal, recreação e outros. Reportaram, ainda, mais itens de problemas sociais em grupos femininos, de pacientes mais jovens e de grupos que realizam tratamento paliativo, quando comparados com outros grupos de doentes com câncer.

Considerando, portanto, que a quimioterapia é fonte de preocupações, questionamentos e dúvidas tanto por parte das crianças quanto de seus familiares, dado que está associada a efeitos colaterais físicos e psicológicos (COSTA; LIMA, 2002; VALLE; FRANÇOSO, 1992), o objetivo do presente estudo é compreender como as crianças e os adolescentes com câncer vivenciam a experiência da quimioterapia, a partir de seus próprios relatos.

Dessa forma, conhecer as demandas e sentimentos vivenciados pelas crianças e adolescentes e incorporá-los no plano de cuidados possibilitará uma assistência qualificada e dirigida à qualidade de vida da criança, do adolescente e de sua família. 
PERCURSO METODOLÓGICO 


\subsection{Caracterização do estudo}

O presente estudo, de natureza exploratória, busca, além de observar e descrever, investigar a natureza do fenômeno aqui estudado e a maneira pela qual é manifestado (POLIT; BECK, 2004). Dados o objeto e o objetivo do estudo, nos apoiamos na abordagem qualitativa, visto que a experiência humana, referida pelo próprio sujeito é capaz de fundamentar o conhecimento sobre os indivíduos (POLIT; HUNGLER, 1995). Tal opção é ainda justificada por ser esta abordagem valiosa, quando se procura descobrir e entender o significado de eventos, práticas sociais, percepções e ações dos indivíduos (BOGDAN; BIKLEN, 1994). A pesquisa qualitativa busca estudar o fenômeno e "entender seu significado individual ou coletivo para a vida das pessoas", significado este estruturante, já que em torno deste as pessoas organizam suas vidas e o próprio cuidado com a saúde (TURATO, 2005, p. 509), além de permitir compreender a complexidade de emoções, valores e atitudes (MINAYO, 2007).

Vale ressaltar que as investigações de natureza qualitativa têm a finalidade de explorar, compreender e explicar um fenômeno, a partir de dados e não de teorias e conhecimentos formalizados; têm o propósito de nos ajudar a dar sentido ao mundo de um modo específico (MORSE; RICHARDS, 2002) e de "qualificar através dos olhos dos participantes ao invés de quantificar através dos olhos do observador" (MOREIRA; CALEFFE, 2006, p. 67).

\subsection{Considerações éticas}

Em observância à legislação que regulamenta a pesquisa com seres humanos (BRASIL, 1996), encaminhamos o protocolo de pesquisa ao Comitê de Ética em Pesquisa do Hospital das Clínicas da Faculdade de Medicina de Ribeirão Preto da Universidade de São Paulo (HCFMRP - USP) e o mesmo, após análise, foi aprovado (Processo HCRP n. 2399/2008 - Anexo 1). 
Elaboramos o documento "Termo de Consentimento Livre e Esclarecido" (APÊNDICE I), no qual em linguagem simples as crianças, os adolescentes e seus responsáveis foram informados sobre o objetivo da pesquisa, os procedimentos, a garantia do anonimato e respeito ao desejo ou não de participar do estudo.

Após explicação e discussão do documento "Termo de Consentimento Livre e Esclarecido" daqueles que concordaram em participar, foi solicitada a anuência mediante assinatura do termo. Nesta ocasião também foi solicitada autorização, para que a entrevista fosse gravada. Vale destacar que tal consentimento foi autorizado pela criança ou adolescente e seu responsável como recomendado pela Resolução 196/96 do Conselho Nacional de Saúde (BRASIL, 1996).

\subsection{Local do estudo}

A instituição selecionada para o estudo foi um hospital-escola, referência para a assistência em Oncopediatria, situado no interior do Estado de São Paulo - Hospital das Clínicas da Faculdade de Medicina de Ribeirão Preto da Universidade de São Paulo (HCFMRP - USP). O serviço de Oncopediatria recebe crianças e adolescentes para acompanhamento em unidades de internação e ambulatorial e conta, ainda, com laboratórios e serviços especializados. O tratamento quimioterápico ocorre na unidade de internação, situada no $7^{\circ}$ andar do hospital em questão (campus universitário) e na Central de Quimioterapia, no $2 \%$ andar (ambulatório).

A unidade de internação pediátrica direcionada à oncologia possui nove leitos, distribuídos em quatro enfermarias. A Central de Quimioterapia, por sua vez, com funcionamento de $2^{\mathrm{a}}$ a $6^{\mathrm{a}}$ feira, das $8: 00$ às $17: 00$ horas, conta com 11 poltronas em uma sala coletiva para administração de quimioterápicos e três leitos em quartos reservados, não há distribuição de espaços entre adultos e crianças de forma sistematizada. 


\subsection{Inserção no campo empírico}

Nossa inserção no campo empírico (Enfermaria e Central de Quimioterapia) iniciou-se após a aprovação do protocolo de pesquisa. Ainda, como parte desta fase, participamos das reuniões da equipe multidisciplinar do Serviço de Oncopediatria, realizadas mensalmente nas primeiras quartas-feiras do mês e das reuniões clínicas semanais, toda quarta-feira, momento no qual se discutiam os casos de crianças e adolescentes internados na enfermaria em questão.

Estas atividades ofereceram oportunidades de aproximação com a equipe de saúde e com a dinâmica do processo de trabalho, além de possibilitar a familiaridade com a terminologia da equipe e a aquisição de conhecimento na área do câncer infanto-juvenil. Possibilitou, ainda, o reconhecimento dos potenciais participantes do estudo. Esta etapa foi de fundamental importância para o sucesso da fase de coleta de dados, pois, pelas particularidades dos participantes, o vínculo com o pesquisador foi condição necessária.

Considerando que as crianças em início do tratamento realizam a quimioterapia internadas e, a depender de suas condições clínicas, são transferidas para a Central de Quimioterapia, realizando o procedimento ambulatorialmente, justificamos a coleta de dados nos dois setores.

\subsection{Participantes do estudo}

Participaram do estudo crianças e adolescentes (dos oito aos 18 anos) com os mais diversos tipos de câncer em qualquer etapa do tratamento quimioterápico, realizado na Central de Quimioterapia ou na Enfermaria de Oncopediatria do HCFMRP - USP.

Nossa opção foi por crianças e adolescentes nesta faixa etária, pois segundo Faux, Walsh e Deatrick (1988), nestas idades elas possuem habilidades para comunicação não verbal e conseguem compreender e expressar seus sentimentos 
verbalmente, em função do estágio de desenvolvimento em que se encontram. Thompson (2003) afirma que crianças entre sete e 12 anos de idade necessitam de explicações mais completas e detalhadas, pois elas irão preencher os vazios do seu conhecimento com fantasias. Segundo o autor, é provável ainda que tais crianças se interessem em aprender sobre a doença, o tratamento e aspectos científicos do câncer, visto a fase de desenvolvimento cognitivo no qual se encontram.

Dessa forma, nos posicionamos contrárias à crença de que as crianças e os adolescentes são pouco competentes para narrar suas experiências, o que tem levado seus pais ou responsáveis a serem seus informantes. Faux, Walsh e Deatrick (1988) e Blarison (1991) consideram que as crianças são as melhores fontes de informação sobre o que ocorrem com elas mesmas.

Para a seleção dos participantes do estudo, utilizamos, no caso da Central de Quimioterapia, a listagem semanal das crianças e adolescentes que realizariam quimioterapia, disponibilizada pela equipe. De posse de tal lista, na qual constavam informações como nome, registro, idade, diagnóstico, protocolo e o dia da realização da quimioterapia, selecionamos aqueles que atendiam ao critério idade (faixa etária de sete a 18 anos). Para crianças e adolescentes internados no setor de Oncologia Pediátrica, foi feita consulta diária no serviço, buscando aqueles que preenchiam os critérios de inclusão (idade e em procedimento quimioterápico). Foram excluídos da pesquisa apenas as crianças e os adolescentes desta faixa etária que não desejaram participar da pesquisa ou que não estivessem em condições físicas e/ou psicológicas de participar.

Após identificação dos pacientes que atendiam tais critérios, foi necessário o estabelecimento do vínculo entre o pesquisador e o participante do estudo e sua família para só então ser apresentado a eles o convite para participarem do estudo. A aproximação com as crianças e os adolescentes ocorreu de diferentes formas, a depender das reações das mesmas, seja pelas conversas informais e visitas frequentes, seja pela realização de atividades lúdicas (jogos como jogo da memória, jogos com cartas de baralho, xadrez, atividades de pintura ou ainda um jogo de completar espaços previamente programados pelos participantes com as escolhidas letras do alfabeto, chamado "STOP"). 
Posteriormente, para aqueles que concordaram em participar foi, então, apresentado e discutido o Termo de Consentimento Livre e Esclarecido, com a assinatura dos mesmos ao final.

Conforme o observado durante o início do trabalho de campo, as entrevistas ocorreram em períodos entre os ciclos quimioterápicos ou imediatamente antes da infusão, visto que, durante o processo de administração da quimioterapia, as crianças e os adolescentes mostram-se menos responsivos, com indisposição para vínculos, pesquisas ou outras interações devido aos efeitos decorrentes da infusão das drogas.

Os participantes do estudo foram entrevistados individualmente e, conforme sua preferência, com ou sem a presença dos responsáveis, no entanto, quando presentes, vale destacar que a entrevista foi direcionada à criança ou ao adolescente.

Quanto aos locais de realização da entrevista, estas aconteceram nas enfermarias onde estavam internados, na Central de Quimioterapia ou nos corredores destinados à espera dos pacientes pelas consultas médicas, locais onde comumente apresentam-se receptivos e animados, com grande aceitação das atividades lúdicas.

De acordo com os critérios de inclusão, foram listados 15 crianças e adolescentes, no entanto, 5 deles não aceitaram participar do estudo, mesmo após a criação do vínculo com a pesquisadora. Parece-nos que os motivos para a recusa estiveram ligados à timidez e, assim, ao desejo de não se expressarem de forma verbal diante de uma entrevista, por mais informal que esta pudesse parecer. Acrescentamos, ainda, a partir do convívio com os sujeitos, a não participação como reflexo de um período ainda não totalmente aceito, período este de grande angústia e rejeição da situação que vinha, pouco a pouco, sendo trabalhada por eles.

A fim de entender o que desejavam expressar sobre o tema em questão e obter uma figura mais completa da experiência, três participantes foram submetidas a mais de uma entrevista. A partir da ausência de novos conteúdos representativos e com a repetição de informações já levantadas, a continuidade da pesquisa se deu até percebermos a saturação dos relatos. Segundo Minayo (2007), o critério de saturação é atingido no momento em que o pesquisador, pelos dados obtidos em campo, consegue compreender a lógica do grupo em questão, não sendo determinante o número de sujeitos da amostra. 
Dessa forma, participaram do estudo, 10 crianças e adolescentes com idade entre oito e 18 anos, dado que com estas foi possível obter subsídios para a compreensão do fenômeno em questão. Realizamos, em contrapartida, um total de 13 entrevistas.

\subsection{Procedimentos para coleta e registro dos dados}

Para a coleta dos dados empíricos, realizada durante todo o segundo semestre de 2008, utilizamos como instrumento a entrevista semiestruturada (BOGDAN; BIKLEN, 1994) a qual foi gravada para posterior transcrição na íntegra. A opção por esta técnica ocorreu por ela possibilitar o acesso a dados descritivos na linguagem do próprio sujeito e por possibilitar que o pesquisador desenvolva, interativamente, uma ideia sobre a maneira como os sujeitos interpretam aspectos do mundo (POLIT; HUNGLER, 1995). As entrevistas possibilitam, ainda, o mapeamento de práticas, crenças e valores, permitindo a coleta de informações sobre o modo como os sujeitos percebem a realidade que vivenciam e como esta the significa, compreendendo a lógica que ali se encontra (DUARTE, 2004).

Segundo Bogdan e Biklen (1994), na entrevista, a partir de um esquema básico, o entrevistador tem liberdade para adaptações, buscando fugir de respostas puramente afirmativas ou negativas. Nossa opção foi pela entrevista semiestruturada, pois nesta modalidade "as questões seguem uma formulação flexível e a sequência e minuciosidade ficam por conta do discurso dos sujeitos e da dinâmica que acontece naturalmente" (BIASOLI-ALVES, 1998, p.145).

A entrevista (APÊNDICE II) constou de duas partes: a primeira com informações sobre identificação dos participantes da pesquisa como idade, sexo, escolaridade, procedência, diagnóstico e protocolo terapêutico, particularmente relacionado à quimioterapia. A segunda, com questões norteadoras almejando possibilitar o entendimento do processo de doença e o tratamento vivenciado pela criança ou adolescente, incluindo questões que solicitavam ao participante contar a sua história com a doença e com o tratamento, mencionar o que é a quimioterapia, o que sente 
ao se submeter a ela, o que lhe incomoda durante o tratamento, o que mudou em sua vida, o que pensa sobre todo o processo de doença vivenciado, pensamentos sobre o futuro e o que poderia ser diferente.

As entrevistas não foram agendadas previamente. A decisão em realizá-la em determinado momento dependia exclusivamente do vínculo já estabelecido com os sujeitos e da disposição demonstrada pela criança ou adolescente. Realizadas, o tempo médio de duração das entrevistas foi de 30 minutos, porém, os encontros duravam maior tempo a depender das condições da criança e do adolescente, variando entre uma e duas horas, já que antes ou mesmo depois da entrevista, conversávamos e até brincávamos com alguns jogos, tal como mencionado. Nesse tempo de interação, também contava com a presença do responsável pela criança ou adolescente, o que tornou possível conversar com eles sobre a experiência que vivenciavam e entender melhor todo o processo, além de observar as suas reações, enquanto aguardavam consultas e procedimentos ou se submetiam a eles.

Para completar os dados da primeira parte do instrumento de coleta de dados, recorremos aos prontuários das crianças e dos adolescentes com a finalidade de conhecer os registros exatos sobre os protocolos adotados, as datas relacionadas com diagnósticos e mudanças de tratamentos e as possíveis intercorrências.

A observação, outra técnica utilizada, objetivou descrever, de forma livre, questões que julgamos ser necessário acrescentar às informações obtidas com a entrevista, visando a atingir os objetivos almejados pela pesquisa. Dessa forma, foram feitas observações sobre as conversas informais e com relação a como se portam as crianças e adolescentes ao chegarem na unidade, ao aguardarem a intervenção, ao se submeterem aos procedimentos e, após os mesmos, ou seja, como vivem o processo (APÊNDICE III). A observação foi registrada imediatamente ao final do encontro, em um diário de campo, esperando, com isso, melhor entendimento dos relatos, dando atenção especial à comunicação não verbal. Segundo Minayo (2007), no diário de campo, devem ser registradas as impressões pessoais que resultam das conversas informais e dos comportamentos observados, para posteriormente serem utilizados como elementos para a análise dos dados, dando mais veracidade às interpretações. 
Dessa forma, utilizamos essas informações para um melhor entendimento do verdadeiro significado presente nos relatos. Ressaltamos, ainda, que também foram consideradas as informações concedidas pelos responsáveis, visto que o conhecimento do contexto em que estão inseridos é fundamental para a interpretação dos depoimentos. Tal como observamos, muitas vezes eles nos auxiliaram, após a finalização da entrevista com as crianças e adolescentes, dando maiores detalhes e complementando a descrição das ações e reações dos sujeitos diante do processo quimioterápico.

\subsection{Organização e análise dos dados}

Para identificarmos os participantes do estudo, tal como demonstrado entre parênteses após os trechos dos seus respectivos depoimentos, foi utilizada, antes da idade da criança ou adolescente, uma letra do alfabeto, de "A" a "J", de acordo com a ordem em que as entrevistas ocorreram.

Em seguida, a análise dos dados foi feita de forma minuciosa, haja vista que não é tarefa banal, mas complicada que exige extremo cuidado com a interpretação (DUARTE, 2004).

Iniciamos com a ordenação dos dados, mediante a transcrição integral dos depoimentos (117 páginas) complementados com dados obtidos no prontuário e nos registros do diário de campo. Ao transcrever, utilizamos aspas duplas (") para iniciar e encerrar trechos de depoimentos das crianças e adolescentes e aspas simples (') no interior destes para representar as falas de pessoas mencionadas pelos próprios sujeitos do estudo. Na sequência, foi realizada a leitura do material empírico e para tornar os relatos mais compreensíveis para o leitor, foram corrigidos erros grosseiros da língua portuguesa, assim como excluídos trechos repetitivos, sem, no entanto, alterar o significado ou particularidade dos relatos.

A partir de então, organizamos o material em unidades ou "núcleos de significado", compostas por segmentos dos relatos com significados específicos. Cada conjunto de dados (entrevista, apontamentos do diário de campo e dados do 
prontuário) foi analisado parte por parte, sem perder de vista o conjunto. Neste processo, buscamos ultrapassar a mera descrição, pois a partir de uma abstração de maior nível, estabelecendo conexões e relações, é possível a proposição de novas interpretações (BOGDAN; BIKLEN, 1994).

A técnica de análise de conteúdo, utilizada neste estudo, é definida como um "conjunto de técnicas de análise das comunicações visando obter, por procedimentos sistemáticos e objetivos de descrição do conteúdo das mensagens, indicadores (quantitativos ou não) que permitem a inferência de conhecimentos relativos às condições de produção/recepção (variáveis inferidas) destas mensagens" (BARDIN, 2004, p.37).

Seguimos as orientações de Gomes (2007) que estabelece os seguintes passos: pré-análise (leitura do material empírico buscando mapear os sentidos atribuídos pelos sujeitos às perguntas feitas); análise dos sentidos expressos e latentes (com a finalidade de identificar os núcleos de sentidos, ou seja, eixos em torno dos quais as ideias gravitam); elaboração de temáticas que sintetizam o material empírico e análise final (discussão das temáticas).

Em concordância com Gomes (2007), nossa opção foi por não analisar estatisticamente o material, conforme preconizado originalmente pela técnica, mas por trabalhar de maneira interpretativa o conjunto de conteúdos e enunciados, buscando descobrir o que está por trás dos conteúdos manifestos, superando as aparências do que está sendo comunicado. 
RESULTADOS E DISCUSSÃO 


\subsection{CARACTERIZAÇÃO DAS CRIANÇAS E DOS ADOLESCENTES}

Participaram do estudo 10 crianças e adolescentes com idades entre oito e 18 anos, predominando a faixa etária entre 15 e 18 anos, com sete deles. Os diagnósticos foram os mais diversos, porém, todos realizavam, conforme critério de inclusão, tratamento quimioterápico no período do estudo. Vale ressaltar que não foi admitida a mesma fase de tratamento para todos os participantes, o que permitiu que tivéssemos crianças e adolescentes nas diversas fases do tratamento quimioterápico, desde iniciantes, como no exemplo vivenciado no segundo ciclo, até adolescentes realizando fases de manutenção ou de recidiva da doença.

Dados do Registro de Câncer da cidade de São Paulo, entre os períodos de 1969 a 1998, indicam que as leucemias estavam entre as neoplasias mais comuns da infância, com cerca de 30\% dos casos. Representando 15\% dos cânceres infantis estavam as neoplasias do SNC. Quanto aos tumores ósseos malignos, como o osteossarcoma e $\circ$ sarcoma de Ewing, tivemos aproximadamente $14 \%$ das representações e, em seguida, com 10\% de incidência, o grupo de linfomas, representados pelo Linfoma de Hodgkin e não Hodgkin, sendo este último, quatro vezes mais frequente que o Linfoma de Hodgkin. Aparecem ainda os grupos de sarcomas de partes moles, carcinomas e neoplasias malignas epiteliais, tumores renais com 6\%, tumores do sistema nervoso simpático, tumores de células germinativas e gonadais, retinoblastoma com $3 \%$ e tumores hepáticos com cerca de $1 \%$ (MIRRA; LATORRE; VENEZIANO, 2004).

Os diagnósticos mais frequentes entre os participantes do nosso estudo foram três adolescentes com Linfoma de Hodgkin, dois com Leucemia Mieloide Aguda e um com Leucemia Linfoide Aguda, seguidos, igualmente, com um adolescente com cada tipo aqui representado de Germinoma de Pineal, Osteossarcoma, Linfoma não Hodgkin e Sarcoma de Ewing.

Vale mencionar que as diferenças percentuais de diagnóstico apresentadas no estudo diferem das estatísticas disponibilizadas pela literatura, o que pode ser explicado pela baixa representatividade, em termos quantitativos, de números de sujeitos, fato que não foi estabelecido como critério do nosso estudo. 
Com relação ao câncer infantil segundo o sexo, há ainda, de acordo com a literatura, um predomínio de tumores infantis, na maioria dos países, em meninos (MIRRA; LATORRE; VENEZIANO, 2004). Da mesma forma, temos $60 \%$ dos entrevistados do sexo masculino.

No levantamento de dados dos sujeitos da pesquisa identificamos o local de origem dos participantes, sendo apenas três da cidade de Ribeirão Preto, local do estudo. Os demais são procedentes de cidades da região ou mesmo de outros estados, tendo em vista que o HCFMRP-USP é, tal como mencionado anteriormente, centro de referência para o tratamento do câncer infantil.

Por necessitar de acompanhamento de um responsável em todas as etapas do tratamento, muitas vezes, é necessária uma reestruturação da família no que diz respeito ao trabalho, com abandono do mesmo, geralmente pela mãe. Assim, no nosso estudo, observamos que seis das mães trabalhavam antes da doença do filho, mas, em decorrência desta, deixaram o emprego.

Identificamos que algumas atividades que as crianças e os adolescentes realizavam antes do diagnóstico de câncer foram interrompidas devido ao tratamento, pois antes da doença, nove participantes estavam estudando, sendo que um estudava e trabalhava e um apenas trabalhava. Com o tratamento, todos os participantes sofreram interrupção dos estudos, e os dois adolescentes que trabalhavam também deixaram de trabalhar. Observamos que a interrupção, de forma brusca, altera o cotidiano das crianças, dos adolescentes e de seus familiares.

$\mathrm{Na}$ caracterização dos participantes do estudo, foram avaliados o tempo de diagnóstico e o tratamento. Observamos que um deles foi diagnosticado no segundo semestre de 2006, um no final do segundo semestre de 2007, três no primeiro semestre de 2008 e três no segundo semestre de 2008. Com relação às recidivas, uma foi diagnosticada no primeiro e outra no segundo semestre de 2008.

Os tratamentos foram, conforme mencionado, quimioterapia (QT) em todos os casos, associada à cirurgia em quatro e radioterapia (RT) em dois casos. O número de realização de ciclos quimioterápicos variou de 2 a 14, incluindo aqueles decorrentes das recidivas.

As crianças e adolescentes utilizaram diversos protocolos para o tratamento quimioterápico. Dividimos, dessa forma, as drogas quimioterápicas utilizadas junto a 
estes participantes segundo sua especificidade no ciclo celular. Ciclo celular específico: asparaginase, bleomicina, citarabina, daunorrubicina, doxorrubicina, etoposido, mercaptopurina, metotrexato, tioguanina e vincristina. Ciclo celular não específico: carboplatina, ciclofosfamida, cisplatina, dacarbazina, ifosfamida e procarbazina.

A fim de sintetizar os dados relativos à caracterização das crianças e adolescentes participantes do estudo, apresentamos o quadro a seguir: 


\begin{tabular}{|c|c|c|c|c|c|c|c|c|c|c|}
\hline & A. & B. & C. & D. & E. & F. & G. & H. & I. & J. \\
\hline Idade & 16 anos & 13 anos & 11 anos & 8 anos & 15 anos & 17 anos & 15 anos & 16 anos & 17 anos & 18 anos \\
\hline Sexo & Masculino & Masculino & Feminino & Feminino & Masculino & Masculino & Feminino & Masculino & Feminino & Masculino \\
\hline Escolaridade & $\begin{array}{c}\text { 10 ano do } \\
\text { ensino } \\
\text { médio } \\
\end{array}$ & $\begin{array}{c}8^{\mathrm{a}} \text { série do } \\
\text { ensino } \\
\text { fundamental }\end{array}$ & $\begin{array}{l}\text { 6ㅁ série do } \\
\text { ensino } \\
\text { fundamental }\end{array}$ & $\begin{array}{c}2^{\mathrm{a}} \text { série do } \\
\text { ensino } \\
\text { fundamental }\end{array}$ & $\begin{array}{l}\text { 1ำ ano do } \\
\text { ensino médio }\end{array}$ & $\begin{array}{l}1 \text { o ano do } \\
\text { ensino médio }\end{array}$ & $\begin{array}{c}\text { 10 ano do } \\
\text { ensino } \\
\text { médio }\end{array}$ & $\begin{array}{l}1 \text { ㅇ ano do } \\
\text { ensino } \\
\text { médio } \\
\end{array}$ & $\begin{array}{c}10 \text { ano } \\
\text { faculdade }\end{array}$ & $\begin{array}{l}1 \text { ㅇ ano do } \\
\text { ensino } \\
\text { médio }\end{array}$ \\
\hline $\begin{array}{c}\text { Atividade } \\
\text { Laboral }\end{array}$ & Não & Não & Não & Não & Não & Sim & Não & Não & Não & Sim \\
\hline Diagnóstico & $\begin{array}{c}\text { Leucemia } \\
\text { Mieloide } \\
\text { Aguda - } \\
\text { M3 } \\
\end{array}$ & $\begin{array}{l}\text { Germinoma } \\
\text { de Pineal }\end{array}$ & $\begin{array}{l}\text { Osteossarcoma } \\
\text { de joelho }\end{array}$ & $\begin{array}{l}\text { Leucemia } \\
\text { Linfoide } \\
\text { Aguda - AR }\end{array}$ & $\begin{array}{c}\text { Leucemia } \\
\text { Mieloide } \\
\text { Aguda - M2 }\end{array}$ & $\begin{array}{l}\text { Linfoma não } \\
\text { Hodgkin }\end{array}$ & $\begin{array}{l}\text { Sarcoma } \\
\text { de Ewing }\end{array}$ & $\begin{array}{l}\text { Linfoma de } \\
\text { Hodgkin }\end{array}$ & $\begin{array}{l}\text { Linfoma de } \\
\text { Hodgkin }\end{array}$ & $\begin{array}{l}\text { Linfoma de } \\
\text { Hodgkin }\end{array}$ \\
\hline $\begin{array}{c}\text { Data } \\
\text { Diagnóstico }\end{array}$ & 03/2008 & 03/2008 & $12 / 2007$ & $02 / 2008$ & $08 / 2006$ & $\begin{array}{c}\text { 06/2006 e } \\
\text { Recidiva em } \\
02 / 2008\end{array}$ & $04 / 2008$ & $07 / 2008$ & 09/2008 & $\begin{array}{c}\text { 03/2001 e } \\
\text { Recidiva } \\
\text { em } \\
08 / 2008 \\
\end{array}$ \\
\hline Tratamento & QT & $\begin{array}{c}\text { Cirurgia, QT } \\
\text { e RT }\end{array}$ & QT e cirurgia & QT & QT & $\begin{array}{c}\text { QT e } \\
\text { esplenectomia } \\
\end{array}$ & $\begin{array}{c}\text { QT e } \\
\text { cirurgia }\end{array}$ & QT & QT & QT e RT \\
\hline $\begin{array}{c}\text { Início } \\
\text { Tratamento } \\
\text { QT }\end{array}$ & 03/2008 & 03/2008 & $12 / 2007$ & $02 / 2008$ & 08/2006 & $07 / 2006$ & 05/2008 & 09/2008 & $10 / 2008$ & 03/2001 \\
\hline Ciclos QT & 3 ciclos & 4 ciclos & 12 ciclos & 8 ciclos & $\begin{array}{c}3 \text { ciclos }+4 \\
\text { (Manutenção) }\end{array}$ & $\begin{array}{c}7 \text { ciclos }+7 \\
\text { (Recidiva) }\end{array}$ & 5 ciclos & 4 ciclos & 2 ciclos & $\begin{array}{c}6 \text { ciclos }+ \\
6 \\
\text { (Recidiva) }\end{array}$ \\
\hline Religião & Católica & Adventista & Evangélica & Católica & Católica & Católica & Evangélica & Católica & Católica & Não tem \\
\hline $\begin{array}{l}\text { Data da } \\
\text { Entrevista }\end{array}$ & $07 / 2008$ & $\begin{array}{c}07 / 2008 \mathrm{e} \\
11 / 2008 \\
\end{array}$ & $\begin{array}{c}07 / 2008 \text { e } \\
11 / 2008 \\
\end{array}$ & $\begin{array}{c}08 / 2008 \mathrm{e} \\
11 / 2008 \\
\end{array}$ & $08 / 2008$ & $09 / 2008$ & $09 / 2008$ & $11 / 2008$ & $11 / 2008$ & $11 / 2008$ \\
\hline
\end{tabular}

Quadro 5 - Caracterização das crianças e adolescentes, segundo o nome, idade, escolaridade, atividade laboral, diagnóstico, tempo de diagnóstico, tratamento, início do tratamento quimioterápico, número de ciclos quimioterápicos, religião e data da entrevista. Ribeirão Preto, 2008. 
Apresentamos, de forma mais descritiva, outras características das crianças e adolescentes participantes do estudo:

A.

A., adolescente de 16 anos, reside com os pais e um irmão mais novo. A mãe é cabeleireira, mas deixou as atividades laborais para dedicar-se ao tratamento e acompanhamento do filho. Quando possível, faz alguns "souvenirs" artesanais como ímãs de geladeiras e brincos para ajudar na renda familiar que ficou a cargo do pai, motorista. Sempre que possível, a depender das folgas, o pai também acompanha o filho nos retornos ambulatoriais e hospitalares.

Notadamente, a religião é um ponto forte em toda a família de A. Católicos, vão sempre à igreja e encontram, na religião, a base para o fortalecimento da família, como observado durante a interação com a mãe:

"Mãe refere que é católica e que, junto com o marido, sempre vão com os filhos à igreja. Agradece pelas vitórias alcançadas e vê em Deus a fonte da força que tem para vencer as barreiras que surgem em seu dia a dia. Da mesma forma, estimula o filho a crer na ajuda de Deus e a agarrar-se à força que este proporciona." (Observação - Mãe de A.)

A família é muito unida. Observa-se que durante a interação com 0 adolescente e sua mãe há sempre menção dos outros membros da família (o pai e o irmão), mostrando laços de cumplicidade e amizade não surgidos agora, no momento do enfrentamento da doença, mas laços existentes desde a união dos pais que se estenderam e se fortaleceram junto a toda a família.

O início do tratamento foi muito difícil para a família. A. apresentou episódios de neutropenia febril e foram necessários longos períodos de internação, o que alterou o humor e o comportamento do adolescente, sendo este mais um momento difícil, principalmente para a mãe, cuidadora mais próxima, que precisou aprender a lidar com mais esta situação. Diante do processo vivenciado, A. fechou-se em serviços como o de psicologia. A mãe foi, tal como observado, a facilitadora em todos os momentos.

No decorrer do tratamento, as dificuldades passaram a acontecer apenas nos períodos de quimioterapia, que o deixava indisposto e com pequeno mal-estar. 
A mãe mostrou-se extremamente presente em cada etapa do tratamento, atenta às intervenções e procedimentos. Colaborou, orientou e estimulou outras mães que vivenciavam quadros semelhantes ao do filho. Apesar da mudança referida por eles em seu cotidiano, mostraram-se contentes e agradecidos, principalmente a Deus, pela vitória alcançada até o momento.

"Observando o adolescente e sua mãe durante os períodos de infusão, nota-se a presença da mãe em toda intervenção. Cada droga a ser infundida e procedimento a ser realizado vem seguido de uma pergunta da mãe sobre o que é, tempo de infusão, dor, intensidade da ação, possíveis reações e outras questões pertinentes à ação realizada pela equipe no momento. A mãe ainda relata os difíceis dias que vivenciaram para as outras mães da enfermaria e a vitória que hoje deslumbram com o bom estado geral de A., fortalece a esperança das outras pessoas." (Observação - Mãe de A.)

A mãe estimulou o adolescente em suas ações e enfrentamentos, assim como o preservou de qualquer possível dano, tal como relatado em relação aos cuidados de preparação dos alimentos e de limpeza do ambiente domiciliar. $O$ isolamento de pessoas externas ao ambiente domiciliar foi fortemente estimulado, a fim de garantir toda a proteção que estava ao seu alcance, liberando-o a visitas selecionadas apenas durante os momentos de completo bem-estar geral.

Vínculo e comunicação foram reforçados com atividades lúdicas (jogos) que aproximaram bastante o adolescente do pesquisador. O contato proporcionou ao adolescente expressar o momento vivenciado, focando-se, comumente, nas questões que envolviam o seu tratamento, mais do que a doença de base.

A entrevista com A. foi realizada, na maioria do tempo, apenas com 0 adolescente, sem a presença da mãe. $O$ mesmo estava no ambulatório de Oncologia Pediátrica aguardando por consulta para continuidade do tratamento. Mostrou-se bastante comunicativo, com bom estado geral e com grandes perspectivas para 0 futuro do tratamento.

"A. demonstra felicidade ao iniciar a quimioterapia por via oral. Apesar de relatar efeitos colaterais, são percebidos como mais amenos se comparados à via endovenosa. Refere que o desejo de voltar a sair com os amigos e ter seus animais de estimação presentes no seu dia a dia não está longe de ser alcançado, pois se sente melhor e observa sua melhora gradual, exemplificada por poder realizar a quimioterapia ambulatorialmente e em casa." (Observação - A.) 
A. foi, nos momentos que tivemos contato, um adolescente educado e receptivo a tudo que propusemos. Um grande facilitador foi a sua mãe que estimulou os contatos e propostas de atividades para a distração do filho. $O$ único momento de indisposição observado com A. foi durante a infusão dos quimioterápicos, visto as náuseas que apresentou.

B.

B., adolescente de 13 anos, mora com os pais e o irmão. Diante da necessidade de cuidados com o filho, a mãe de B. deixou suas atividades laborais para se dedicar exclusivamente a ele, sendo assim, a responsável pelo seu acompanhamento.

Passaram por período de estresse até a descoberta do diagnóstico, visto a incompatibilidade entre diferentes profissionais para a conclusão do mesmo e as fortes dores tipo cefaleia que incapacitavam o adolescente. Internado para realização de ressecção do tumor, $B$. ficou longo período (superior a um mês) em recuperação na enfermaria, apresentando dificuldade motora generalizada e afasia, somadas a crises convulsivas, o que gerou dúvidas quanto a um bom prognóstico.

Mostra-se infantil e dependente da presença da mãe, principalmente, durante os procedimentos invasivos, tal como observado durante a realização da quimioterapia. B. tem medo das punções venosas para infusão dos quimioterápicos, o que gera reações como sudorese, taquicardia e tremor.

"B. fica assustado antes de iniciar a punção venosa para administração do quimioterápico. Apesar de mencionar que sabe que a dor não é muito intensa, solicita a presença da mãe próxima a seu corpo e pede à enfermeira cuidado para a punção. Menciona, nervoso, estar suando e sentindo o coração bater mais rápido. Com o término da punção, vai referindo melhora da sudorese e taquicardia, além de conseguir se expressar melhor, mais tranquilamente." (Observação - B.)

B. teve boa recuperação das limitações que apresentou no início de sua internação, tal como observado em relatos durante as reuniões semanais da equipe. No momento, faz fisioterapia e mostra melhora gradativa da comunicação e movimentação. Fala com pequena dificuldade, observado pela pronúncia das palavras não tão claras, mas consegue expressar o que deseja. 
O contentamento pelas vitórias alcançadas é percebido pela expressão de B. que faz questão de relatar a sua história com detalhes. Reflete a satisfação de ter superado os problemas e dificuldades vivenciadas. Frisa o contraste entre o antes de iniciar o tratamento, com fortes dores e o momento pós-cirurgia e início da quimioterapia que the proporcionaram significativa melhora física e mudança em seu modo de ser, deixando-o menos tímido, mais comunicativo, ativo e pronunciando, inclusive verbalmente, ainda que de forma brincalhona, desejos próprios da puberdade alcançados com a adolescência, relatos que foram confirmados e reforçados pela mãe.

"B. conta várias vezes os momentos de dor de cabeça que teve antes da cirurgia, dores intensas e incapacitantes, pois o deixavam zonzo, sem reação. Com a cirurgia realizada em Ribeirão Preto, após semanas de internação, B. foi se reabilitando e hoje menciona que não tem mais nada, que está curado. Com toda esta vivência, diz que não tem mais vergonha dos familiares, anda de toalha pela casa e se troca no quarto, após o banho, diferente de tempos anteriores que já saía pronto do banheiro. $B$. menciona ainda que não se sente tímido como antes, mas mais extrovertido. De forma repetitiva também comenta o desejo de sair para namorar e passear na praça da cidade." (Observação - B.)

Notadamente, B. menciona por diversas vezes uma moça que trabalha perto da sua casa. Apesar de ela ser mais velha, adulta, ele destaca a atenção dela para com ele, uma amizade que o faz se sentir bem e estimula o seu desejo de recuperação. Observamos, ainda, um desejo dele com relação a um possível namoro, porém, por mais infantis que ainda sejam suas atitudes, é interessante ver como ele se refere continuamente a ela, sempre relacionando sua recuperação com o próximo momento de vê-la.

Apresentou, nos encontros, necessidade de se comunicar e ser ouvido, o que foi prontamente estimulado. As entrevistas ocorreram no ambulatório, enquanto aguardava a consulta e em quarto individual da Central de Quimioterapia, previamente à infusão dos quimioterápicos, com a presença da mãe.

C.

C., menina de 11 anos, mora com os pais e tem dois irmãos mais novos, sendo um, uma irmã de poucos meses. Os pais de C., para acompanharem seu 
tratamento, dividiam-se durante os retornos, mas após o nascimento de sua irmã, a mãe passou a acompanhá-la sempre, deixando os outros filhos com os avós. Com a doença, a mãe de C., empregada doméstica, deixou o trabalho e coube apenas ao pai o sustento da família.

C. refere, como sua maior dificuldade, a tristeza decorrente do isolamento dos familiares. Quando internada para a quimioterapia, chora pela distância dos irmãos e do pai e valoriza as idas para a casa da avó e as brincadeiras com os irmãos.

A mãe de C. a deixa bastante à vontade no ambiente hospitalar, mas mostrase presente. Menciona que a própria filha a encorajou a aguentar o sofrimento.

"A mãe de C. menciona que não teria suportado vivenciar esta experiência sem a ajuda da própria filha, pois a mesma a encorajou em todo o processo mostrando nitidamente o quão importante é a esperança de vencer a doença." (Observação - Mãe de C.)

Observamos a necessidade da criança quanto à presença da mãe, principalmente nos procedimentos. Expressa medo quando percebe a necessidade de intervenções, como punções venosas do cateter para administração de quimioterápico, tanto pelo procedimento doloroso quanto por já esperar mudanças no seu estado geral devido aos efeitos colaterais das drogas.

"C. tem medo das punções venosas, tanto periféricas quanto no cateter. Chora e pede pra mãe lhe dar a mão. Após a punção apresenta-se mais calma, mas a tensão continua. Seu humor e modo de agir são alterados, ficando menos responsiva ao contato e sem vontade de realizar atividades lúdicas, muito aceitas em outros momentos." (Observação - C.)

Quando em bom estado geral, C. retorna à escola e demonstra felicidade pelo retorno. Em casa, quando liberada pela mãe, recebe visitas principalmente de amigas e aproveita para brincar de escola, o que lhe faz muita falta.

"C. menciona gostar de ir à escola e sente falta pela interrupção, no entanto, fica feliz por hoje a volta à rotina escolar estar mais próxima. Quando não vai à escola, brinca com o irmão e as amigas que recebe em casa, como se estivesse na escola, sendo a professora." (Observação - C.)

O andador, presente no seu cotidiano desde a cirurgia no joelho, é ainda visto com descontentamento e agora, com a melhora do quadro, sempre que consegue, 
dá alguns passos sem o andador, tentando "fugir" da observação da mãe que, contrariamente, deixa o andador ao lado de sua cama e estimula o seu uso em todos os movimentos.

As entrevistas com $C$. se desenvolveram de modo tranquilo, realizadas sem a presença da mãe. Ocorreram no ambulatório, enquanto aguardava a consulta de retorno. Estes foram momentos descontraídos.

Vale dizer que as diversas brincadeiras realizadas durante os encontros estimularam consideravelmente a comunicação verbal da menina e facilitaram o vínculo estabelecido. Durante todos os contatos, foi marcante o grau de orientação de C. quanto à sua trajetória e a certeza da vitória em futuro próximo, graças a Deus.

"A fim de entender a doença e o tratamento que realiza, C. leu um livro que ganhou do psicólogo sobre o assunto e, a partir dele orienta a própria família, como mencionou. Demonstra saber o perigo da sua doença ao comentar sobre a malignidade do tumor e a força deste, mas se agarra à vitória conquistada por não ter se submetido à amputação, como prevista inicialmente e ao fato de só presenciar o que tem forças para vencer." (Observação - C.)

D.

D., oito anos, mora com os avós, as irmãs (mais velhas) e a mãe. O pai, etilista, não colabora com os custos da família e não acompanha a criança, o que faz com que a mesma veja no avô, participativo em seu dia a dia, a posição de pai. A mãe trabalhava como doméstica, mas precisou deixar o emprego para acompanhar e cuidar da filha.

Diante das restrições impostas pela quimioterapia, a mãe refere que D. é bastante responsável e sempre usa a máscara, pergunta se pode comer algo em específico e ajuda a mãe. D. mostra conhecimento quanto à limpeza de verduras e ensina como deve ser todo o processo.

D. destaca, entre as principais limitações, a restrição em brincar com os amigos. Antes da doença, brincava na rua do bairro onde mora com diversas crianças. Hoje, no entanto, se revolta ao ter de pedir à mãe para sair para brincar, o que nem sempre é concedido. Ainda diante das limitações, aponta a falta de atividades físicas na escola e o fato de não ter mais ido à igreja. 
"Antes da doença, D. relata que saía de casa todas as noites para brincar nas ruas do seu bairro com outras crianças. No entanto, identifica a doença e a quimioterapia como responsáveis pelas restrições, por não poder mais sair de casa, ir à escola e brincar como antes. Fala ainda, insatisfeita, da força de sua mãe em restringi-la em casa." (Observação - D.)

A doença trouxe mudanças no modo de ser de D., pois antes da doença, segundo a mãe, D. era uma "manteiga derretida", chorava constantemente. Com a doença, D mudou seu comportamento e combinou com a mãe só chorar por dor!

"A mãe de D. menciona a sua diferença comparada ao período anterior à doença. Comenta que antes a menina chorava por qualquer coisa e se tivesse se mantido assim, a deixaria em pânico em todo o tempo, por não conseguir entender a gravidade de cada situação, o que a fez combinar com D. que esta só choraria se tivesse algo realmente sério." (Observação Mãe de D.)

Os primeiros contatos foram marcados pela timidez de $\mathrm{D}$. que deixou lugar para uma criança ativa, alegre, cheia de energia durante os jogos realizados como estratégia para o estabelecimento de vínculos.

Vale ressaltar o contraste de sua reação durante a internação e realização de quimioterapia e quando em consulta ambulatorial. Foi mais receptiva durante o retorno ambulatorial, o que facilitou o contato e a entrevista. Quando realizava quimioterapia, observaram-se mal-estar e vômitos frequentes.

"Apresenta-se alegre e falante durante as brincadeiras, principalmente em retornos ambulatoriais, contrariamente aos momentos de internação e, principalmente de infusão de quimioterápicos." (Observação - D.)

As entrevistas foram realizadas no ambulatório e ainda na enfermaria, com a presença da mãe, facilitadora no processo de recuperação e de formação de vínculo.

E.

E., 15 anos, mostrou-se reservado durante os contatos e não se interessou por atividades lúdicas, diferentemente de outros participantes do estudo.

E. mora com a mãe e um irmão mais novo. Tem ainda um irmão mais velho que mora com o pai. Apesar de viverem em casas separadas, o pai é presente no seu 
dia a dia e é responsável pelo custeio financeiro da família, sendo responsabilidade da mãe seu acompanhamento durante todo o processo.

O irmão mais velho de E. teve LLA com 1 ano de idade, mas E. não vivenciou, pois no início do tratamento, sua mãe ainda estava grávida dele. Após o nascimento, quando ainda pequeno, o irmão encerrou o tratamento. Hoje o irmão, segundo a mãe, está bem, recebeu alta e realiza suas atividades normalmente.

E. está em fase de manutenção e refere estar se sentindo bem com o tratamento. Descobriu o câncer há dois anos e, desta forma, talvez pelo tempo já decorrido e pela fase do tratamento em que se encontra, sua reação não esteja mais ligada a tantas preocupações e incertezas, porém mantém a insatisfação diante das restrições impostas pelo tratamento, principalmente por necessitar ficar em casa.

"E. refere que sente os efeitos colaterais do tratamento somente nos primeiros dias da infusão e, passado este período, se sente melhor. No entanto, destaca o desejo por sair com os amigos, ir à escola e não ter sua imagem corporal alterada com a queda de cabelo, o que the incomoda." (Observação - E.)

Relatou sua experiência mostrando conhecimento da situação. A entrevista ocorreu na Central de Quimioterapia, em local reservado, com a presença da mãe. Nesse momento, influências de experiências relacionadas ao tratamento do irmão não foram referidas.

F.

F., 17 anos, mora com a madrinha - irmã paterna - desde os quatro anos de idade, quando sua mãe faleceu (mãe era etilista e teve acidente vascular cerebral com 38 anos). O pai, já idoso e com cardiopatias, faleceu em 2007. Filho do segundo casamento do pai, tem outros irmãos, porém, sem contato.

Diagnosticado com câncer em 2006, foi tratado e atualmente vivencia uma recidiva. Calmo, não mostra reações de ansiedade, pelo contrário, em todos os encontros mostrou-se tranquilo e esperançoso, sem revoltas ou mudanças de humor. Refere não ficar se perguntando os porquês, simplesmente vive o dia a dia. Observamos sentimento de esperança de um bom resultado com o transplante de medula, alternativa de tratamento que vem sendo proposta. Não tem nenhum irmão 
compatível, mas ainda assim aguarda o surgimento de um doador e do momento em que poderá se submeter a este tratamento.

"F. menciona aceitar o tratamento oferecido até então e vê, na vitória alcançada durante a primeira manifestação do câncer, um bom resultado para o futuro do tratamento que hoje realiza, apostando no transplante de medula, sua esperança." (Observação - F.)

F., durante entrevista na enfermaria, com a presença da madrinha, menciona que quer voltar a trabalhar na oficina mecânica com seu padrinho, este é, no momento, um dos seus maiores desejos, afinal, esta seria sua atitude diante da confirmação de um resultado satisfatório quanto ao seu tratamento.

"Voltar a trabalhar com o padrinho é o desejo atual de F. Trabalhando e estudando ele se sentia útil e ainda ajudava os padrinhos que o criaram desde criança." (Observação - F.)

G.

G., 15 anos, é a caçula de dois irmãos. Mora com a mãe, mas durante o período de tratamento, está ficando hospedada temporariamente na casa da irmã, do irmão e outros familiares, tendo, desta forma, vários membros diretamente ligados ao seu cuidado.

Buscou ajuda médica para um diagnóstico benigno e acabou descobrindo um câncer, o que lhe trouxe reações de revolta. Adolescente, viu-se em um meio inimaginável até então e teve dificuldades em lidar com a situação e a absorção do impacto da doença, gerando atitudes de distância do que estava vivenciando e, ao mesmo tempo, raiva e questionamentos, além de fortes preocupações com a autoimagem.

"G. conta com detalhes o processo de busca pelo seu diagnóstico, desde procurar o serviço de atenção básica do seu município até o encaminhamento para o HCFMRP - USP. Com diagnóstico inicial de osteomielite, iniciou o tratamento, no entanto, sem melhora, descobriu associado o diagnóstico de câncer. No início, mesmo sem a real ideia da gravidade do câncer, não mencionava nada sobre o assunto e não participava, rejeitando a situação que era imposta de forma, por vezes, grosseira e com raiva, fatos confirmados pela equipe de psicologia, a qual não era aceita inicialmente. A preocupação, de início, foi com a autoimagem, observada pela necessidade de estratégias para esconder a alopecia, além da preocupação com a perda de peso." (Observação - G.) 
A subnutrição que se instalou, o tamanho e as características do tumor, a cirurgia necessária e uma previsão de ciclos quimioterápicos difíceis não indicavam um bom prognóstico.

Com o decorrer do tratamento, G. mostrou-se rebelde, inclusive agressiva verbalmente com os familiares. Os membros da família sofreram calados por imaginar uma provável amputação do membro inferior de G. que não veio a se confirmar.

"A irmã mencionou preocupação diante do quadro e da gravidade da doença de G. e, junto com a família, tentaram deixar o ambiente hospitalar o mais próximo possível do domiciliar, trazendo alimentos de casa, quando liberados e um notebook com internet para o acesso no hospital sem, no entanto, mencionarem os maus-tratos verbais pronunciados, no início do tratamento, pela adolescente." (Observação - Irmã de G.)

Com uma resposta satisfatória aos quimioterápicos e uma cirurgia sem amputação do membro, G. começou a perceber melhora do quadro e tornou-se mais receptiva à equipe e menos reativa aos familiares.

A família, de forma geral, conforme os relatos, passou a frequentar mais a igreja e se apegar à religião.

A entrevista ocorreu na enfermaria, com a presença da mãe, em uma fase de maior aceitação de G., diante de todo o processo e quando a mesma já se recuperava da cirurgia. O vínculo estabelecido ocorreu sem a utilização de estratégias lúdicas, pois, diferentemente dos outros adolescentes, G. foi presenteada, pela família, com um notebook e uma conexão portátil de internet, o que foi responsável pela sua distração durante a internação.

$\mathrm{H}$.

H., 16 anos, mora com a mãe e o irmão mais velho. Com pai ausente, a mãe é a única cuidadora de H. e, para acompanhar o seu tratamento, precisou parar de trabalhar. Vendo a família viver com poucos recursos financeiros, o irmão mais velho passou a colaborar.

Ao conversar com $\mathrm{H}$. e sua mãe, os dois mostraram-se receptivos e, para a mãe, foi evidente este momento como uma oportunidade de desabafo de suas dificuldades e também de alegria diante de ter a família ainda mais unida, fato confirmado pela equipe da Central de Quimioterapia. 
"A mãe demonstrou necessidade de relatar a trajetória do filho e a mudança que todo o processo gerou na rotina familiar, principalmente pela maior limitação financeira decorrente de sua interrupção laboral para o cuidado de $H$. Apesar das dificuldades vivenciadas, a mãe faz questão de não permitir o distanciamento dos três membros da família, reforçando o vínculo entre eles e mencionando o orgulho que tem dos filhos, o que é destacado em todo o seu depoimento." (Observação - Mãe de H.)

H. também aproveitou para desabafar, no entanto, o grande destaque foi, como observado pelos contatos, a mudança interior a que $\mathrm{H}$. se propôs com ele mesmo. Antes da doença, $H$. pensava muito em questões materiais, em objetos de marca, em aparências. Depois, sua visão de mundo mudou e H. passou a enxergar a importância de outras coisas, outros valores e principalmente valorizar mais a sua família.

"H. mencionou ter agregado valores de vida diferentes dos que tinha antes da doença. Passou a enxergar o seu dia a dia de outra maneira, não se importando com ter ou não um determinado produto de marca reconhecida, mas ter uma família que o apoia e o ajuda em todos os momentos. Atividades como assistir a filmes em casa passaram a ser prazerosas." (Observação - H.)

H. se apresenta como um rapaz responsável e preocupado com o futuro, com sua formação e ansioso para terminar o tratamento e começar a trabalhar para ajudar a família. A mãe e o irmão são a base de $\mathrm{H}$. e o estímulo para a continuidade do seu tratamento.

A mãe o acompanhou na entrevista, ocorrida na Central de Quimioterapia, em local reservado. H. preferiu conversar sem a mediação das atividades lúdicas. Mostrouse respeitoso com as orientações da mãe e mencionou sentir-se como um vencedor diante das vitórias já alcançadas, mais disposto com o término do tratamento.

I.

I., 17 anos, mora com os pais e a irmã mais nova, de 14 anos. Calma, conta o que tem vivenciado desde a procura do diagnóstico. Em 2008, ano de início da doença, havia começado a graduação em farmácia, na faculdade de sua cidade. Devido à intensa icterícia que apresentou, procurou o serviço médico e acabou tendo o diagnóstico de linfoma, levando-a a trancar sua matrícula no curso.

I. já teve uma experiência com o câncer no passado, pois a sua mãe se submeteu a tratamento quimioterápico para câncer de mama. Esta, no entanto, não foi uma boa experiência, visto que a mãe apresentou intensos efeitos colaterais, o que 
a levou a ter expectativas da mesma natureza com o seu tratamento, gerando temor antes do início do mesmo.

"Por ter presenciado o tratamento quimioterápico, assim como as manifestações de mal-estar apresentadas pela mãe, l. esperava sintomas do mesmo gênero diante do seu tratamento, o que a fez sentir medo e tristeza também pela perda de cabelo que aconteceria, visto o grande apreço e vaidade que tinha com seu cabelo." (Observação - Mãe de I.)

Para seu espanto, felizmente, ao menos nos primeiros ciclos, I. observou poucas reações adversas, mais amenas do que as vivenciadas pela mãe. Aliviada, assim como toda a família, I. mostrou força e esperança para alcançar um bom resultado diante do quadro. A mãe, recuperada, temia o sofrimento da filha, mas a acompanha em todo o processo, dando força, estímulo e apoio a todo instante.

Por ser residente em outro estado, I. deixou a faculdade e os amigos, mudando sua rotina. Atualmente, ela e a mãe residem com familiares em domicílio próximo do HCFMRP - USP. O pai e a irmã continuam residindo na cidade de origem, mas sempre vêm visitá-las.

A entrevista, realizada na Central de Quimioterapia com a presença da mãe, apontou destaque para a relação com a imagem corporal, enfatizando uma grande mudança, visto que apresentava cabelo comprido, mas mesmo antes do tratamento cortou-o. Relatou queda intensa e frequente (dois ciclos de QT) e a preocupação com a ausência do cabelo, mas acima de tudo, a esperança de um bom resultado.

J.

J., 18 anos, mora com a mãe, o irmão mais novo (13 anos), a avó e o avô. Tem ainda uma irmã casada (21 anos). Com relação ao pai, mencionava não vê-lo desde os seis anos de idade.

J. convive com o câncer desde os 11 anos, quando teve a sua primeira manifestação. Nessa época, conviveu com longos períodos de internação, principalmente no início do diagnóstico. Em 2001, teve alta do tratamento quimioterápico e da radioterapia. Durante todo esse período, compareceu aos retornos anuais do hospital e conseguiu, conforme relato, ter uma vida sem as implicações que o tratamento ocasiona. Em 2008, no entanto, apresentou um abaulamento cervical que o fez procurar o serviço novamente, sendo diagnosticada recidiva do linfoma. 
O momento, no entanto, segundo J. é muito diferente, assim como todo o processo. J. menciona que, na primeira vez, ele não tinha noção da gravidade e nem planos para a sua vida, o que foi menos doloroso. Hoje, quando descobriu a doença, apesar de ter como visão um resultado ainda positivo do tratamento, J. já vislumbrou o sofrimento que o espera durante o processo de doença e tratamento.

"Ser criança e não entender a gravidade é tido, por J., como um facilitador para o enfrentamento da doença, diferente de conhecer o sofrimento decorrente do tratamento. No entanto, acredita no tratamento e no seu sucesso se realmente se dedicar a realizar o que for proposto para o combate da doença." (Observação - J.)

J. também vive um momento muito particular em sua vida. Acabara de descobrir que ia ser pai. Tinha grandes planos para o trabalho, visto que a partir de então precisaria sustentar sua família.

"Feliz e ao mesmo tempo preocupado com a situação de doença que enfrentava diante da impossibilidade de trabalhar para o sustento da nova família que se formaria." (Observação - J.)

Com poucos meses de gestação, sua namorada perdeu a criança, o que, apesar de triste para a família que já havia aceitado a situação, tem ainda o fato de J. ter que conviver com este momento de dupla perda, do filho e da vida livre da doença.

Amparado pela sua família e pela de sua namorada, J. continua morando com a mãe e se dedicando exclusivamente ao seu tratamento. Comparece ao serviço de quimioterapia sozinho ou acompanhado de um primo, conforme a disponibilidade do último.

J., entrevistado na Central de Quimioterapia, não se queixa da situação, pelo contrário, agradece pela força que está tendo e luta para acabar logo esta nova etapa, voltar a estudar e então trabalhar para se realizar profissionalmente.

"Apesar da interrupção temporária dos planos que trilhou, menciona o desejo de terminar o tratamento, reiniciar sua atividade laboral e então pensar na nova família com sua namorada." (Observação - J.)

Apresentamos, a seguir, os temas ao redor dos quais foi organizado o material empírico, basicamente das entrevistas. 


\subsection{A DOENÇA}

\subsubsection{Trajetória até o diagnóstico}

A definição do diagnóstico nem sempre acorre imediatamente, mas após os primeiros sinais e sintomas manifestados pela criança ou adolescente e observados pelos seus familiares. No entanto, estes descrevem tais sinais e a trajetória nos serviços de saúde, mesmo passado o tempo, com grande riqueza de detalhes, incluindo as preocupações, dúvidas e procedimentos envolvidos na busca pela resolução dos problemas de saúde. A criança, ao perceber o familiar se voltando integralmente para ela na procura pelo diagnóstico, expõe sentimentos de preocupação com relação à falta de conforto dos cuidadores ao acompanhá-la no hospital.

"Eu comecei a sentir que eu estava muito fraco, meio com gripe, só que não espirrava, não escorria nada. Daí uma noite eu acordei meio enjoado e pálido, fiquei meio anêmico. Aí minha mãe me levou no posto, tiraram sangue e eu voltei pra casa. Nisso eu comecei vomitar. No outro dia eu voltei pro posto, aí ela [médica] falou: 'Deu uma anemia e a gente tem que tratar isso, vamos tirar outro sangue, volta pra sua casa.' Isso foi de manhã. Eu voltei pra casa, aí quando minha mãe terminou de fazer o almoço, a hora que eu fui pra comer, chegou uma mulher lá em casa e falou que era pra eu voltar pro posto que descobriram outra coisa, que eu tinha que voltar urgente. Eu voltei pro posto e ela [médica] já me mandou direto pra cá $[\mathrm{HC}]$. A hora que eu cheguei aqui eu fiquei uma meia hora na sala de espera, nisso já me chamaram pra entrar pro isolamento, eu não sabia o que eu tinha." (A. 16 anos)

"Eu sentia dor de cabeça, dor no corpo e fiquei amarela. Se eu fizesse assim pra ver como que estava o sangue [aperta a ponta do dedo], só vinha dessa cor, só ficava amarelo. Aí minha mãe e minha avó me levaram ao médico [da cidade de origem] e ele falou: 'Vamos encaminhar ela direto pra Ribeirão pra gente fazer um exame.' Fez o exame, mandou pelo computador. Na quinta-feira, eu já fui lá [UE]. Aí ele falou: 'A gente vai ter que internar ela urgente porque está saindo sangue do corpo dela e a gente não sabe por onde.' Internou lá no $H C$ velho [UE]. Eu falei: Mãe eu não quero internar, eu quero ir embora, e comecei a chorar. Ela falou: 'Você precisa ver o que é isso filha, então vamos ficar aqui.' Minha mãe teve que dormir debruçada na cama, ela não conseguia dormir, ela acordava toda hora." (D. 8 anos) 
Em pesquisa realizada com pais de crianças e adolescentes em hospital de referência para o tratamento oncológico, objetivando descrever a trajetória percorrida desde $\circ$ aparecimento dos sinais e sintomas até a confirmação diagnóstica, evidenciou-se que este período foi de grande significância para os pais, visto que, assim como observamos com as crianças, os pais, nesse estudo, relatam com exatidão os tempos cronológicos envolvidos no processo e os desafios (CAVICCHIOLI; MENOSSI; LIMA, 2007).

Participantes deste estudo mencionam a procura, às vezes necessária, por diversos profissionais, inclusive de serviços particulares, devido à demora ou não resolutividade nos serviços públicos até a confirmação do diagnóstico.

"Minha mãe descobriu no comecinho. Eu cheguei da escola e meu joelho só estava inchado. Tinha uma bola de lado. Minha mãe me levou no médico e o médico falou: 'É água no joelho. Segunda-feira vocês vêm pra tirar água do joelho.' Minha mãe não deixou, aí eu fui ao posto de saúde, passei com o doutor que disse que era um reumatismo. Ele passou um comprimido pra tomar e eu tomei. Aí minha mãe pagou uma consulta particular, tirou um raio $\mathrm{X} \mathrm{e}$ descobriu que era um tumor maligno. O médico particular me encaminhou pra cá $[H C]$. No dia 04 de dezembro eu vim pra Ribeirão, mas eu tinha descoberto lá na minha cidade no dia 28 de novembro." (C. 11 anos)

Cavicchioli, Menossi e Lima (2007) apontam, referindo-se à trajetória percorrida até o diagnóstico de câncer, diversas hipóteses diagnósticas e dificuldades encontradas para a realização de exames diagnósticos e para os necessários encaminhamentos aos serviços especializados, refletindo o comprometimento de princípios do SUS como acessibilidade e integralidade.

Um dos participantes do estudo, ao relatar a vivência deste momento, com diferentes hipóteses sobre seu caso, menciona que adotou as opiniões que conferiram um caminho tido como menos doloroso, com um diagnóstico menos grave. A realização de procedimentos invasivos e desconhecidos e a definição de um diagnóstico não desejável para a criança causam grande impacto, o que pode ser demonstrado com a recusa ao diagnóstico proposto, com limitações e mesmo bloqueios da memória, nos períodos de maior estresse.

"Doía muito a cabeça. Eu acordava cedo com essa dor, não aguentava mais, tomava remédio, mas nem com remédio a dor passava. Eu levei os remédios na escola e tomei uma cartela de paracetamol. Não passava, eu 
tomava, ficava bêbado, não conseguia nem andar, minha mãe precisava me segurar. Colocaram duas válvulas, mas a dor de cabeça continuava. A válvula estava entupida, só que se ela não tivesse entupido, não tinha descoberto o tumor. O médico [da cidade de origem] falava que tinha água no cérebro. Eu não sabia o que era. Minha mãe foi mostrar pro médico a tomografia e ele mandou internar. O médico [cidade de origem] não viu o tumor na cabeça e o daqui viu. Aí nós saímos lá fora, eu sentei com o meu pai e falei: Esse médico é mentiroso pai, eu não tenho tumor na cabeça, ele está mentindo, é mentiroso. Vamos voltar com o médico de lá [cidade de origem]. Aí internou. Tirou água da cabeça com a seringa, eu cheguei a desmaiar. Tirou quatro seringas de água da cabeça e fizeram eu acordar. Aí já não lembro de mais nada. Eu só sei que eu saí de casa, já não lembro mais. Saí sem falar, sem andar, sem enxergar, sem nada. Eu não lembro, eu não pensei nada." (B. 13 anos)

A fase de espera de confirmação do diagnóstico do câncer é considerada um período de estresse e preocupação. Receber o diagnóstico de câncer é lembrado como uma experiência dramática em suas vidas (SAEGROV; HALDING, 2004).

Segundo Woodgate, Degner e Yanofsky (2003), em estudo no Canadá para explorar e descrever os sintomas do câncer na infância, na perspectiva de crianças e familiares, a dor é um sintoma presente no cotidiano das crianças e dos adolescentes com câncer, seja a dor decorrente dos procedimentos invasivos, do tratamento ou do próprio câncer, o que reforça o sofrimento natural da doença.

Observamos que, de início, a similaridade de sinais e sintomas do câncer infantil com outros quadros como os virais ou infecciosos termina por facilitar a demora do diagnóstico final que é, por vezes, permeado de diferentes hipóteses. Da mesma forma, a associação de outros diagnósticos com o câncer pode atrapalhar a descoberta do mesmo.

"Eu tratava como osteomielite. Fiz uma biópsia e uma raspagem. No começo, ele [tumor] estava pequeno, então não deu. A ressonância deu que era osteomielite. Aí conforme fizeram a raspagem, a célula se espalhou, foi onde ele cresceu mais e depois de dois meses mais ou menos, a dor voltou e eu fiz a segunda biópsia que deu que eu tinha um tumor maligno no fêmur, na coxa. A médica explicou pra minha mãe, mas eu não fiquei sabendo, fiquei sabendo estes dias o tamanho que estava." (G. 15 anos)

Woodgate e Degner (2004), em estudo para descrever, tal como experienciado por crianças e seus familiares os sintomas do câncer, mencionam que há uma transição de sintomas e que esta influencia o modo de ser das crianças e familiares. 
Os períodos de transição são encarados pelas famílias de diferentes formas. Neste sentido, os papéis e responsabilidades dos familiares também variam de acordo com o período em que se encontram. Para exemplificar, geralmente antes do diagnóstico da doença, vivenciam o período como uma fase normal e própria do crescimento, não associada, pela maioria, à ameaça do câncer. No entanto, com as mudanças ou intensificação dos sintomas, as alterações podem ser consideradas graves, e a doença passa a interferir mais na vida dos familiares e da criança. Há também fases em que os sintomas se apresentam mais específicos e relacionados ao câncer, provocando nas crianças e familiares o real sentimento de estar doente, o que reflete, neste período, um momento tido como normal e próprio da fase de doença em que se encontram.

Ao conhecer o diagnóstico, uma das crianças relata que este tem um forte impacto nos seus familiares, afetando a saúde deles.

"Minha mãe estava grávida, ela começou a passar mal, foi pra Santa Casa ganhar neném e eu vim com o meu pai." (C. 11 anos)

Segundo Woodgate, Degner e Yanofsky (2003), o desgaste físico e mental, a exaustão que todo o processo causa nas crianças e nos familiares, o medo e a intranquilidade reforçam as incertezas da vida frente ao câncer, deixando-a mais dolorosa.

Muitas vezes, o processo de diagnóstico é abstraído das percepções do adolescente, seja pelas dificuldades de entendimento da situação vivenciada no momento, seja pelo impacto que causa, levando o adolescente a pouco se expressar e participar diante dos fatos vivenviados.

"Eu fiquei com trauma, fiquei internado. Eu não lembro, só lembro um dia que estava meu pai, minha mãe, meu irmão e a namorada dele, eu estava usando uma bota de ferro segurando o meu pé, meu pé estava entortando, uma bota de ferro pra ficar lá, firme. Fez uma bolha ali, tem a marca da bolha. Lembro de poucas coisas, lembro dessa bota de ferro." (B. 13 anos)

Há sinais e sintomas que podem estar associados às neoplasias e, quando conhecidos pelas crianças e adolescentes, como em situações de recidiva, são identificados, e imediatamente eles procuram ajuda médica. $O$ difícil momento de 
comunicação da elucidação do diagnóstico, portanto, pode não ser único na vida das crianças e adolescentes.

"Da primeira vez [teve câncer há sete anos] descobriu porque me deu pneumonia, aí internou. Deu pneumonia com água no pulmão, fiquei 30 dias internado. Não achavam o que era, tinha um buraco aqui pra água que não parava de criar, tinha até um dreno [drenagem de tórax]. Quando foi no meu aniversário, me transferiram pra Ribeirão pra fazer outros exames. Eles tinham feito uma biópsia do meu pescoço, uma glândula pra ver, descobrir alguma coisa, descobriram que era um linfoma e eu comecei a fazer quimioterapia. Da outra vez disseram que tinha uma íngua, mas eu não lembro. Desta vez, começou a inchar no meu pescoço, no local, eu achei estranho e procurei [o médico] na minha cidade e ele falou que talvez podia ser gânglio inflamado, mas eu já tinha um retorno em Ribeirão, então deixei pra perguntar pra médica mesmo. Aí o doutor fez o exame e viu que era o retorno do linfoma, mas agora, desta vez, foi mais visível." (J. 18 anos)

"Minha barriga inchou, meu fígado e meu baço incharam. Eu tive que tirar o baço porque ele não voltou ao tamanho normal. Eu terminei o tratamento em janeiro de 2007 e voltou agora em fevereiro [2008] de novo. Ficava dura a barriga, do lado. Eu fiz exame de sangue e o resultado dava tudo baixo, me transferiram pra cá $[\mathrm{HC}]$. Aqui eu fiz biópsia do fígado e descobriu, depois de um mês, que eu estava com câncer no fígado." (F. 17 anos)

O impacto de uma recidiva traz a angústia de passar novamente por todo o sofrimento, mas, de forma ambígua, mantém-se acesa a esperança, visto a superação que tiveram diante da primeira manifestação do câncer.

"Foi muito ruim descobrir essa doença, é chato. Eu tratei e depois voltou de novo. É ruim porque eu pensei que eu já estava curado, aí voltou de novo, é chato." (F. 17 anos)

"Eu falei: Eu sei que é difícil passar de novo por tudo o que eu passei, o tratamento, mas se eu superei a primeira, eu supero a segunda. É estranho ter de fazer tudo de novo o tratamento. Agora eu sei como vai ser, eu sei que tem cura, que não vai matar ninguém, mas é ruim, realmente é ruim. Tem que vir aqui direto, passa mal quando faz quimio, é esquisito mesmo. Só chorei porque eu vi minha mãe chorar. Hoje ela está bem, conformada, trabalha normalmente, mas se preocupa, eu acho." (J. 18 anos) 


\subsubsection{Conhecimento sobre a doença}

A definição dada pelas crianças ou adolescentes mostra-se bastante resumida, com conceitos distorcidos ou errôneos. Mencionam terem ouvido e/ou lido a respeito da doença, no entanto, muitas vezes não conseguem expressar sua compreensão a respeito das informações. Na definição, alguns se referem ao nome correto da doença, apontando a principal característica ou detalhes como o tamanho do tumor, além de sua localização.

"Eu sei que é uma doença do sangue. São células mortas que ficam na medula, acho que é isso, leucemia. A minha não tem um por que, aconteceu mesmo, não foi tipo genética, nada assim, foi porque aconteceu. Aquela célula morreu e foi matando outras." (A. 16 anos)

"Eu sei que o tumor que eu tinha é o osteossarcoma, tumor maligno. Ele [médico] falou que era maligno. Eu não sabia o quê que era o tumor ainda, depois que ele [médico] foi falar que o tumor é tipo uma massa que dá a dor, por pressão. O benigno não cresce, o maligno cresce. Ele falou que era o maligno, minha perna foi só crescendo." (C. 11 anos)

"É uma doença que tem vários glóbulos brancos. Os glóbulos brancos podem estar pra cima e o vermelho pode estar pra baixo ou ao contrário também." (D. 8 anos)

"É uma doença do sangue, só." (E. 15 anos)

"Eu sei que é uma doença maligna. Eu tenho câncer no fígado e na medula. Eu sei que é linfoma, mas o nome é difícil de falar. Falaram um monte de coisa pra mim. Não sei muito, abaixa a resistência." (F. 17 anos)

"A única coisa que eu sei é que é um câncer, que ele [médico] explicou pra mim que é linfoma, que inflamam os linfonodos e é mais ou menos isso. $E$ eu pesquisei na internet e falava que tem vários." (I. 17 anos)

Ao pesquisar sobre a doença, o adolescente procura comparar o que é apresentado na literatura com as alterações presentes em seu corpo e decorrentes da doença.

"Todos os sintomas que é da doença eu tive mesmo, coceira, suando de madrugada, caroços, gânglios, esses sintomas que eu tive. Achei legal, tudo o que eu tive mesmo é sobre a doença." (H. 16 anos) 
Os participantes, diante do diagnóstico e de seus preconceitos, veem o câncer como uma doença fatal que poderá levar à morte ou a sequelas permanentes, sofrendo com este possível desfecho.

"Aí o médico perguntou: 'Você não sabia que o seu filho tem um tumor na cabeça? Tem risco de morte." (B. 13 anos)

"Que eu ia morrer [pensou], porque ele [médico] chegou com uma cara assim e falou: 'É dos piores, não é dos fracos não.' Aí eu assustei." (C. 11 anos)

"Comecei chorar porque fiquei abatida, não sabia o que era isso, pensei que fosse alguma coisa que ia me matar. Minha mãe começou a chorar, em todo lugar que ela ia eu pegava ela chorando." (D. 8 anos)

"Que eu não ia viver mais, que a doença estava muito grave, pensei que estava acabando a minha vida, acabando ali. Mas aí eu comecei a perguntar pros médicos e eles começaram a me explicar melhor, que não era nada daquilo, que não era aquilo que eu pesquisei. Você tem que ver em sites seguros, pesquisar o nome dos médicos, tudo que eles disseram disso." (H. 16 anos)

"Na hora eu não pensei nada. Depois que vai caindo a ficha, o quê que é, que ia demorar o tratamento. Na hora eu fiquei tão assustada que eu não chorei, não pensei em nada. Câncer, todo mundo tem uma ideia, nossa é a pior doença, dá uma assustada. Eu tinha medo de como ia ser, se eu ia passar muito mal." (I. 17 anos)

Ferreira, De Chico e Hayashi (2005), em estudo qualitativo com adultos com câncer, apontam que o câncer é um nome até hoje dito com cautela, pois retrata uma doença com representações sociais marcantes que refletem o estigma presente até mesmo na menção verbal da palavra, por ser uma doença temida que, apesar dos avanços técnico-científicos alcançados nos últimos anos, ainda deixa sobressair, no senso comum, um significado mortal repleto de sofrimentos. Carvalho (2002) menciona que o câncer pode gerar, ainda, medo da mutilação e da submissão a tratamentos dolorosos.

Conhecer e entender a doença oportuniza aceitar os tratamentos e as intervenções propostas, garantindo maior preparação da criança ou do adolescente, assim como maior envolvimento dos mesmos. 
"Me contaram tudo, não me esconderam nada. Eu acho que isso foi bem legal comigo. Eu ficava conversando e me distraía um pouco." (A. 16 anos) "É melhor saber a verdade, só quem passa pra saber mesmo. É pior se não souber tudo, você fica na dúvida, melhor saber a realidade pra ficar preparado pra próxima." (H. 16 anos)

"Sobre a doença eu pergunto quanto que eu vou fazer de quimioterapia, mas eles não sabem ainda, tem que limpar a medula e enquanto não limpar, não tem como [se refere ao transplante]. Eu penso que eu vou fazer esse transplante, vou me curar e vou viver a minha vida normal. Eles [médicos] falaram que eu tenho que fazer uma megaterapia, que são sete dias de quimioterapia, só que ela é forte, mais forte do que as que eu faço. Depois que eu tiver com tudo zerado, eles me passam o sangue que eles tiraram de mim, da medula e eles põem na veia e vai subindo de novo." (F. 17 anos)

"Eu vou sempre perguntar, saber o que eu to tomando, não tomar qualquer coisa sem saber o que é." (J. 18 anos)

Em estudo de Alcoser e Rodgers (2003), onde se descrevem estratégias de tratamento do câncer infantil, identificou-se que o desenvolvimento físico e psicológico, a educação e o crescimento de uma criança saudável são alterados significativamente diante do tratamento quimioterápico para o câncer. A criança passa a lidar com os efeitos colaterais da doença, tais como dor, perda de cabelo, mudanças corporais, náuseas, vômitos, lesões na mucosa oral, infecções, cirurgias, hospitalizações prolongadas, procedimentos dolorosos, isolamento social, dentre outros. Desta forma, é importante prepará-la para o tratamento, efeitos colaterais e procedimentos de maneira apropriada para a idade.

A literatura tem mostrado que conhecer o diagnóstico traz para a criança maior ajustamento psicossocial, pois ao compreender a doença, ela pode participar de forma mais ativa de seu tratamento (LEMOS; LIMA; MELLO, 2004; VALLE, 1997).

Doente e família, geralmente, iniciam esta etapa com ideias preconcebidas, muitas vezes errôneas, as quais prejudicam este momento, gerando medo, preocupações, atitudes negativas e estresse emocional. Orientações, esclarecimentos e informações, a respeito de cada momento vivenciado pelo doente e sua família, são essenciais nesta fase (LOURENÇO; COSTA, 2000).

Em estudo objetivando descrever sentimentos e reações da família de doentes que realizam quimioterapia, observou-se que, para estes familiares, a orientação e o 
esclarecimento das dúvidas dos doentes quanto à doença e ao tratamento, de forma carinhosa e paciente por parte dos profissionais, é de fundamental importância para ajudar e confortar o doente em todo o processo (SOUZA; SANTO, 2008).

A fim de investigar as informações necessárias aos pacientes que realizam tratamento quimioterápico, em estudo realizado no Reino Unido, McCaughan e Thompson (2000) afirmam que os pacientes com câncer necessitam e demandam informações não somente quanto ao conhecimento da doença e do tratamento, mas também para prepará-los para as mudanças de estilo de vida e para as incertezas inerentes do diagnóstico, visto que a informação resulta em redução de ansiedade e ajuda os pacientes com o seu próprio cuidado, no controle das situações e na utilização dos mecanismos de enfrentamento.

Os pais, quando orientados, podem ajudar no cuidado das crianças e deixálas mais calmas e controladas. A tranquilidade dos pais pode ajudar a aliviar a ansiedade nas crianças, o medo dos procedimentos dolorosos e o desconhecido (THOMPSON, 2003).

Segundo Van Der Molen (2000), objetivando determinar questões importantes para as pessoas com câncer, os pacientes, frequentemente, expressaram descontentamento com a qualidade das informações recebidas. A falta de informação e orientação ou informações distorcidas acerca da situação que vivenciam dificulta o processo de adaptação (COSTA; LIMA, 2002). Para Bashore (2004), é necessária a educação da criança, do adolescente e da família durante todas as fases do processo diagnóstico e terapêutico.

Percebemos que as dúvidas apresentadas pelas crianças ou adolescentes são sanadas pontualmente, conforme vão surgindo, no decorrer do tratamento. Primeiramente os pais e posteriormente os médicos de maior vínculo são os requisitados para solucionar as dúvidas. A doença ainda é entendida pelas crianças a partir de livros e da internet que ajuda a esclarecer algumas questões e até a garantir uma explicação sobre o tema para as crianças, adolescentes e mesmo seus familiares.

"A minha mãe falou [quando perguntou] que a quimio é só um objeto que Deus faz pra gente ver se a gente consegue." (C. 11 anos) 
"Eu procurava mais o Dr. [menciona o nome do médico] porque ele fala tudo, falava certinho, esclarecia tudo, não escondia nada." (A. 16 anos)

"Eu pesquisei muito sobre a doença e pesquisando na internet eu vi coisas que é preferível não ver, você acaba vendo coisas que você não queria receber, casos que não teve cura. Eu li na internet que mais pra frente pode voltar ou dar o câncer em outras partes do corpo. Perguntei pro médico e ele falou que não é pra eu ficar pensando assim, se não eu não vou viver também. Disse que são raros os que voltam, mas é o risco que se corre." (H. 16 anos)

"A psicóloga me deu um livro que tem tudo explicado. Foi bom, eu mostrei pra minha avó, pro meu irmão e eles entenderam o tratamento porque lá explica o que é quimioterapia, o que é rádio, o que é cirurgia, explica tudo." (C. 11 anos)

Em estudo objetivando explorar a experiência de crianças e adolescentes com câncer, Aldiss et al. (2008) referem que, mesmo estando no hospital, os pais são as pessoas mais importantes para as crianças, ficando os médicos e enfermeiros em situações de fundo. Desta forma, a presença dos pais em todos os momentos é muito importante para todas as crianças, sendo procurados para as informações a respeito da doença e do tratamento.

Decker (2007), em estudo de revisão da literatura quanto aos suportes sociais de sobreviventes de câncer infantil, demonstra que, para crianças e adolescentes em idade escolar, a família é considerada a maior fonte de suporte, sendo os pais a principal fonte de informações sobre a doença e as mães, principalmente, a maior fonte de suporte social.

Adolescentes participantes do estudo relataram que a visão da doença sofreu alterações no transcorrer do processo e que, com o avanço do tratamento, se apegaram aos indicadores de bom prognóstico, mostrando com isso, acreditarem na possibilidade de cura, mesmo com as dificuldades encontradas.

"No começo foi difícil porque a palavra câncer é forte, você fala câncer, pessoal fala morreu, acabou, mas não é bem assim, você acaba vendo que não é bem assim, tem cura, muitos anos de vida ainda. Tem muito tratamento, a medicina está muito avançada. Antes falava câncer, morria, acabou a vida, não vai ter mais nada, não vai mais trabalhar, acabou. Hoje não, eu vi o depoimento das pessoas que estão curadas." (H. 16 anos) 
"Eu me sinto muito bem, calmo, é um tratamento. É uma doença que se não tratar ela vai mesmo, acho que toma conta, só que com o tratamento é muito tranquilo, é como se fosse uma doença qualquer, tudo normal. Não sabia o quê que era, falava de câncer, falava de morte. Hoje eu tenho outra imagem, eu sei que tem muitos tipos de câncer, tipos de tumores, tipos de linfomas, então não são tudo a mesma coisa, cada caso é um caso." (J. 18 anos)

Apesar de enxergarem resultados satisfatórios com o tratamento, um dos participantes ressaltou a necessidade de muita força e determinação, fato este que pode não ocorrer com determinadas pessoas.

"Na época mexeu um pouco, lógico, mas não é nada que a gente fala que é insuportável. Tem pessoas que realmente a gente olha e fala que se cair numa dessas, não aguenta." (J. 18 anos)

Adolescentes mencionaram que a intensidade do impacto está intimamente ligada aos preconceitos acerca do câncer, sendo menor quando desconhecido o nível de gravidade do caso. Um participante, se pudesse escolher, teria manifestado a doença em um período de sua infância que não the permitisse entender a gravidade ou as dificuldades do dia a dia com a doença, poupando, desta forma, um sofrimento de grande amplitude. Assim, não lembrar e não entender, para o adolescente, seria um ganho pessoal no auxílio contra a doença.

"Quando eu fiquei doente, eu nem tive medo por causa que eu não tinha a noção do grau. Eu pensava em quanto a medicina está avançada nos últimos tempos. Não tinha muita noção das coisas." (E. 15 anos)

"Eu não queixo muito não, eu só falo que podia ter acontecido isso quando eu era criança pra eu não lembrar disso. Eu acho que quando era nenezinho porque é ruim, é chato, é tudo, eu não sei explicar. É um tratamento muito forte." (F. 17 anos) 


\subsection{A QUIMIOTERAPIA}

\subsubsection{Impacto do tratamento}

O tratamento é iniciado tão logo o diagnóstico é confirmado. A quimioterapia, frequentemente presente entre as formas de tratamento do câncer infanto-juvenil, é lembrada por seus efeitos colaterais e por causar, geralmente, mal-estar. As ideias preconcebidas deixam o doente apreensivo, visto que, até o início do tratamento, eles ainda não têm a real dimensão do que lhes acontecerá ou de como reagirão.

"Que eu ia ficar passando mal também [pensou]. Eu passei mal, mas foi uns dois dias só, foi muito pouco. O tratamento é cansativo porque tem que vir, demora, a gente tem que tomar um monte de cuidado, tem que mudar um monte de coisas." (I. 17 anos)

"Eu perguntei: Como é que é, como faz? Me respondeu: 'Você vai internar, a mesma coisa, tomar um remédio, só que é meio forte, você vai se sentir mal, vai cair cabelo. Quer que eu raspe seu cabelo?' Falei: Não, deixa cair sozinho, até lá fico com cabelo, só que não caiu ainda." (J. 18 anos)

O tempo decorrente entre o diagnóstico e o tratamento, pela necessidade emergente, pode ser muito curto e, rapidamente, antes de se adaptar à doença e compreender $\circ$ processo que vivenciará, a criança e o adolescente já se veem obrigados a realizar o tratamento quimioterápico.

"Já internou sem saber nada e já colocaram remédio em mim. Aí foram falando: 'Você iá fez quimio?' Eu não entendia nada disso." (A. 16 anos)

"Fiquei uma semana com febre e dor de garganta, então eu fiz o exame de sangue, acharam que era mononucleose, depois fizeram o mielograma. Vim direto pro hospital e na mesma hora que descobriram, mais duas horas depois eu já estava aqui fazendo quimioterapia." (E. 15 anos)

Algumas das crianças manifestaram descontentamento diante de situações inerentes ao tratamento, como a hospitalização e a submissão a procedimentos até então desconhecidos, se expressando por meio do choro. 
"Eu não sabia o que era, eu fiquei quieta, aí o meu pai foi me explicar que tinha que fazer cirurgia, que o cabelo ia cair e eu ia ficar mais no hospital até acabar o tratamento, cinco anos. Eu comecei chorar porque eu nunca internei, desde quando eu era pequena, nunca tomei soro, tomava soro por boca mesmo e depois falou que eu ia ficar mais no hospital, aí acabou, vou ter que viver no hospital, morar no hospital." (C. 11 anos)

"O que eu achei? Nada legal, não sabia o que era isso. Me falaram que tinha que pegar veia, eu não sabia com quê ia pegar, eu vi a agulha e comecei a chorar." (D. 8 anos)

Procurar um atendimento de saúde era, até então, esporádico para os participantes deste estudo. No entanto, a quimioterapia trouxe à criança e ao adolescente a necessidade de isolamento, o que provocou a separação de familiares e o convívio frequente com unidades hospitalares, ocasionando, além do impacto da terapêutica, o impacto da internação.

"Antes, quando eu não tinha isso, era muito difícil colher um sangue, muito difícil. Quando a minha mãe me levava no postinho e eu tava com uma diarreia, eles colhiam o sangue, eu tomava sorinho por boca, agora não, toda vez que vem, tem que colher sangue, chegar lá em cima, pegar uma veia, pegar no cateter e todo dia fica colhendo sangue pra ver como que está." (C. 11 anos)

"Pensei que era um soro, um medicamento que tomava e ia embora, só que aí teve que internar! A primeira internação eu fiquei um mês, eu tive que passar o Natal aqui com o meu pai porque a minha mãe foi pra ganhar neném. Foi ruim, eu queria estar na minha casa no Natal, só que eu não estava lá. Eu começo a chorar porque eu não quero vir, eu quero ficar só lá [em casa.] Eu fico triste porque eu vejo meu irmão chorar. Ele fica pedindo pra minha mãe levar ele também, minha mãe fala que se pudesse, ela levava." (C. 11 anos)

"Fiquei bastante tempo internada. Todo mundo da minha casa foi me visitar e depois eu fui embora. Passou uns dias, eu voltei e internei pra fazer a quimio. Aí eu voltava pra casa e ficava três semanas, voltava e fazia quimio." (D. 8 anos)

O isolamento da criança e do adolescente é intensificado em certos períodos pós-quimioterapia. Além do fato de terem restrição de visitas com a finalidade de prevenir possíveis infecções, ainda deixam de frequentar determinados locais que até 
então estavam acostumados, como ir à escola, locais fechados com algomeração de pessoas e outros.

"Ficou meio ruim também por causa que eu não estou mais vendo quase ninguém, ninguém pode ir lá na minha casa. Está meio difícil me comunicar com eles, só pelo celular. (A. 16 anos)

"Quando tem uma festa lá na minha cidade, meu irmão liga e fala que tem uma festa, aí eu fico doidinha pedindo pros médicos me liberarem que eu quero ir, aí tem vez que dá pra liberar, mas tem vez que não dá não." (C. 11 anos)

Segundo Moody et al. (2006), muitas vezes, as crianças são isoladas devido a neutropenias severas, tanto nos hospitais quanto em casa, o que as levam a ter sentimentos de solidão e se sentirem entediadas por terem, por vezes, que ficar o dia todo na cama.

Almeida (2005), objetivando compreender os sentimentos da criança com câncer quanto à sua doença e à hospitalização, aponta que crianças hospitalizadas, na faixa etária de dois a cinco anos, mencionaram, em sessões de brinquedo terapêutico, a falta de familiares, vizinhos, amigos, objetos de casa e animais de estimação. Dramatizaram, por meio da brincadeira, situações da rotina familiar, hábitos e atividades até então realizadas em seu cotidiano, destacando a alteração das atividades do dia a dia. Ainda a partir das brincadeiras, as crianças tentaram destruir os brinquedos relacionados ao hospital e mostraram força e raiva pelos mesmos, refletindo a expressão de força comumente usada pelos pais e profissionais, ao conter as crianças para os procedimentos.

A própria criança doente cria estratégias que possam agradar aos familiares, estratégias que os façam acreditar estar ajudando.

"Teve uma vez que eu menti pra ele [irmão], eu falei: Eu vou internar, vamos comigo? Ele falou que sim e ele veio comigo, mas era só retorno. Aí a médica falou: 'Nossa C., seu irmãozinho veio, agora não vai ter jeito de você internar, você vai ter que ir embora.' Eu cheguei em casa, ele começou a rir: 'Ta vendo Táta, toda vez que você for internar eu vou com você, aí eles não deixam você internar porque eu vou estar junto e como é que vai internar você?' [risos]" (C. 11 anos) 
O hospital é encarado como um lugar não desejado, aceitável apenas quando não há outra possibilidade para a melhora do seu quadro.

"Eu não quero nunca mais ficar internado, só se for muito preciso, caso contrário, não me pede pra ficar no hospital, que eu não fico. Nunca mais ficar no hospital, aqui nunca mais." (B. 13 anos)

"É horrível, fiquei 42 dias [internado] da primeira vez e depois fiquei mais 12 depois que descobriu o tratamento. A gente fica um dia trancado em casa quando chove e nossa, tem gente que fica internado e fica 42 dias num hospital tomando remédio, não pode ir pra lado nenhum, então isso é difícil. Eu fiquei algumas vezes, mas eu não gosto de ficar internado não." (J. 18 anos)

Moreira (2002), em estudo para facilitar a reinserção escolar de portadores de câncer, por meio de esclarecimentos sobre a doença, tratamento e possibilidades de cura, realizado com crianças e adolescentes entre cinco e 11 anos, aponta a hospitalização como uma situação estressante, para a criança e a família, que poderá se refletir no futuro, a depender do tempo e frequência da hospitalização, da gravidade da doença, dos procedimentos médicos, da capacidade de adaptação, do nível de desenvolvimento físico, cognitivo e emocional e do relacionamento familiar, entre outros.

Apesar de representar um lugar de restrições e isolamento, o hospital passa a ser mais tolerado e aceito pelas crianças e adolescentes, visto que a partir dele se torna possível a elucidação do diagnóstico e a realização do tratamento proposto.

"Quando eu tenho que voltar pra cá eu acho ruim, mas tem que fazer o tratamento." (F. 17 anos)

"Eu nunca tinha ficado internada. Pra mim, nossa, comecei a chorar quando ele falou que eu ia ficar internada. Pra mim eu não estava sentindo nada, eu só estava amarela e ele falou que eu ia ter que ficar internada, eu já assustei. Fez os exames pra ver se era hepatite ou não, mas viram uma manchinha no meu fígado e mandaram a gente ir pra um centro maior e foi aqui $[H C]$ que descobriu." (I. 17 anos)

Os sentimentos quanto ao hospital são os mais diversos, desde crianças que não referem preocupações até os que referiram preocupações com situações particulares, como injeções (ALDISS et al., 2008). 
Observamos, nos relatos das crianças e dos adolescentes, o detalhamento dos procedimentos ligados à realização da quimioterapia, seja mielograma, punções venosas periféricas ou de cateter.

"Eles colocam uma agulha aqui no osso e tira o líquido da medula, aí eles veem lá no microscópio pra ver se desapareceu. Ele é ruinzinho porque dá uma anestesia na carne e fica prensando pra atravessar o osso, mas não dói muito." (F. 17 anos)

"Ele colhe o sangue primeiro e vê se o sangue está bom. Se o sangue estiver bom, eu vou pra sala de cirurgia, aí em uma hora e meia eles colocam [refere-se ao cateter]. Eles abrem, dá um ponto aqui no pescoço, ele solta um fio, dão uns três pontos pra não ficar picando, aí aqui só passa uma pomadinha e põe a agulha, uma pomadinha pra anestesiar." (C. 11 anos)

"São chatos esses [intratecal e mielograma]. O mais legal é tirar sangue porque é rapidinho, não demora. É mais chato esse porque tem que ficar lá bastante tempo mexendo a agulha dentro de mim. O outro também, a agulha é pequenininha, mas eles enfiam tudo e dói." (D. 8 anos)

Apesar de corriqueiros, alguns procedimentos são encarados com muito medo pelas crianças e adolescentes, como é o caso das punções venosas. Dizer que já estão acostumados é tido como um afronta para eles, visto que, como eles mesmos relatam, não é possível acostumar-se com algo doloroso e indesejável.

"Eu tenho muito medo de agulha e tem gente que fala: 'Você já até acostumou, pode levar um monte de picadinha que já até acostumou'. Eu acostumei? Não é em vocês. Não acostumei nada, dói ficar picando a gente. Toda vez que pega uma veia, estoura, aí vai picando e por último acha uma no pescoço. Eu não gosto que pega no pescoço porque eu fico com o pescoço duro de medo de perder. Eu fiquei 20 dias com uma veia no pescoço e fiquei com o pescoço durinho, depois eu não conseguia nem mexer. É ruim porque eu fui colher sangue agora, eu pensei que ia ser uma picadinha só, mas ela teve que picar, cotucar e ainda não achou, teve que pegar outra." (C. 11 anos)

"Eu não gosto, é ruim fazer quimio, não gosto de ver agulha, eu tenho medo de ver agulha. Fico sentado, odeio ver agulha, odeio a picada, odeio tudo, tenho pavor de agulha. Eu começo ver, me dá batedeira, o coração dispara. O coração está meio disparado por causa da quimio. Daqui a pouco passa isso aqui. Eu tenho medo, eu não gosto, detesto fazer quimio." (B. 13 anos) 
Moody et al. (2006) destacam as agulhas como a principal reclamação de crianças e adolescentes e apesar de muitas crianças reconhecerem os cremes com anestésicos locais, utilizados antes dos procedimentos, e os cateteres de longa permanência como importantes para amenizar o desconforto com os procedimentos, estes ainda foram vistos como traumáticos, sendo marcante o desejo da exclusão das agulhas.

A dor sentida, durante os procedimentos invasivos, reforça sentimentos de medo, inclusive medo da morte.

"Eu fiz só que doeu, tinha que fazer eu fiz, é, como chama? É aqui, doeu bastante e depois ficou bastante dolorido." (I. 17 anos)

"Até o da medula óssea quando eu fiz da primeira vez doeu pra caramba, aqui do lado que eles fazem. Agora como eles falaram que a minha idade é maior, eles fazem aqui atrás, eles deram uma anestesia e eu estava quase dormindo, eu não senti dor nenhuma, foi suportável." (J. 18 anos)

"Fiz a biópsia da medula no começo da quimioterapia e a biópsia daqui [pescoço], mas a da medula doeu mais, doeu e quebrou a agulha, doeu bastante. Agora já fico pensando, quando eu for curado, vai ter que fazer de novo a biópsia da medula, eu já fico pensando se vai doer porque doía muito medo. Tenho medo de acontecer alguma coisa, eu morrer ali na mesa porque doía muito." (H.16 anos)

A fim de minimizar a dor, o carinho dos profissionais durante a realização dos procedimentos é fundamental para a criança, pois a confiança e $\circ$ vínculo possibilitam que o procedimento seja feito de forma mais tranquila, garantindo maior sucesso.

"Tem vez que eu dou chilique, não deixo tirar [sangue] não, tem que diminuir a agulha [risos]. Outro dia eu fiz 10 exames, dois tubinhos. Faço intratecal e o mielograma, é muito chato tirar sangue, tem vez que é legal, as mocinhas conversam: 'Deixa eu pôr aqui porque se não vai arder, deixa eu pôr a agulha devargarzinho porque se não ela vai chorar.'" (D. 8 anos)

Apesar do medo do adolescente diante dos procedimentos invasivos, é possível que, ao necessitar realizá-lo novamente, ele consiga, por saber como é o procedimento e conhecer a sua função, se sentir mais tranquilo e colaborativo. 
"Eu estou fazendo mielograma, ele [médico] pega e tira um líquido da medula pra ver como está andando o tratamento, se a doença acabou, se ainda tem células mortas. Tiro da coluna, aqui das costas e já tirei da bacia, do lado. Eu já fiz quatro vezes. Estranho porque é um negócio, uma agulha muito grossa, eu acho meio assustador. Não dói, dói um pouco, mas dá anestesia, daí não dói. A primeira vez eu quis ver e passei mal porque eu assustei com a agulha. Duas vezes eu pedi pra fazer dormindo, mas essa quarta vez eu fiz aqui embaixo [ambulatório], aí não tinha como fazer dormindo porque eu tinha que ir embora, aí eu vi de novo, mas aqui foi tudo bom, já sabia o que era." (A. 16 anos)

"Dói bastante, não é aquilo que eu imaginava [mielograma]. Eu passei por isso, você imagina uma coisa, o tamanho da agulha é grande, eu ficava imaginando uma coisa, mas na realidade é outra [risos]. A dor é igual, mas o psicológico é menos, dá pra aguentar." (H. 16 anos)

Vale ressaltar que, com o decorrer do tempo de realização da terapêutica quimioterápica, pelas inúmeras infusões e coletas de sangue necessárias para os exames de acompanhamento, o acesso às veias periféricas tende a ser mais difícil, sendo esta uma das preocupações dos participantes do estudo, pois delas depende a realização do tratamento que possibilita a sua cura. Assim, estar "ruim de veia" é temido pelas crianças e adolescentes, pois o acesso venoso é fundamental para a terapêutica endovenosa.

"As veias sumiram tudo, aí eu pus esse cateter, mas mesmo com o cateter tem que procurar uma veia pra pôr o soro e eu to ruim de veia." (C. 11 anos)

"A veia endurece, aí não pode usar elas mais, fica ruim demais, está muito difícil." (A. 16 anos)

As cirurgias são vistas com esperança, principalmente pela possibilidade de eliminar totalmente o tumor, no entanto, são também temidas pela possibilidade de sequelas permanentes, como nos casos de amputações de membros.

"Aqui em Ribeirão o médico só viu os exames que eu tinha na hora e já falou que tinha que operar, que era um tumor." (B. 13 anos)

"Fiz no dia 04 de abril. A cirurgia é a mais difícil de todas, minha mãe fala que o que é mais difícil é a cirurgia, mas o mais difícil pra mim é a quimio. Lá na minha cidade ele [médico] falou que tinha que amputar, aí eu vim pra cá $[H C]$ e achei que tinha que amputar também. $O$ moço da cirurgia foi me 
buscar pra amputar, mas meu pai não deixou. Primeiro eles falaram: 'Não liga pra isso não, vamos amputar a perna, é normal, tem muita gente que amputa a perna, já tem muleta pra andar, tem cadeira de rodas, tem aquela motinha elétrica.' Aí eu já comecei chorar. Eu nunca tinha visto gente com perna amputada, de ficar sem a perna. la ter que andar só na cadeira de rodas, ir pra escola, os meninos iam ficar rindo." (C. 11 anos)

Decorrentes da terapêutica quimioterápica, de debilitações ou de cirurgias, as internações possibilitam o convívio com outras pessoas, alguns deles desconhecidos e nem sempre da mesma faixa etária. À primeira vista, pelo medo do desconhecido, podem ser encaradas como algo ruim, mas as crianças e os adolescentes vão tendo sua concepção modificada, a partir do convívio com os profissionais e com outros pacientes e familiares, com os quais estabelecem vínculos afetivos.

"No primeiro dia eu cheguei e perguntei se eu ía ficar no meio de todo mundo, só tinha senhor de idade no quarto. Nossa, que hospital ruim, fiquei no meio de todo mundo, mas não imaginava o amor dos médicos que chegava lá, nutricionista, acompanhamento, a dedicação deles. Aí foi me animando, não era aquilo que eu pensava também, que ia ficar internado e jogado num quarto, não era daquele jeito que eu imaginava. Se você falar pra mim hoje, tem que internar pra fazer os exames ou tem que internar por alguma coisa, não vai ser igual a antes, eu vou internar numa boa. Antes cheguei até a chorar, de medo, não sabe o ambiente, como é que é, mas é bem diferente." (H. 16 anos)

"Agora eu já acostumei. A hora que o médico fala que tem que internar, eu já subo lá [enfermaria pediátrica]. No começo eu chorava, esperneava, meu pai ia me puxando pra subir lá pro quarto e eu chorando. Chegava lá eu só ficava chorando, chorando, querendo o meu irmão. Aí ele veio e quando ele ficou vindo, eu acostumei." (C. 11 anos)

Em nosso estudo, observamos que quando facilitada a afinidade entre os companheiros de quarto, sejam eles principalmente da mesma faixa etária, a internação torna-se mais agradável, justamente pela distração que provocam.

"Eu acho legal, mas às vezes que eu fiquei com criança que chora eu achei meio chato por causa que eu estava com dor de ouvido e dor de cabeça. Algumas vezes foram bem legais porque eu fiquei com gente da minha idade, foi bem legal, mas outras vezes foi meio cansativo." (A. 16 anos)

Por se tratar de um centro de referência para muitas outras cidades, encontram-se em tratamento crianças e adolescentes oriundos de cidades distantes, 
de outros estados, inclusive. Com isso, os municípios de origem dos doentes são solicitados a colaborarem com o transporte destes para a cidade de tratamento. Assim, a fim de transportarem os diversos pacientes que realizam tratamento em cidades que fazem parte do trajeto ou no mesmo local (HCFMRP - USP), crianças, adolescentes e seus familiares vivenciam o transporte coletivo em ônibus ou ambulâncias, tendo o tempo para o retorno para casa e seus itinerários aumentados. Ainda que debilitados e cansados, os participantes do estudo mencionam aguardar o transporte, conforme a disponibilidade do município.

"Eu estava de ônibus, aí o médico falou que eu não podia vir de ônibus mais. Minha mãe teve que ir lá conversar com a assistente social da minha cidade, aí me passaram pra ambulância." (C. 11 anos)

"Bom, pela prefeitura tem um ônibus que traz se eu achar melhor vir de ônibus; se eu achar melhor vir de ambulância, marca um dia antes, aí vem de ambulância. Tem também um colega que me traz quando ele está disponível." (J. 18 anos)

Um adolescente menciona que, caso não se sinta bem após a quimioterapia, costuma aguardar a sua melhora antes de sair sozinho e adota medidas preventivas para não sujar o seu meio de transporte.

"Não me acompanha porque ela [mãe] está no trabalho, eu venho sempre sozinho, assino sozinho, vou embora sozinho. As pessoas perguntam pra mim se eu não tenho medo de passar mal no meio da rua. Não, eu não tenho medo porque os médicos tão sempre por perto, se eu passar mal, eles sabem que eu to sozinho. Quando eu to no ônibus eu me previno, levo sempre uma sacolinha comigo para se eu passar mal e vomitar, pelo menos eu não sujo o ônibus. Quando alguém me traz de carro e me leva também, eu levo a sacolinha pra prevenir isso. Se às vezes eu for atravessar e rua e estiver com tontura, passando mal, eu sento e espero, mas eu nunca senti isso, só os vômitos mesmo." (J. 18 anos)

As brincadeiras, em decorrência da terapêutica vivenciada, tornam-se restritas e geralmente as de maior impacto físico, como esconde-esconde e pega-pega são extintas do seu dia a dia. Sair para brincar com os amigos passa a não fazer mais parte da rotina da criança ou do adolescente.

"Eu não posso mais fazer educação física, brincar com os meus amigos do jeito que eu brincava, brincar de esconde-esconde, eu não posso correr ou 
brincar de agacha moleque, que nós inventamos. Ela [mãe] não deixa eu brincar na rua, não deixa eu brincar com os meus amiguinhos, nem dentro de casa, nem na rua, ela é chata às vezes." (D. 8 anos)

"Saía pra rua o dia inteiro. Minha mãe e meu pai trabalhavam e eu ficava o dia inteiro fora de casa, até eles chegarem. Depois ia jogar bola com os meus colegas, agora não mais." (B. 13 anos)

"O que incomoda é que eu não posso fazer as minhas coisas, que eu gostava de fazer como jogar bola, passear, correr, essas coisas eu não posso fazer! Não to indo trabalhar, eu trabalhava." (F 17 anos)

Aldiss et al. (2008) apontam limitações decorrentes da doença e do tratamento das crianças para com suas atividades, como a realização de alguns esportes, ir à escola e ver os amigos. Segundo Moody et al. (2006), as crianças mencionaram o desejo de fazer o que outras crianças fazem como ir à escola, fazer novos amigos, ir ao shopping e se graduar com a turma delas.

Necessitam ainda deixar de brincar com seus animais pelo risco de adquirirem alguma doença, visto que há queda de sua imunidade em determinados períodos do tratamento, privando-os mais uma vez.

"Eu tenho que tomar mais cuidado com as coisas que eu como, tive que parar de pegar nos animais que eu tenho, tem que usar máscara, não pode ter ninguém doente perto de mim." (A. 16 anos)

"Não pode ter animal, não é de qualquer jeito." (J. 18 anos)

Quando internadas ou aguardando atendimento ambulatorial, as atividades lúdicas são muito bem aceitas, em virtude da distração que proporcionam ao evitar pensamentos sobre a doença e ampliar o leque de sensações positivas vivenciadas pelas crianças ou adolescentes. Observamos algumas brincadeiras entre os companheiros das enfermarias, assim como o compartilhamento das histórias vivenciadas e o apoio encontrado a partir da identificação com o colega.

"Podia ter alguma pessoa lá dentro [enfermaria] pra fazer a gente alegrar porque não tem ninguém. Você fica parado lá assistindo televisão, fazendo nada, olhando pra sua mão, tá lá a veia, tá correndo a quimio, gosto de brincar com o meu psicólogo, com você e passar pelo médico pra ir embora [risos]." (D. 8 anos) 
"Me distrair com alguma coisa é bem legal." (A. 16 anos)

"Alguma coisa que é bom é a professora que dá aula e as pessoas que vão lá [enfermaria] brincar, igual você e aquelas que vão lá pra pintar. De segunda e quarta vem uma moça pra dar pintura e jogar joguinho. Eu gosto de pintar, mas toda vez que ela vai lá eu to passando mal. Aí eu perguntei pra minha mãe por que isso não pode ser todo dia pras crianças, pintar todo dia pra distrair. Mas é só de segunda e quarta e toda segunda e quarta eu tô fazendo quimio e eu passo mal." (C. 11 anos)

"Quando a psicóloga não tá conversando comigo, eu durmo ou assisto televisão. Não tem como mudar. A única coisa que pode fazer mesmo ou é ver uma revista ou assistir televisão, ouvir no celular mesmo, não tem outra. Não tem como fazer atividade com uma mão só, não dá pra fazer nada! Que nem eu que sou canhoto, não dá pra fazer atividade nenhuma." (J. 18 anos)

Concordando com o relato acima, Pedro et al. (2007), em estudo brasileiro para compreender a experiência do brincar para a criança e seu acompanhante, na sala de espera, apontam que uma boa estratégia para melhorar a disposição das crianças, enquanto esperam atendimento médico, é o uso de atividades recreacionais, visto que tal intervenção propicia um ambiente descontraído e alegre, ao minimizar os sentimentos negativos envolvidos no processo e ao garantir maior interação com os profissionais.

Moody et al. (2006) apontam, dentre as sugestões para melhorar esta situação, os pedidos de crianças por lugares mais decorados, com pôster, flores e plantas nos hospitais, revistas para adolescentes, sala de música, uma sala para adolescentes e mais crianças na sala de jogos.

Schneider e Hood (2007), objetivando explorar a realidade virtual como uma intervenção de distração para aliviar sintomas de angústia em adultos que realizavam quimioterapia, relataram que, quando submetidos à realidade virtual, técnica que simula a partir de um dispositivo de computador, um cenário como museus e outros ambientes com estímulos visuais e auditivos, conforme manipulação, os mesmos referiram alteração da percepção de tempo. A realidade virtual favoreceu a percepção de um tratamento mais curto e melhor que os tratamentos realizados sem a intervenção de distração. Apesar das experiências positivas não resultarem em decréscimo dos sintomas de angústia, favoreceram a ideia de que a realidade virtual 
pode ajudar a tornar a quimioterapia mais tolerável sem, no entanto, melhorar os sintomas relacionados à mesma.

Em estudo nos EUA, para avaliar os efeitos de óculos de realidade virtual aplicados em adolescentes durante as punções lombares, observou-se que, embora as taxas de dor segundo a escala visual proposta não tenha apresentado estatísticas diferentes entre o grupo de adolescentes submetidos e o grupo de controle, a escala apresentou tendência a ser menor entre os adolescentes submetidos à realidade virtual, haja vista que a maioria dos adolescentes referiu que a realidade virtual ajudou a distraí-los, durante as punções (WINT et al., 2002).

Se não estiverem internados, a necessidade de distração continua, afinal, o maior número de atividades que propiciem o esquecimento da doença ou a sua passagem de forma mais rápida é prontamente buscado pelos adolescentes.

"Tem que terminar logo, já que começou tem que terminar logo. Eu escrevo, faço umas histórias, jogo videogame, assisto filme, saio com meus colegas pra conversar, vou pra casa da namorada pra passar o mais rápido possível. Quando eu comecei ia ter que fazer oito ciclos de quimio, falei nossa, vai demorar, já estou na quinta, eu estou terminando a quinta e vamos embora pra sexta, o que significa que está passando do jeito que eu queria também." (J. 18 anos)

Mudanças relacionadas a atitudes comportamentais aparecem principalmente quando as internações tornam-se prolongadas e os resultados não se mostram muito satisfatórios ou ainda devido às sensações físicas da terapêutica. O aumento da irritablidade ou mesmo a diminuição da comunicação mostram-se presentes, e os membros mais próximos são os mais atingidos pelas reações das crianças e dos adolescentes. A revolta é outra reação que se apresenta, também, nos momentos de definição do diagnóstico e do tratamento.

"Eu fico estressada, bato na minha prima, no meu primo, xingo minha mãe [risos], bato nela, brigo com ela. Quando eu levanto com o cabelo arrepiado ela já sabe que eu tô um veneno [risos]." (D. 8 anos)

"Bom não é mesmo, o primeiro dia dos três seguidos é o mais terrível, chego em casa e vou tentar dormir pra passar o dia logo, dá vontade de chorar e não conversar. Eu falo que, se me chamarem é pra falar que eu não tô, que eu tô dormindo, não consigo conversar com ninguém." (J. 18 anos) 
Com relação às respostas emocionais, Moody et al. (2006) apontam que o estresse foi expresso tanto por crianças quanto por adolescentes, porém de maneiras diferentes. Crianças mais jovens reportaram sentimentos de raiva sobre ter câncer e, apesar da idade, veem a seriedade da doença.

Schultz et al. (2007), ao comparar sobreviventes de câncer e irmãos de sobreviventes para determinar a incidência de dificuldades em determinados domínios comportamentais e sociais (depressão, ansiedade, déficit de atenção e outros), observaram que os sobreviventes do câncer possuem mais sintomas de depressão e ansiedade (1,5 vez mais que os irmãos), além de comportamentos antissociais (1,7 vez mais). Os índices de depressão, ansiedade e déficit de atenção foram significativamente mais elevados em adolescentes tratados com leucemia e tumores do SNC, em comparação com seus irmãos. Assim, adolescentes sobreviventes do câncer infantil, especialmente com história de leucemia, tumores do SNC ou neuroblastoma podem ter maiores riscos para comportamentos adversos, o que pode necessitar de estratégias prioritárias.

Liang et al. (2008), em um estudo em Taiwan para comparar problemas emocionais e comportamentais de crianças com câncer que estavam frequentando a escola com um grupo-controle de crianças saudáveis do mesmo nível escolar e sala de aula, mesmo sexo e condições socioeconômicas e sem histórico de doença crônica na família, apontam, a partir do levantamento de dados de pais e professores destes dois grupos, que as crianças com câncer apresentam maior incidência de problemas sociocomportamentais, como introversão e depressão, problemas sociais, hiperatividade e impulsividade, comportamentos agressivos e outros, mostrando ainda a necessidade de cuidados psicossociais para as familiares de crianças com câncer. No entanto, em uma revisão da literatura para investigar as intervenções psicossociais para adolescentes com câncer, concluiu-se que as intervenções são raras, o que evidencia a necessidade de futuras pesquisas de intervenção junto a este grupo (SEITZ et al., 2008).

Da mesma forma, Buizer et al. (2006), para avaliar problemas comportamentais e educacionais de sobreviventes de câncer infantil (LLA ou Tumor de Wilms) com menos de um ano após o término da quimioterapia, os compararam com outros dois grupos, o de seus irmãos saudáveis que experienciaram a angústia emocional de um membro 
familiar doente e outro com crianças saudáveis da mesma idade, seus colegas de escola. Pais e professores também participaram das questões levantadas para a pesquisa. Os resultados mostraram um risco aumentado de problemas comportamentais e educacionais, com menor performance escolar em sobreviventes de LLA, comparado com seus pares do grupo de crianças saudáveis, da mesma idade. No entanto, não foram encontradas indicações de limitações comportamentais ou educacionais de sobreviventes de tumor de Wilms ou em irmãos de sobreviventes.

Da mesma forma, Moore et al. (2003) mencionam que crianças e adolescentes que estão recebendo ou completaram o tratamento para LLA podem apresentar riscos para problemas de ajuste comportamental, internalizar problemas como somatização, depressão, ansiedade e introversão. Yeh (2002) conclui que, apesar de aumentar o número de sobreviventes do câncer infantil, os efeitos colaterais decorrentes de protocolos prolongados e exaustivos causam sofrimento nas crianças, ultrapassando a esfera física e atingindo o âmbito psicológico.

A frequência escolar, até então diária na rotina das crianças e adolescentes, passa a ser menos presente, visto que os mesmos dependem de autorização dos médicos para o retorno às aulas, a depender da fase do tratamento em que se encontram e das suas condições de saúde, mudando completamente o dia a dia. A impossibilidade de frequentar a escola prejudica o rendimento escolar.

"Eu vou quando eu não estou fazendo quimio [se refere à escola]. Quando o sangue cai eu não vou também." (E. 15 anos)

"Eu tive que parar a faculdade e estou longe de todos, todos os meus amigos estão lá e eu to aqui só com a minha mãe, tó todo mundo pra lá." (l. 17 anos)

"Algumas coisas mudaram, eu não vou mais à escola e tem que ficar internada. Os amigos da escola eu não vejo mais." (G. 15 anos)

"Na escola eu ia normal, agora se eu for pra escola eu tenho que ir de máscara e tenho que passar álcool na mão pra desinfetar se eu pegar em alguma coisa suja." (A. 16 anos)

"Só estudo aqui no hospital mesmo. A minha mãe sempre vai na escola e busca as matérias pra mim, traz aqui e aí a professora daqui explica. Lá na minha cidade não tem isso, se ficar internada, fica sem escola, mas aqui não, aqui já é diferente." (C. 11 anos) 
"Eles estão levando uns trabalhos em casa, alguns professores não estão me mandando trabalho e já estão saindo minhas notas. Eu acho ruim por causa que não tem como saber, mostrar o que eu sei, aprender o que eu quero porque fica difícil aprender em casa, sem professor, sem nada, fica ruim." (A. 16 anos)

Em revisão da literatura objetivando investigar as ausências escolares, problemas comportamentais e relacionamentos sociais de crianças com câncer no retorno à escola, no Reino Unido, Vance e Eiser (2002) apontam que as ausências escolares são mais frequentes entre crianças com câncer do que entre crianças saudáveis ou com outras condições crônicas, sendo um problema desde a fase de diagnóstico até depois de completado o tratamento.

Shaw e McCabe (2008), em revisão da literatura, apontam que as doenças crônicas se tornaram comuns entre as crianças e têm um impacto profundo na educação destas. A reintegração da criança doente no ambiente escolar necessita de uma equipe multidisciplinar envolvendo médicos, profissionais da escola e os pais, visto que, em decorrência dos efeitos adversos dos tratamentos realizados como a quimioterapia, no caso de crianças com câncer, podem aparecer dificuldades na atenção e memória, além de sequelas cognitivas e irritabilidade. A dor, fadiga e náuseas presentes no processo vivenciado com a doença também limitam as habilidades das crianças e dificultam a frequência escolar. Assim, há necessidade de maior flexibilização das escolas com planos individualizados para os alunos com doenças crônicas que se ajustem às crianças, de acordo com as recomendações médicas e necessidades físicas e socioemocionais. Para Bessel (2001), retornar à escola é, portanto, uma questão-chave, já que requer um bom planejamento e a reintegração da criança, a partir de programas entre a escola, o hospital e os familiares.

Segundo o Decreto-Lei n. 1 1044, de 21 de outubro de 1969 (BRASIL - MEC, 1994), que dispõe sobre o tratamento diferenciado a alunos em certas situações de saúde, crianças com câncer podem ser beneficiadas, possibilitando a realização de exercícios domiciliares como compensação à ausência escolar, desde que acompanhados pela escola e segundo as exigências do sistema oficial de ensino. Há ainda a possibilidade de classes hospitalares que visam a atender as crianças e adolescentes hospitalizados. Para Moreira (2002), com o aumento da sobrevida, as 
crianças e adolescentes desejam voltar à escola, pois percebem que sua ausência limita seu desenvolvimento e sua socialização. A escola, no entanto, precisa aprender a receber estas crianças, visto que não está preparada e não tem conhecimento sobre o tema câncer.

Muitas vezes, a sociedade não está preparada para atender a criança e o adolescente que têm necessidades especiais. Tal fato é apontado pelas crianças, ao relatarem a rejeição da escola para com ela ao referir que esta deve permanecer afastada, mesmo após a autorização da equipe médica.

"la, mas agora eu não tô mais indo [se refere à escola]. Eu gosto muito de estudar. Meus coleguinhas vão à minha casa perguntar quando eu vou pra escola. A doutora me deu um atestado pra levar lá na escola e me deu um comprovante que eu posso estudar, só que minha escola não quis deixar, fala que é perigoso pegar uma infecção, uma virose e que aí eles serão os culpados, falam que não podem aceitar gente assim na escola, aí minha mãe veio aqui, conversou e agora a assistente social vai lá." (C. 11 anos)

Objetivando identificar os fatores de maior estresse experienciados pelas crianças com câncer, McCaffrey (2006) aponta os procedimentos ligados ao tratamento quimioterápico, o ambiente hospitalar, as recaídas e o medo de morrer, além de questões ligadas à imagem corporal, perda da autoestima e assuntos relativos à preparação da transição para a volta ao mundo real, como a escola.

\subsubsection{Características dos quimioterápicos}

A quimioterapia é definida, pelas crianças e adolescentes, assim como a doença, de forma bastante resumida, enfatizando-se principalmente o objetivo da eliminação do tumor para a cura, sendo marcada pelos efeitos adversos que provoca. Para a criança e o adolescente, a quimioterapia é uma combinação de drogas que tanto "matam as células ruins do tumor, como as células boas" e, para compensar este prejuízo, faz-se necessário o que eles mesmos chamam de resgate.

"Ela [quimioterapia] serve pra acabar com as células mortas, mas ela também acaba com algumas boas." (A. 16 anos) 
"Eles escreveram assim no livro, que a quimioterapia é um remédio que põe um monte de droga pra matar o tumor. Enquanto está correndo a quimio, a quimio mata a célula ruim e a célula boa. A célula ruim é a do tumor, mas não mata só o tumor, mata a célula boa, aí eles fazem o resgate pra colocar tudo de novo a célula boa. Essa quimio que eu vou fazer é de tirar células do corpo, depois eu faço o resgate pra colocar elas. Eu só não gosto de resgate porque demora muito, a minha quimio é de um dia, mas o resgate é de duas semanas. O medicamento é forte, não é fraco igual um soro, ele é forte, aí você fica um, dois, três dias vomitando, mas depois passa tudo." (C. 11 anos)

"É um soro que aplica na veia, um remédio para matar as células ruins, só que ela mata as células ruins e mata as células boas também." (B. 13 anos)

"Eu perguntei por que a quimio é forte, ela [mãe] falou: 'Porque o líquido é feito de um negócio muito forte pra poder matar a célula que está doente.' Eu diria que é um líquido que vai dentro do corpo para matar as células que estão doentes." (D. 8 anos)

"Só sei que ela é pra matar a célula ruim e também matam as células boas, por isso que a gente fica indefeso." (F. 17 anos)

"É um remédio pra diminuir o tumor." (G. 15 anos)

"É um monte de drogas. Ela [quimioterapia] acaba destruindo as células boas e as ruins, aí tem os remédios que combatem as ruins e as boas também! Não sei muito bem! Eu sei que cada remédio vai curar uma parte do corpo, parece que toma um comprimido pra combater a quimioterapia." (H. 16 anos)

"É um tratamento químico [risos]. Não sei mais, é um tratamento químico e cada um tem um certo tipo, tem o tratamento químico pra leucemia, linfoma, um monte de coisas, sei que é um tratamento químico." (J. 18 anos)

Vale ressaltar a preocupação das crianças em relatar que a quimioterapia não dói e sim a punção para sua realização, fato que é visto como de grande importância para as crianças.

"Eu entendi que era um líquido que vai muitos remédios e toma pela veia. Não dói, só dói a picada, tava escrito assim [livro que ganhou da psicóloga]." (C. 11 anos) 
As crianças e os adolescentes descrevem características dos quimioterápicos, identificando-os e diferenciando-os com relação à aparência, às sensações apresentadas e aos diversos esquemas terapêuticos.

Os quimioterápicos endovenosos são diferenciados pelas cores. As crianças e adolescentes atribuem à quimioterapia vermelha a maior intensidade e, portanto, a veem como a maior causadora de efeitos colaterais como vômitos e manchas na pele. Em seguida, segundo a concepção das crianças e adolescentes deste estudo, o quimioterápico branco tem menos intensidade e, por fim, o amarelo é o mais fraco, apresentando menos efeitos colaterais.

"A branca, a amarela e a vermelha, são três saquinhos; a vermelha toma um saquinho só porque a vermelha é mais forte. A amarela vomita muito, vomita ela amarelinha. Quando eu faço quimio, pode ser amarela, vermelha ou a branca, eu mijo de cinco em cinco minutos, $500 \mathrm{ml}$. É toda hora, eu só sinto o estômago ruim e a urina sai forte. Ele [médico] falou que a quimio que eu faço é de osso. Eu já acostumei com a branca e a amarela. Com a vermelha eu não acostumei ainda não, ela é forte, eu começo a vomitar e sai mancha." (C. 11 anos)

"Eu tomo um líquido vermelho que é o forte que mata tudo, eu tomo um líquido branco que é meio forte e mata menos, metade e tem um líquido meio amarelo que mata pouquinho. Eu faço de três tipos, a vermelha, a branca e a meio amarela." (D. 8 anos)

Quanto aos quimioterápicos em apresentações de comprimidos, um adolescente menciona perceber efeitos colaterais diferentes dos utilizados via endovenosa. Para ele, os comprimidos causam menos efeitos como náuseas, porém intensificam a manifestação da dor de cabeça, o que atrapalha o sono e o repouso.

"É diferente porque ele [quimioterápico em comprimido] não me dá vômito, mas me dá dor de cabeça e um barulho no ouvido, fica meio assoprando o meu ouvido e é só de um lado. Na de comprimido dá mais, dá mais forte a dor e o barulho, eu fico com insônia, não consigo dormir." (A. 16 anos)

Apesar de não ser bem tolerado pelo adolescente, tendo em vista a necessidade de deglutição dos comprimidos, o mesmo cria estratégias a fim de permitir a sua ingestão, tal como o uso concomitante destes com alimentos bem aceitos, objetivando mascarar o sabor do comprimido. 
"Eu não mastigo ele [quimioterápico em comprimido], eu mastigo uma bolacha, um chocolate e ponho ele quando eu vou engolir, aí eu engulo tudo junto." (A. 16 anos)

Aldiss et al. (2008) observaram que, diante do diagnóstico e do tratamento, as crianças falam pouco sobre a experiência de estarem doentes e do seu tratamento, mas referem-se aos medicamentos usando os nomes técnicos e mencionam aceitálos, se não tiverem gosto ruim. Moody et al. (2006) apontam que as crianças e os adolescentes sugerem que os medicamentos não tenham gosto ruim e que não façam as pessoas se sentirem com náuseas.

As apresentações de comprimidos trazem uma grande vantagem para as crianças que necessitam da quimioterapia, pois além de ter menos efeitos colaterais, garantem o tratamento em seus domicílios, permitem que os pais controlem os horários das medicações, sentindo-se mais responsáveis pela ajuda terapêutica ao filho e promovem uma ideia de maior proximidade com o término do tratamento.

"A mãe de A., enquanto aguardam atendimento médico ambulatorial, oferece um chocolate ao filho e the diz que está na hora de tomar o remédio. Refere-se a um comprimido de quimioterapia, a qual já faz uso em seu domicílio. (Observação - Mãe de A.)

"Já está quase acabando o tratamento, em dezembro o médico falou que acaba e aí vai ser quimio por boca, tomar comprimido. Eu tô doidinha pra chegar dezembro [risos]." (C. 11 anos)

A fim de proporcionar aos pais uma sensação de participação mais ativa no tratamento de seus filhos e de diminuir a frequência de hospitalizações, estudos como - de Close et al. (1995) vêm comparando a administração de agentes quimioterápicos em hospitais e nas casas dos próprios doentes. Após seleção de algumas drogas para a administração no domicílio, como o metotrexato intravenoso, confirmaram-se a redução de custos e um estilo de vida mais satisfatório para crianças e seus pais, além de resultar em menor estresse e um senso de controle maior sobre o cuidado da criança. Concordando com o referido anteriormente, Stevens et al. (2004), em um estudo para determinar as perspectivas de profissionais de saúde da comunidade e de hospitais pediátricos envolvidos em um programa de quimioterapia domiciliar, apontaram benefícios percebidos pela família, tendo em 
vista o impacto positivo no dia a dia e o bem-estar psicológico das crianças e familiares.

Os participantes do estudo relatam, no entanto, que os primeiros dias de quimioterapia endovenosa são os que apresentam mais efeitos colaterais e que, após alguns dias, eles se encontram mais dispostos.

"Eu fiquei enjoada, vomitei, foram só dois dias e um dia que eu não fiquei muito boa, o resto não senti mais nada." (I. 17 anos)

"Dá vômito, essas coisas, mas logo depois eu já não tenho mais nada. Sinto isso, vômito e estômago ruim, aí você senta na ambulância, ela começa a balançar, quando fico ruim eu vou na janela, dá um estômago ruim, dá ânsia, eu não como nada, não pode ser muita coisa porque se não vomita tudo. O corpo fica mole, bobão, no sol os olhos ficam ruins, o estômago dói! Tomo remédio, mas não para, não faz nem efeito, tomo coca. Antes eu comia bastante, agora ta difícil pra comer, passa uma semana eu volto a comer tudo de novo." (B. 13 anos)

"Eu sinto o corpo fraco, fico meio fraco, mas em uma semana já fico melhor, a boca fica ruim também, não sinto muito o gosto da comida, tira o gosto." (F. 17 anos)

Dessa forma, o adolescente é capaz de comparar os ciclos quimioterápicos nas diferentes fases, sendo percebida a utilização de um quimioterápico "mais fraco" na fase de manutenção do tratamento, além de mencionar preferência pelos tratamentos ambulatoriais que possibilitam o retorno à sua casa após a administração.

"A quimioterapia é muito mais fraca [se refere à fase atual do tratamento manutenção]. Eu não podia nem sair de casa, quando dava febre eu tinha que internar uma semana e depois de uma semana eu já voltava pra fazer outra quimioterapia, era difícil. Dá pra ficar em casa depois dela." (E. 15 anos) [se refere à quimioterapia ambulatorial]

Observamos, a partir das análises das entrevistas do estudo em questão, que o efeito colateral é o aspecto mais mencionado pelas crianças e adolescentes, sendo as mudanças físicas, as mais referidas, em razão da sua relação com a autoimagem e a integridade de todo o organismo. 
Para eles, os principais efeitos colaterais são o mal-estar, as náuseas e vômitos, a indisposição, a mucosite, falta de apetite, alteração de peso, dor de cabeça, manchas na pele e alopecia.

"Ela [quimioterapia] tem algumas complicações, uns efeitos que pra mim foram vômito, dor de cabeça, barulho no ouvido. Eu estava sentindo o coração bater mais devagar, eu até vim aqui por causa disso, porque eu estava meio ruim, eu me sentia meio estranho, não sei explicar o que é. Depois e durante [quimioterapia] eu não consigo comer nada, só o vômito, a dor de cabeça, são coisas que sempre acontecem." (A. 16 anos)

"Caiu o cabelo, eu achei que emagreci bastante com a quimio, mas agora eu tô engordando. Dá ferida na boca, meus olhos secaram que não saía lágrima. Eu tive que pingar colírio, as unhas ficaram fracas, com estas listas, fica meio ruim." (A. 16 anos)

"Tem vez que dá vontade de vomitar, mas tem vez que não dá, fica normal. Tem vez que eu não paro de ir ao banheiro, tem que ficar paralisando pra eu ir, eu sento na cadeira e logo quero ir ao banheiro, tem que levar de novo. Tem vez que eu sinto dor nas vistas quando eu chego em casa, aí eu fico deitada só no escuro. Dá vontade de vomitar, tontura, é chato." (D. 8 anos)

"Enjoa, faz doer o estômago, cair o cabelo. Algumas partes escureceram um pouco [pele]." (G. 15 anos)

"Eu não gosto não. Eu falaria que é muito ruim, que cai o cabelo, fica com o organismo fraco, que não pode bater em lugar nenhum que fica roxo, sangra à toínha." (F. 17 anos)

Observamos que os vômitos podem ser encarados como uma das piores manifestações, favorecendo a perda do apetite, já que ao se alimentarem, logo apresentam o vômito, o que pode levar à recusa da alimentação durante esta fase.

"Eu penso, é ruim demais, os vômitos são o que mais, é o mais ruim porque eu seguro pra não vomitar, aí eu não como. Se começo a falar, vêm os eniôos, ainda mais quando começo a falar em comida, aí o estômago começa a embrulhar. A hora que me dá fome, que eu coloco uma coisa na boca, volta tudo de novo, aí eu desanimo e não como mais nada." (C. 11 anos)

A náusea é o desconforto mais frequente relatado (MOODY et al., 2006). Robinson e Carr (2007) mencionam que adultos e crianças expostas a agentes 
quimioterápicos estão sujeitos a apresentar náuseas e vômitos, imediatamente e em casa, nas primeiras semanas após a quimioterapia. $\bigcirc$ pensamento de vomitar após o tratamento é um dos efeitos colaterais mais temidos da quimioterapia e, segundo os autores, crianças ou adolescentes que têm vômitos incontrolados pela quimioterapia têm risco para o desenvolvimento de náuseas e vômitos antecipatórios nos ciclos futuros. O vômito é, portanto, um sintoma angustiante com um significante impacto físico e emocional na criança e no adolescente com câncer que ainda experiencia estresse, fadiga, perda de cabelo e dor, podendo comprometer a qualidade de suas vidas.

Tendo em vista a maior susceptibilidade de crianças e adolescentes para o controle dos efeitos de náuseas e vômitos induzidos pela quimioterapia, vale ressaltar que estudos mostram maior eficácia do granisetron comparado ao metoclopramida e ondansetron, medicações utilizadas na prática diária para o controle de náuseas e vômitos. O granisetron tem maior tempo de duração, sem necessidade de complementação de outras doses orais no período de 24 horas, ao contrário do metoclopramida que apresenta maiores efeitos colaterais como reações extrapiramidais e da ondansetron que, apesar de efetiva e apresentar poucos efeitos colaterais, necessita de mais administrações endovenosas complementadas com doses orais (LUISI et al., 2006).

Em decorrência dos vômitos e das alterações de paladar, a aceitação dos alimentos é fortemente diminuída. Adicionam-se, ainda, a incorporação, na prática domiciliar, de mudanças quanto ao preparo e escolha dos alimentos a serem oferecidos. No entanto, sua aceitação é difícil, o que promove a inclusão de alimentos mais bem aceitos como sorvetes, refrigerantes, frutas e outros.

"Eu esterilizo com um litro de água e uma colher de água sanitária. Você esteriliza a fruta 20 minutos, aí você enxágua bem, tira a casca e come normal. Verdura também." (G. 15 anos)

"Tem que tirar um pouco do sal por causa do corticoide. Minha mãe tem que diminuir o sal também, tem que colocar só uma pitadinha de nada. Não posso comer nada cru, ela esteriliza. O médico liberou o alface e o tomate do jeito que faz a salada, só que o meu tem que esterilizar." (D. 8 anos) 
"Fruta tem que lavar bem e ser tudo cozida ou assada. Um doce que está aberto há dias na geladeira ou um alimento que não tenha a cara boa, que não sabe de onde veio, eu não como. Eu comia essas bactérias, hoje que eu tô vendo o que eu comia, comia uma fruta sem lavar a mão, sem lavar a fruta, comia no supermercado [risos]. Vou mudar isso daqui pra frente, são muitas bactérias que as pessoas ingerem sem perceber." (H. 16 anos)

"Eu consigo tomar refrigerante, tomar sorvete, só isso que eu aceito, o resto, tudo que eu ponho, volta. Eu não gosto da comida do hospital, o cheiro é forte. Eu queria que tivesse uma cantina só pras crianças do câncer, precisa ter uma comida mais leve porque a comida daqui é muito forte, aquelas vasilhas também dão muito cheiro." (C. 11 anos)

"Só comida de hospital eu não consigo comer, o cheiro e o gosto eu não gosto, é meio sonso. Eu como coisas que eu trago de casa, trufa, bolacha [risos]. (G. 15 anos)

Em concordância com os dados desta pesquisa, Moody et al. (2006) mencionam a ocorrência, por parte das crianças e adolescentes, da perda do prazer pela comida devido à perda do apetite, mudanças no gosto e mesmo no cheiro desta, visto a restrição na escolha dos alimentos e os efeitos da quimioterapia. Segundo os autores, as crianças descreveram a comida do hospital como a pior e provocadora de vômito e pediram para melhorá-la, sugerindo comidas sem cheiro e mesmo algumas em particular, não cozidas, como maçãs, sanduíches e pizzas.

Da mesma forma, em estudo realizado em uma unidade oncológica de um hospital da Suécia, a fim de entender as variáveis relacionadas à ingestão de alimentos e os problemas de alimentação de crianças, durante a quimioterapia, elas mencionaram que o gosto alterado dos alimentos é tido como a causa predominante dos problemas alimentares. Já para as enfermeiras participantes do mesmo estudo, as náuseas foram as mais importantes causas dos problemas alimentares. Em adição, os aspectos psicológicos ligados à aversão e as atitudes negativas frente à comida do hospital foram também considerados importantes. Acrescenta-se, ainda, como possíveis causas dos problemas alimentares, a dor pelas mucosites. $O$ cheiro da comida é ainda outra causa de náusea sentida pelas crianças que recebem quimioterapia. Desta forma, parece existir alteração no senso gustativo e na percepção da comida por crianças com câncer submetidas à quimioterapia (SKOLIN et al., 2006). 
Percebemos, neste estudo, que os períodos de quimioterapia são comumente de indisposição. Neste momento, o pedido pelo silêncio, pela não comunicação e por dormir ou assistir à televisão, de forma passiva, é o que se sobressai. As atividades físicas não são bem aceitas no período que mais mencionam os efeitos colaterais do tratamento.

"Fico assistindo televisão [enquanto realiza a quimio]. Quando eu não estou assistindo [televisão], eu fico dormindo." (C. 11 anos)

"Só durmo pra passar o tempo mais rápido." (R. 15 anos)

A fadiga é um sintoma comum, complexo e multidimensional vivenciada pela maioria dos pacientes com câncer, durante o tratamento (LESAGE; PORTENOY, 2002; PORTENOY, 2000). Em estudo de Hockenberry (2004), a fadiga é reportada por adultos jovens com câncer como o mais angustiante sintoma que experienciam desde o diagnóstico até o término do tratamento.

Segundo Hockenberry-Eaton et al. (1998, 1999), as crianças expressam sua percepção da fadiga em relação às mudanças ocorridas nas atividades que desempenhavam antes de ter câncer. Revelam mudanças em suas atividades físicas, por exemplo, na prática de esportes e nas atividades com amigos. As crianças descrevem a fadiga por agora estarem fazendo mais atividades tidas como sedentárias do ponto de vista físico, como assistir à televisão ou ler livros. Descrevem, ainda, períodos nos quais se apresentam com mais fadiga, como nos períodos da manhã e imediatamente após o tratamento. Yeh et al. (2008), em estudo para investigar as relações entre fatores clínicos, como valores de hemoglobina, agentes quimioterápicos e o uso de corticosteroides e mudanças nos padrões de fadiga antes e durante 10 dias do início de um novo ciclo de quimioterapia, em crianças com câncer, identificaram que os pacientes têm mais problemas com fadiga nos primeiros dias depois de iniciar o ciclo quimioterápico. Segundo Stasi et al. (2003), em revisão da literatura, a fadiga esteve presente, no momento de diagnóstico do câncer, em 50 a $75 \%$ dos pacientes, aumentando para 80 a 96\%, quando realizavam quimioterapia.

Perdikaris et al. (2008), em estudo para avaliar as mudanças de escore de fadiga durante o tratamento do câncer e descrever as principais causas de fadiga, a 
partir das perspectivas das crianças, observaram que as meninas demonstraram maiores escores de fadiga que os meninos. Três mensurações foram realizadas para a avaliação, no início, no meio e no fim de cada protocolo de tratamento. As principais causas mencionadas, no primeiro momento, foram os procedimentos médicos, a necessidade de ficarem durante a noite no hospital e o tratamento em si. No segundo momento, as causas foram o tratamento, os procedimentos médicos e a dor. Já durante o terceiro momento de mensuração, as crianças identificaram novamente o tratamento, a necessidade de ficarem a noite no hospital e, por fim, os procedimentos médicos. Tais diferenças de ordem nas diferentes medidas são explicadas pelo processo em questão, como diferenças de intensidade da ação do tratamento, aparecimentos de reações adversas e limitações impostas pelo tratamento. Vale dizer que o ambiente hospitalar é tido como uma frequente causa de fadiga, devido às interrupções do sono e das mudanças nos padrões de sono da criança e do adolescente, já que são incomodados pelos barulhos de celulares e bombas de infusão intravenosa, outros pacientes, atividades dos enfermeiros, fechamento das portas, dentre outros.

Em revisão da literatura, Eddy e Cruz (2007) mencionam que as crianças frequentemente reportam a fadiga como uma interferência que diminui a qualidade de suas vidas, sendo, portanto, sua avaliação e controle essenciais para a melhoria da qualidade de vida das crianças com problemas crônicos de saúde.

Com relação à imagem corporal, os participantes do estudo destacam, principalmente, aspectos ligados à mudança de peso, à alopecia e à necessidade do uso de máscaras cirúrgicas.

Alguns medicamentos, como os corticoides, segundo a visão de um adolescente, são responsáveis pelo aumento do consumo de alimentos.

"Quando eu tava tomando o remédio, a dexametasona, nossa, eu comi uma pratada." (B. 13 anos)

Em contrapartida, o emagrecimento, mais frequente no início, muitas vezes, além de incomodar o próprio adolescente se torna mais marcante, a partir dos comentários de outras pessoas, comentários estes que conferem ao emagrecimento um significado de desgaste decorrido do tratamento. São alterações que influenciam 
a autoimagem das crianças e adolescentes e permitem que as pessoas percebam que algo está acontecendo e interferindo no seu corpo.

"Não era tão gordinha, eu pesava $35 \mathrm{~kg}$, mas depois os outros foram me olhando, não me conheciam mais porque eu fui emagrecendo, fiquei com $26 \mathrm{~kg}$. Os outros me viam e falavam que eu estava magrinha e eu falava que era a quimio. Eles falavam: 'Nossa, mas a quimio derruba tanto assim?' Quando comecei o tratamento, eu não comia nada porque as frutas tinham que ser cozidas e eu não gostava, eu nem gostava de fruta e depois que tinha que cozinhar a fruta, aí que eu não comia mesmo. Eu fiquei bem magrinha, eu achava tão feio magra. Ficava chorando porque antes, quando eu subia na balança, eu sempre estava mais gorda, só subia o peso, aí depois eu subia na balança e ia só diminuindo, era ruim demais." (C. 11 anos)

"No começo eu emagreci bastante. Não foi bom porque eu já sou magrelinha." (I. 17 anos)

Com o caminhar do tratamento, a alimentação vai sendo melhorada, e ganhos tão almejados, como a melhora das mudanças físicas, tornam-se muito importantes para a autoestima dos adolescentes.

"Ele ia me dar um remédio pra se alimentar bem, eu to tomando esse remédio agora e eu to engordando. Cheguei a pesar 26 quilos. Antes desse tratamento eu pesava 35, hoje eu já to com 33 [sorriu]." (C. 11 anos)

Quanto à perda de cabelo, os participantes mencionam não aceitá-la no início, visto que altera fortemente a autoimagem e permite que todos a percebam, causando sofrimento para estas crianças e adolescentes. Nesta fase, utilizam frequentemente, tal como observado entre meninas e meninos, chapéus, bonés e lenços, acessórios que de alguma forma escondem a ausência do cabelo, pois, para eles, a alopecia deixa sobressair uma imagem que o mesmo considera "feia, que o faz perder o charme e assusta entes queridos."

"Eu chorei muito quando o meu cabelo caiu. A primeira vez que eu passei o pente já começou a cair, caiu em dois dias, caiu tudo. Sem cabelo eu acostumei, mas a minha irmã não acostumou não [risos]. Eu tiro o chapeuzinho e ela começa a chorar, se o chapeuzinho cai no chão, eu fico quietinha lá, sem cabelo, aí ela olha e começa a chorar e pega o chapeuzinho no chão e coloca na minha cabeça. Ela não gosta que eu fique sem chapéu, eu acho que ela tem medo [risos]." (C. 11 anos) 
"É o pior, a pior parte é o cabelo que está caindo demais. Eu tinha o cabelo bem grandão, já cortei um monte, está caindo bastante. Eu não tô passando muito mal e o cabelo pra gente, pra menina, perder o cabelo não é fácil. Tudo bem que vai crescer, mas demora. É ruim também você olhar e se ver sem cabelo, é ruim." (I. 17 anos)

"Antes eu era mais bonita, agora tô feia porque eu tô careca. Quando eu tinha cabelo, meu olho ficava assim, bonitinho, colocava o cabelo aqui e ele ia assim, agora carequinha não dá pra pôr. Eu coloco até pano no cabelo pra fingir que é meu cabelo. Minha mãe fica me chamando de coquinho pelado, minha prima fica me chamando de careca, só o meu priminho que me agrada, me chama de cabeluda." (D. 8 anos)

Passado o tempo, quando eles começam a se preocupar com outros aspectos do tratamento, passam a aceitar a queda de cabelo, percebendo que é um evento passageiro e temporário.

"Normal, depois cresce de novo! Caía tudo, você passava a mão assim e saía aquele tufo de cabelo na mão." (B. 13 anos)

"O cabelo é de menos. Se eu tivesse ele, eu tava cuidando dele, eu tinha muito luxo com o meu cabelo, mas se perdeu é porque o tratamento que faz tem que perder mesmo, então o cabelo é o de menos, precisa saúde, depois cabelo." (C. 11 anos)

"Eu comecei a fazer o tratamento e revoltei um pouco por saber que o cabelo ia cair, depois foi passando, eu vi que o cabelo veio crescendo, aí melhorou. Chorei um pouco, depois passou." (G. 15 anos)

"No primeiro dia quando começa a cair o cabelo é difícil, eu chorei porque estava caindo o meu cabelo, depois eu me acostumei com a ideia, não ligo mais não." (J. 18 anos)

Segundo a literatura, a alopecia tem implicações psicossociais, visto que $\circ$ cabelo é importante na comunicação social e sexual, sendo símbolo social, cultural e político. A perda de cabelo tem sido associada à perda de atratividade e individualidade. Assim, as reações dos pacientes quanto à alopecia podem variar segundo a importância que dão ao cabelo, grau de perda, preparação e informações recebidas, mecanismos físicos e psicológicos (BATCHELOR, 2001).

Souza e Santo (2008), em estudo com familiares de pessoas que realizam a quimioterapia, mencionam que, a partir dos efeitos colaterais do tratamento e, portanto, da alteração da aparência física do doente, sentimentos como a revolta e a 
vergonha do próprio corpo são referidas, além de frustração, ansiedade, raiva e incertezas por parte dos próprios familiares.

O tratamento quimioterápico pode levar, ainda, devido à queda da imunidade, à necessidade do uso de máscara cirúrgica com o intuito de diminuir as intercorrências por infecção, durante o tratamento. Pelo seu uso ser uma rotina em ambientes públicos, um hábito que não pode ser esquecido ou ignorado, para a própria integridade da criança, apesar de benéfico, pode expor as crianças a uma visão distorcida de pessoas leigas que prejudicam ainda mais a concepção que as crianças têm da própria imagem que adotam, ao utilizarem a máscara, fazendo-as sentir revolta e raiva, além de tristeza por chamarem a atenção das pessoas, uma atenção não desejada. A visão do doente que passa algo para a população é alterada pela compreensão da verdadeira finalidade do uso das máscaras.

"Quando eu ponho máscara, tem umas pessoas que ficam olhando, umas ri, até hoje, eu estava no hospital, uma moça chegou pra mim e falou: 'Você está com esse paninho na boca porque você quebrou os dentes?' Eu falei que não, que era pra não pegar infecção. Aí ela começou a rir e foi embora. Me deu vontade de socar o olho dela." (C. 11 anos)

"Por causa de usar máscara, pra mim tá bom, as pessoas às vezes olham, mas o quê que tem, depois também acostumam, não olham mais, passo e sou uma pessoa normal agora. Me incomodava no começo. A primeira vez me incomodou bastante, só que agora não incomoda mais não. Todo mundo olhava onde eu estava, não queriam chegar perto, achavam que era uma coisa contagiosa, pensavam que eu podia estar passando alguma coisa, mas pra falar a verdade era o contrário, era pra mim não pegar nada. Hoje todo mundo já sabe como é, as pessoas tem mais noção, eles já tem mais experiência do que é isso, do que é aquilo, tem noção do que significa." (J. 18 anos)

"Eu achei pesado o tratamento porque quimioterapia não é fácil, mas é preciso nunca desistir. Eu via pessoas com queda de cabelo, pra mim era deformado. Pra mim, antigamente, via pessoa sem cabelo, de máscara, Nossa Senhora, era um pavor [risos]. Mas hoje é diferente, você acaba conhecendo, vendo que não é aquilo mesmo que você pensava e imaginava. Não é mal hoje em dia, pra quem tem conhecimento, que já passou por isso ou algum caso que teve na família. Tem gente que vê e sai correndo na rua [risos], atravessa a rua. Se você está no ônibus, começam a abrir a janela, acham que vão pegar, mas não é isso, essas pessoas que transmitem pra nós. Eu achava a mesma coisa que eles, ignorante no assunto." (H. 16 anos) 
O uso de máscaras gera constrangimentos à criança e ao adolescente, visto que pessoas que não conhecem sua finalidade a veem como uma proteção para as outras pessoas não entrarem em contato com algum tipo de infecção, gerando curiosidades e discriminação (MOREIRA, 2002).

Muitas vezes é neste momento de realização da quimioterapia e principalmente a partir do aparecimento de seus efeitos colaterais que a criança ou $\circ$ adolescente percebe-se realmente doente, o que é intensificado ao ficar restrito entre os períodos de hospitalização e domićlio, dificultando ainda mais o processo que vivenciam.

"É mesmo forte, aí que eu entrei na realidade que eu tava na doença mesmo, quando começou a cair o cabelo, mas aí eu vi que é pra minha cura, que é preciso." (H. 16 anos)

"Uma experiência muito ruim, muito ruim mesmo. Sofre o tratamento inteiro, é doloroso. Às vezes é física também, mas às vezes, sabe, eu vejo todos os meus amigos saindo, indo zoar e eu sem cabelo. Às vezes eu fico sem cabelo, isso daí me deixa meio triste." (E. 15 anos)

Concordando com o exposto, Françoso (2001) menciona que os efeitos colaterais das drogas fazem com que as crianças percebam-se realmente como doentes, necessitando colocar em prática mecanismos de enfrentamento para viver esta nova situação. Para Woodgate, Degner e Yanofsky (2003), os sintomas trazem para as crianças a sensação do câncer "mais real" em suas vidas e suscita mudanças na rotina familiar, inclusive com perdas e restrições, além de proporcionar dúvidas quanto ao fato de o câncer não estar sendo combatido com deveria.

Os adolescentes veem a quimioterapia como algo que provoca diversas reações no organismo, algo que certamente poderia ser mais ameno e causar menos efeitos indesejáveis que os fazem sofrer. Observamos, ainda, junto aos responsáveis pelas crianças e adolescentes do estudo, o sofrimento dos pais em ver as dificuldades que os filhos vivenciam.

"A quimio não podia fazer esse estrago todo, podia ser só no lugar que ela tem que mexer e pronto, ia ser melhor." (F. 17 anos)

"Uma terapia, hoje eu vejo que é um tratamento pesado. Antigamente eu via só como cabelo, careca e de máscara, uma pessoa que podia transmitir 
alguma coisa, mas hoje é sim um tratamento muito pesado. Forte, os remédios, muito fortes, reagem no corpo." (H. 16 anos)

"A mãe de A., a todo instante, pergunta como o filho se sente, oferece algo para comer, verifica a infusão das drogas, pede informações à equipe e se justifica por impedir visitas ao filho em determinados períodos pósquimioterapia. Menciona que se não tivesse a força de Deus e da família para o que estão vivenciando, certamente não venceriam esta luta. Se emociona e agradece pelas vitórias alcançadas (Observação - Mãe de A.)

Juntamente com o doente, a família vive a experiência do câncer e é submetida, também, a sentimentos angustiantes e dolorosos, vivenciando os mesmos medos, expectativas, dor e sofrimento (BIELEMANN, 2003).

Drury et al. (2005) apontam, em seu estudo, que crianças fisicamente saudáveis, comparadas a crianças que estavam recebendo quimioterapia ou em remissão do câncer, apresentaram índices de maior tamanho físico, força e velocidade. A felicidade e a tristeza também foram avaliadas, sendo apresentados, da mesma forma, menores índices de felicidade dentre crianças que realizavam quimioterapia, comparadas às crianças fisicamente saudáveis.

Concordando com isso, Wiens e Gilbert (2000) reforçam as diferenças entre o estereótipo de crianças com câncer, crianças que recebem tratamento quimioterápico e o de crianças que se encontram em remissão há diversos anos. Mencionam que as crianças saudáveis são fisicamente mais fortes que as crianças que recebem tratamento quimioterápico, no entanto, as crianças que estão em tratamento quimioterápico não se apresentam piores fisicamente que as crianças em remissão.

Em pesquisa realizada no Canadá com pais de crianças com câncer, concluiuse que estes apresentam qualidade de vida mais pobre quando comparados com a população geral. Têm indicadores de qualidade de vida piores, como os relacionados aos hábitos de sono, alimentação e realização de exercícios, indicando estas como possíveis áreas de intervenção (KLASSEN et al., 2008).

Ao mesmo tempo, os efeitos colaterais também podem levar o adolescente a acreditar que a quimioterapia está eliminando o que há de ruim, que o tratamento está tendo um bom desfecho rumo à cura, o que o estimula a continuar.

"Pra fazer e nunca desistir porque tudo o que acontece é pra sua cura. Toda vez que eu vomitava eu pensava que agora estava saindo, queria ficar 
curado, que ia sair todo o mal, foi assim. Os remédios são fortes e por eles serem fortes eles vão me curar, se eu não sentisse nada, como eu ia saber se estava sendo curado, eu ia ficar na dúvida. Hoje eu vejo que da reação eles têm o efeito e eles dando o efeito de eu vomitar eu já sei que está tendo um efeito lá dentro." (H. 16 anos)

Contraditoriamente, apesar do desagrado com a situação, há uma atitude positiva frente à quimioterapia por se acreditar que esta terapêutica pode ser a chance de recuperação da vida (MCCAUGHAN; THOMPSON, 2000).

Contrastando com esta ideia, o adolescente aponta o sofrimento decorrente dos momentos de maior intensidade dos efeitos colaterais da quimioterapia como responsável por também desestimular a continuidade do tratamento.

"Quando eu passo mal dá um negócio, às vezes dá vontade de parar. Aí eu penso melhor, falo: Não, tenho que lutar. Mas se é um fraco mesmo, realmente desanima na hora." (I. 17 anos)

"A primeira noite eu achei que eu não ia viver mais, queria parar o tratamento, só pensei, falei pra minha mãe que eu iria conversar com o médico, que não queria mais fazer nada. Eu imaginava que se fosse toda noite assim, eu não iria aguentar, iria desistir." (H. 16 anos)

As náuseas e vômitos frequentemente limitam o uso dos quimioterápicos e, em alguns pacientes, particularmente adolescentes, podem levar à recusa da continuidade do tratamento (LUISI et al., 2006).

Em um estudo de caso para conhecer a experiência diária de uma adolescente junto aos três primeiros meses de tratamento quimioterápico contra o câncer, Docherty, Sandelowski e Preisser (2006) relataram que a adolescente mencionou que a falta de controle frente aos efeitos adversos do tratamento gerou preocupação, ansiedade e depressão, além de induzir a um questionamento sobre a continuidade do tratamento.

Woodgate, Degner e Yanofsky (2003) referem, ainda, que, ao vivenciar os efeitos do tratamento para o câncer, estes se associam às experiências da doença, promovendo uma reflexão sobre o processo e, pelo baixo controle em amenizá-las, interferem na qualidade de vida das crianças, dos adolescentes e de suas famílias. 
Além dos efeitos colaterais das drogas, os adolescentes mencionam outras intercorrências como as neutropenias, as infecções, as reações alérgicas, sangramentos e extravasamentos decorrentes do tratamento quimioterápico.

Foi ruim porque infecção, a da pele, você passava a mão assim, saía o coro da pele, deu umas feridas, eu dormia só com toalhinha molhada, morna no corpo. A hora que gelava eu começava a chorar, minha mãe ia lá e molhava de novo. A infecção no olho, eu olhava, eu via tudo embaçado, tipo quando tem areia dentro do corpo. Eu peguei uma na perna [infecção] só que já curou, foi do pino, o pino infeccionou." (C. 11 anos)

"Foi da infecção de urina que deu. Eu precisei ficar internada tomando antibiótico, fiquei três dias internada, depois eu fui embora." (G. 15 anos)

"Eu peguei infecção porque estava fraco, peguei fungos." (A. 16 anos)

"Foi a primeira quimio que aconteceu isso, que eu vomitei sangue, eu fiquei muito assustado." (A. 16 anos)

"A única coisa que aconteceu comigo é que eu tive hemorragia no nariz." (F. 17 anos)

"Achei que não ia ter mais jeito, começou a coçar tudo, ficou vermelho, achei que não tinha mais jeito, comecei a descamar. Ela [dermatologista] falou pra eu parar de tomar o remédio porque era efeito do remédio, alérgico. Tirou todos os remédios pra saber qual que era, tirou um monte e mudou a quimioterapia. Aí começou a escamar, cair toda a pele, coçava bastante, tava o corpo inteiro, do pescoço até os pés, caiu tudo, aí voltou pele nova. Pensei que não ia ter jeito porque todo dia que eu acordava, estava até pior." (H. 16 anos)

Segundo Anjos e Zago (2006), a experiência de uma pessoa que faz quimioterapia pode ter como significado a "perda do controle da vida", além de sentimentos ambivalentes de sofrimento e luta para a sua própria sobrevivência.

Segundo Buajordet et al. (2002), em estudo realizado na Norvega para avaliar a frequência e as características dos eventos adversos das drogas utilizadas em crianças, percebeu-se que $28 \%$ destas apresentaram reações adversas às drogas. Dentre as crianças com câncer, tratadas com quimioterápicos, todas apresentaram reações adversas às drogas, sendo $42 \%$ das admissões hospitalares deste grupo relacionadas a eventos adversos de drogas, causados pela quimioterapia. Segundo os autores, de forma geral, os principais eventos adversos foram as desordens do 
SNC, gastrointestinais, de pele, hematológicas, cardiovasculares, hepáticas e outras.

Dos eventos adversos apresentados, 19\% foram considerados graves, sendo, a marioria deles, depressão de medula óssea e complicações causadas pela quimioterapia.

A partir dos relatos, percebemos que as intercorrências foram tratadas, mas geraram medo por estarem intimamente ligadas ao aumento do período de hospitalização.

"Quando dá febre tem que ficar mais três dias porque pegou uma infecção. Quando eu estou na minha casa, se dá febre, minha mãe tem que sair de lá correndo pra vir pra cá $[\mathrm{HC}]$ quando dá $37.8^{\circ} \mathrm{C}$ ! Uma vez nós viemos às duas horas da manhã, deu febre. Nós tivemos que vir correndo. Com a gripe, toma um xarope e já sara na hora. A febre não, toma dipirona, toma medicamento, não resolve nada, tem que colher sangue pra ver o quê que tem, pra ver o quê que é essa febre. Eu penso que eu vou ficar aqui um monte de dias." (C. 11 anos)

"Os dois braços já [extravasamento de quimioterápico]. Teve que aplicar uma injeçãozinha que era pra não formar ferida. Aquilo doeu pra caramba, doeu bastante por causa que era um monte que eles aplicavam, doeu, foi chato porque pode extravasar e começar a formar ferida, a veia estourou e extravasou, já extravasou duas vezes, aqui e aqui no pulso." (A. 16 anos)

\subsubsection{Visão do processo}

Com a confirmação do diagnóstico e identificação da quimioterapia como a terapêutica de escolha para o tratamento, a preocupação com a cura é prontamente assumida pelos familiares e afirmada pelas crianças e adolescentes do estudo. Eles mencionam o percentual de cura, agarrando-se à esperança proporcionada com as altas taxas.

"O doutor chegou e foi me falando: 'Você tem leucemia, mas não se preocupe, tem tratamento, você tem 95\% de chance de ser curado."' (A. 16 anos)

"Ele falou pra minha mãe que era um tumor maligno e minha mãe perguntou se tinha cura. Aí ele falou: 'Tem cura, mas não é destes tumor fraco, é do tumor forte. '"(C. 11 anos) 
Segundo os participantes do estudo, a quimioterapia, apesar de ser lembrada pelos efeitos colaterais indesejáveis e pelas restrições que impõe, também é identificada como a grande esperança de cura, como uma terapêutica de resultado positivo.

"Ela [quimioterapia] é positiva porque vai me curar. Ela vai me curar. Valeu a pena porque eu tô curado. Sempre me fez bem, mesmo com mal-estar, me fez bem, fez o tumor desaparecer." (B. 13 anos)

"Do jeito que os médicos falaram, parece que a quimio era a coisa pior do mundo, mas depois que eu fiz a quimio eu vi que é a coisa mais boa porque matou o meu tumor. Fez a cirurgia, abriu e não tinha mais nada, então fez a quimio e a quimio foi um milagre. Sem a quimio o tumor vai crescer. Ela [quimioterapia] vai direto no tumor e mata o tumor, isso que eu espero, que a quimio faça. E fez porque a hora que abriu a perna, não tinha mais nada. É ruim você ficar aqui internada fazendo quimio, mas você vai ser curado, você vai ter a sua saúde boa aqui, agora se você não for fazer a quimio, você vai estar na sua casa brincando, mas o tumor vai estar lá só crescendo." (C. 11 anos)

"Ajudou nas células pra poder matar as doentes e pra me ajudar a voltar ao normal." (D. 8 anos)

"Todo mundo pensa que é muito sofrimento, que é demais, muito mal. Não sei, eu vou falar que pra mim não é tudo isso, que pra mim foi tranquilo, pra não ficar tão preocupada, tentando fazer uma imagem. Não tem outro jeito de se curar, nenhum é perfeito. Você sempre quer uma coisa, mas acaba alcançando outra então, não tem outro jeito, se tem que destruir as ruins, acaba também destruindo as boas, mas se é pra sarar, se é pra curar, depois volta tudo ao normal, vale a pena com certeza [risos]." (I. 17 anos)

Ao entrevistar adultos que realizam quimioterapia e indagar sobre seus sentimentos, emergiram questões relacionadas à preocupação com os efeitos tóxicos da quimioterapia, a preocupação com a autoimagem, a importância da família no tratamento e a esperança de cura (SALES et al., 2003).

Enquanto a solução da doença não é alcançada, e atividades realizadas no passado ainda não se fazem presentes, cada vitória alcançada é agradecida e referida a todos com grande alegria. Questões até então simples, de pouca importância, ganham amplitude e significado marcante, todas com o propósito de alcançar a almejada cura, a almejada volta à normalidade. Relatam o tratamento quimioterápico como o grande responsável pelas vitórias alcançadas, apresentando 
os resultados positivos percebidos, a partir da diminuição e desaparecimento do tumor.

"Foi fazendo quimio, ele [médico] falou que se não combater com a quimio, vai ter que combater com a radio, mas combateu com a quimio. Eu pensei que quando abrisse [cirurgia no joelho] ainda tinha tumor lá dentro, mas quando abriu não tinha nada. Já venci, só venho aqui fazer visita [risos]. Igual a minha mãe fala: 'Vamos lá passar no hotel cinco estrelas' [risos]. Igual meu pai falou: 'Aquele Natal [2007] filha, nós passamos lá no hospital, que tinha começado o tratamento, agora esse [2008] nós vamos passar na nossa casa e você já vai estar curada.' Eu sou uma guerreira de ter passado por tudo isso que eu passei, por quimio, por febre, por cima de tudo e vou terminar o tratamento e vencer tudo de novo." (C. 11 anos)

"Tem me ajudado porque ele [médico] me falou agora que na minha cabeça ficou só a cicatriz. O passado já era, já foi, sumiu. Agora só o presente. Eu já achei muita coisa, mas agora acabou." (B. 13 anos)

"A quimio matou tudo. No começo eles [médicos] falaram que não ia adiantar fazer quimio porque não ia dar resultado, eles iam marcar a cirurgia pra amputar a minha perna. Pra mim não falaram porque o meu irmão não deixou, falaram que iam tentar fazer uma sessão de quimio, mas se não adiantasse, em dois meses iam ter que marcar a cirurgia pra amputar a minha perna. Eu fiz minha primeira sessão e minha perna desinchou e parou de doer, foi dando resultado a quimio e não foi preciso amputar a perna." (G. 15 anos)

Percebemos que a criança e o adolescente, durante o tratamento e as diferentes fases que se identifica frente à doença, vão tendo suas concepções e pensamentos modificados, vão aprendendo a enxergar a vida e as pessoas, assim como suas vivências, de forma diferente, com um outro olhar.

"Antes eu não ligava muito pra vida, mas aos poucos, as coisas que eu não ligava, agora eu tô dando mais valor na vida." (G. 15 anos)

"Eu acho que a vida inteira da pessoa acaba mudando, você acaba dando mais valor na vida, vendo o mundo de outra maneira, dando mais carinho, amor, compreensão, compreendendo melhor as pessoas para viver uma vida boa, sem muitas brigas que não levam a nada. Eu brigava à toa, reclamava de tudo, agora não. Se alguém pedia alguma coisa, eu falava não. Mas hoje, quando a minha mãe pede alguma coisa, vou na hora, falo nossa, tenho duas pernas pra andar, tem gente no hospital que não tem perna pra fazer as coisas e não pode e eu tenho as duas, tenho saúde." ( $H$. 16 anos) 
"Hoje eu olho pro céu e falo nossa, o céu é bonito hein, olha essa árvore que linda que está hoje. Antes eu nem ligava, nem via céu, não via sol, não via nada, se chovesse, se não chovesse, pra mim estava igual sempre. Agora eu vejo de outra forma, acabo enxergando ao redor, você acaba vendo coisas que você não viu antes, sempre estava perto de você e você não enxergou aquilo ali, coisas mínimas, você acaba dando valor." (H. 16 anos)

"Acho que eu não mudei não. A única coisa que, agora eu tô enxergando mais as coisas, não vendo só as coisas ruins, mas tentando ver as coisas boas pra mim não ficar triste, porque quando a gente fica triste eu acho que o tratamento acaba sendo pior, então eu só tenho que pensar nas coisas boas, de tudo, eu acho que essa é a única coisa que mudou. Eu reclamava demais [risos]. Dá vontade de você ajudar mais as pessoas. Eu nunca imaginei que eu ia ter essa doença, então, do nada foi descobrir, acaba mudando um pouquinho." (I. 17 anos)

Em pesquisa de revisão qualitativa, a fim de evidenciar a experiência de jovens com doenças crônicas, sintetizou-se que os jovens sentem-se incomodados com o seu corpo e com o mundo. Para os jovens, a experiência da doença crônica interrompe a vida "normal", já que veem a doença crônica não desejada gerando restrições à participação dos mesmos junto a atividades antes realizadas, além de trazer incertezas quanto ao presente e ao futuro. No entanto, mencionam que não é uma experiência "tão ruim", pois a doença levou-os a se sentirem melhores, tornando-os mais amáveis e carinhosos. Mencionam, ainda, as recompensas da doença, como aproximação da família (HONS et al., 2008).

Mattsson et al. (2007), objetivando discutir os impactos positivos e negativos do câncer durante a adolescência, a partir de análise de conteúdo, dois anos após o diagnóstico, apontam resultados positivos e negativos. Quanto às consequências negativas, citam os problemas envolvidos com o corpo, como os relacionados a mutilações, resposta deficiente do sistema imune com frequentes resfriados e mudanças na aparência, dificuldades de memória, preocupações com exames e procedimentos, saída do círculo de amigos anteriores à doença, dificuldades com trabalhos escolares e outros. No entanto, a doença proporcionou ainda experiências positivas, como uma visão mais positiva da vida, mudança de valores e apreciação de atividades comuns do dia a dia, boa autoestima, conhecimentos e experiências com relação à doença e cuidados no hospital, habilidade para entender e ajudar 
outras pessoas, apreciar e valorizar a família e amigos, além de amplas perspectivas, resultando em novas atividades de lazer e planos profissionais.

A aceitação e a esperança em um resultado positivo para a doença são grandes armas para o enfrentamento do tratamento. A doença também pode ser encarada pelos adolescentes como mais uma experiência.

"Eu penso que eu vou vencer essa batalha. Pensei que ia correr tudo bem e correu." (C. 11 anos)

"Eu penso que é uma coisa passageira, que não vai durar pra sempre, que eu vou vencer." (H. 16 anos)

"Eu acho que tem que ser calmo, ser paciente pra aguentar tudo isso porque acho que não tem nada de diferente." (A. 16 anos)

"Eu acho importante que as pessoas têm que pensar sempre que, nada vem sem um motivo. Essa doença veio pra mim porque Deus sabia que eu ia aguentar e a gente tem que pensar sempre no lado positivo, nunca ficar pensando, ai meu Deus, por que que eu estou doente, por que que aconteceu isso comigo, sempre tem um motivo e tem que pensar sempre no lado positivo." (I. 17 anos)

"Bom não é, mas é uma experiência também passar por isso. Tudo provém de Deus. Me fez pensar." (G. 15 anos)

Dessa forma, Woodgate, Degner e Yanofsky (2003) apresentam, em seu estudo, a existência de momentos em que os sintomas já são encarados de forma natural para a condição em que vivem, não deixando de serem dolorosos, mas já sendo "normais" e possibilitando o seguimento de suas vidas.

Concluindo, em estudo de De Graves e Aranda (2005), a esperança foi considerada o elemento central que ajuda as famílias a experienciarem o câncer na infância. Profissionais de saúde acreditam que a esperança foi importante no momento do diagnóstico e essencial na ajuda de crianças e famílias com estresse físico e emocional do tratamento. A esperança é, desta forma, importante, mesmo com a progressão da doença.

O desejo da vitória e de uma resolução satisfatória da doença passa a ser o principal e por vezes único objetivo. A partir do presente difícil de hoje, o futuro é almejado e sonhado pelos doentes. Cada passo realizado e vitorioso acende a esperança do futuro promissor, longe das incertezas do hoje. 
"Eu vou estar bem, que essa cicatriz não seja mais o tumor, seja só a cicatriz dele mesmo. Eu tô curado e vou curtir a minha vida, sair com os colegas, ir pra praça." (B. 13 anos)

"Ter bastante fé em Deus. Se vai começar a fazer um tratamento desse, vai dar tudo certo no final." (G. 15 anos)

"Dá bastante medo, mas tento ver o lado positivo, que vai acabar. Está complicando, mas é pro meu bem, é pra eu ficar bem e vai acabar. Só tem que ter força pra aguentar, mas acaba." (I. 17 anos)

O atraso de qualquer prazo esperado pela criança ou adolescente parece uma eternidade. $O$ único desejo é acabar o tratamento, mas no momento percebem que só resta seguir as instruções e aguardar. Os planos se seguem para o término do tratamento, os prazos e as internações previstas são contados e enfatizados, a fim de reforçar a boa resolutividade do caso.

"Pensei que já ia acabar o tratamento, mas não, o doutor falou que ainda tinha mais uns seis meses pra frente." (C. 11 anos)

"Vai ser bem legal voltar a brincar com os meus amigos. Só falta mais duas internações, mas é três anos de tratamento." (D. 8 anos)

"Agora tem mais 10 meses pra fazer, eu fiz quatro sessões antes de fazer a cirurgia, agora eu tenho mais 10 meses, vai dar umas 12 sessões." (G. 15 anos)

As expectativas podem ser diferentes, a entrada no mercado de trabalho ou a volta ao estudo interrompido, mas todos almejam a cura, mesmo cientes de que lá no futuro estarão ainda ligados à doença de hoje, mesmo que de uma maneira mais tênue. Veem no futuro retornos ambulatoriais e acompanhamentos, apenas, sem interferências drásticas no seu cotidiano e de sua família.

"Eu acho que eu vou ter que tomar remédio depois do tratamento, quando eu for curado. Muita gente fala que pra sempre, eu acho que vai ser assim. Eu espero que eu seja curado e venha só pra fazer o retorno, pra ver como que está, se está evoluindo, se nunca mais apareceu, sempre vir fazer acompanhamento e sem tomar remédio [risos]." (H. 16 anos)

"Eu espero que continue tudo assim, continue bem, que eu faça e que dê tudo certo, que acabe logo." (I. 17 anos)

"Tomara que corra tudo bem como correu até agora. Depois que terminar eu vou ver serviço, estudar, começar a estudar de novo." (J. 18 anos) 
"Espero trabalhar, não sei se eu vou trabalhar não, se eu vou entrar numa usina." (B. 13 anos)

O futuro é almejado assim como as atividades antes realizadas no passado o são. Voltar ao que antes se fazia ou vivia é o desejo em questão.

"Eu estou tentando começar de novo a minha vida, fazer o que eu fazia." (A. 16 anos)

"Porque eu não queria estar doente. Queria estar na minha casinha normal, igual era antes. Eu brincava, pulava em cima do sofá, minha avó me xingava e eu só escutando música, o radinho da minha irmã. É ser a criança que eu sempre fui, brincalhona, brincando com os meus amigos." (D. 8 anos)

Assim, Moody et al. (2006) apresentam que, quando incapacitadas de algum movimento, o desejo das crianças foi o de resgatar a capacidade perdida.

Observamos que, para os adolescentes aqui mencionados, o uso do termo normalidade refere-se às atividades rotineiras realizadas no período de ausência de doença e, portanto, normais. Já a anormalidade, para este grupo, está ligada às alterações impostas pela doença, visto que está associada a uma norma diferente da esperada.

"Eu acho que vai valer a pena, eu preciso fazer isso porque eu quero ficar boa, eu tenho que fazer isso pra voltar tudo ao normal, é um pouco complicado, mas vai passar, nem que demore um pouquinho, depois vai voltar tudo ao normal [risos]." (I. 17 anos)

"Acabaram por um certo tempo porque depois eu preciso voltar pra minha vida, vou ter que arrumar outro emprego, começar tudo de novo, começar a guardar dinheiro, tem que pensar lá pra frente de novo. O ano que vem eu vou voltar [se refere a estudar]. Pra tirar carta vai ter que ter o terceiro ano." (J. 18 anos)

Canguilhem (2000) diferencia saúde de doença, porém as coloca como subcategorias de uma categoria mais ampla, a normalidade. Desta forma, saúde e doença fazem parte da normalidade já que se referem a certa norma de vida. Vale ressaltar que doença não é oposto de normal, mas de sadio. A anormalidade é vista, portanto, como uma norma diferente da esperada e não como ausência de normalidade, daí ser associada à doença que comumente gera, mesmo que, temporariamente, normas diferentes das até então desenvolvidas. 


\subsection{REDE DE APOIO}

\subsubsection{União familiar}

Toda a família se reestrutura, principalmente o membro que acompanhará a criança ou o adolescente para o tratamento, seja ambulatorial ou hospitalar. É comum observar o afastamento de pelo menos um dos pais, principais cuidadores, de antigas atividades laborais para uma nova dinâmica familiar que se instala em um momento de diminuição do poder aquisitivo e de aumento do orçamento com custos de viagens, medicamentos, alimentos, dentre outros.

"Eles [irmão e irmã] ficam na minha avó porque meu pai trabalha e minha mãe precisou parar de trabalhar para vir comigo [HC]." (C. 11 anos).

Os membros, a fim de garantir um melhor percurso de tratamento para a criança ou adolescente doente, se unem e recebem o apoio de todos os familiares para o enfrentamento da situação em questão. As próprias crianças e adolescentes percebem uma maior proximidade entre todos, uma maior expressão do amor entre eles advindos, talvez, da preocupação adquirida com o diagnóstico de neoplasia.

"Ficou mais próximo. Acho que eles [familiares] ficaram preocupados. Não é todo dia que eu vejo eles, mas às vezes, de final de semana, eles vão lá em casa me visitar." (F. 17 anos)

"Até aproximou mais a família. Agora todo mundo está indo na igreja, ta ficando mais unida, melhorou bastante a família." (G. 15 anos)

"Eu acho que o amor aumentou [risos]." (H. 16 anos)

"O relacionamento entre os familiares acaba que junta mais, fica mais preocupada." (I. 17 anos)

"Melhorou mais. Nós ficamos mais juntos, mais unidos, a família dela [namorada] deu muita força pra mim, me ajudou bastante e está me ajudando ainda." (J. 18 anos) 
O familiar vivencia junto com o membro doente os sentimentos decorrentes de todo o processo terapêutico e permite que os membros apoiem-se mutuamente, ao garantir sempre o "estar junto", fundamental para o fortalecimento e enfrentamento do processo (SOUZA; SANTO, 2008).

A fim de avaliar a experiência de pais de crianças com câncer e entender como este afeta o seu cuidado, em um estudo realizado na Noruega, os pais referem que apesar das dificuldades, eles se esforçam para ser bons pais. Mencionam, ainda, como aspectos positivos da doença, uma troca de prioridades e uma mudança de valores que aproximam os membros familiares. As necessidades das crianças se tornam o foco, enquanto os pais tentam manter sua vida familiar com o objetivo de protegê-los e tornar o processo seguro e o mais normal possível (HELSETH; ULFSAET, 2005).

Vendo que as crianças estão doentes, os adultos acabam por oferecer o que elas desejam e agradam o máximo possível, a fim de minimizar o sofrimento vivenciado.

"Compra um monte de coisa pra mim, me leva num monte de lugar, leva para pescar. Não estamos indo agora por causa do sol, assim que eu melhorar nós vamos pescar."(B. 13 anos)

"Eu brinco com ela [mãe]. A gente vai caminhar de noite, tomar sorvete, comer lanche. Me dá vontade, minha mãe vai lá e compra sorvete." (B. 13 anos)

\subsubsection{Amigos}

Amigos e parentes oferecem ajuda e tentam estar presentes para a criança ou o adolescente.

"Recebo [visita] da minha família, minhas tias, os vizinhos e as amigas da escola." (C. 11 anos)

"Faço [fisioterapia] na minha cidade. Tem uma amiga que vai na minha casa ajudar, ela vai fazer fisioterapia pra mim." (G. 15 anos) 
A doença pode aproximar as pessoas. $O$ adolescente muitas vezes se apega às pessoas que thes dão atenção, e o fato de poderem contar com estas pessoas, de imaginar e sentir novas amizades garante ânimo para continuar a luta contra a doença e as dificuldades do tratamento.

"É isso, agora eu vou pensar na Bonitona." (B. 13 anos)

"Eu tô com mais amigos. Tem gente, tinha menina que eu nem conhecia, só de longe, mas nunca cheguei a conversar e agora conversa comigo, vai na minha casa, leva as matérias pra mim, brinca comigo, tenho mais amigos agora." (C. 11 anos)

"Fiz [se refere às amizades feitas no hospital] a [menciona os nomes]., muito novas também, aquela que já curou, que a mãe tem uma bebezinha." (D. 8 anos)

"Com os amigos não mudou, eu continei falando, mas só por telefone ou internet, não é a mesma coisa que estar lá junto, todo mundo ficou lá, todo mundo." (I. 17 anos)

As perdas surgem tanto com relação às conquistas anteriores ao tratamento quanto com as alcançadas após o início do seu tratamento. Amizades criadas durante o convívio hospitalar são interrompidas drasticamente, afirmando de forma dolorosa a difícil realidade que vivenciam.

"Os amigos lá do sétimo andar que eu perdi. Quando eu internei, tinha um menino [menciona o nome] que começou a fazer eu entender tudo sobre a quimioterapia, soro, eu não sabia de nada, ele que me ajudava. A [menciona outro nome de amiga], a gente até saía junto porque ela era de Ribeirão. Ela era muito amiga da minha mãe, a gente saía também às vezes [se refere à perda dos amigos como fato que mais o marcou]." (E. 15 anos)

Dunsmore e Quine (1995) mencionam que o suporte de amigos também foi identificado como significante para os adolescentes sobreviventes de câncer que referiram preferência por obter informações sobre a doença, a partir de outro jovem com câncer. 


\subsubsection{Religião}

De forma diferente, a religião se sobressai em toda a família neste momento de indecisões e incertezas. A procura por uma explicação do mal que os atinge ou simplesmente da força para a sua superação mostra-se de forma evidente nos contatos com os doentes e seus familiares, seja nas entrevistas, de forma direta, ou na observação das falas informais durante os diversos contatos.

Por vezes, o adolescente ouve dos adultos a necessidade de buscar nas bases das religiões a causa de sua enfermidade. No entanto, o adolescente a encara de maneira que aceita a situação prontamente, sem explicações, simplesmente porque a ele pertence esta batalha.

"Uma voluntária mesmo falou pra mim que esses que são evangélicos, que não são da igreja católica, eles falam que quando uma pessoa morre e que tem esse problema, ela reencarna em outra pessoa, aí dá esse problema na pessoa. Eu falei pra minha mãe que isso é mentira, que Deus quis isso e foi Ele que colocou essa batalha na minha vida, então é porque eu vou vencer, porque Ele vai ver se eu vou conseguir vencer ela, mas eu vou conseguir."(C. 11 anos)

A religião pode ser encarada como uma base que fortalece a família. Neste momento, a união familiar em busca de Deus pode ajudar os membros e, consequentemente, a criança durante todo o percurso.

"Eu era católica, agora eu sou evangélica. Agora nós estamos mais ligados a Deus, tem gente que ajudou muito o tratamento, ajudou muita coisa." (G. 15 anos)

Há ainda que considerar apenas a aceitação de um Deus, de uma força maior, sem julgamentos quanto às religiões escolhidas. Assim, o adolescente vê a força apenas em Deus e em mais nenhum outro símbolo.

"É Deus, não é quanto à religião, nem católica, evangélica, espírita, testemunha de Jeová, pra mim não tem isso não, isso aqui pra mim é só uma cruz, não tem essa [mostra a cruz que no seu pescoço]. Pra mim, religião é só um detalhe, isso vai da cabeça de cada um." (J. 18 anos) 
O avanço do tratamento da doença e os bons resultados com relação às limitações então impostas são vitórias contadas com detalhes, atribuindo-as, acima de tudo, a Deus.

"Os médicos falaram: 'Mãe, seu filho vai demorar pra falar uns seis meses.' Passou rapidinho, quando eu vi já estava andando, falando. Comecei a mexer os braços, as pernas, comecei a falar com todo mundo, com a minha mãe, comecei a melhorar. Foi na casa da minha tia, a gente tava almoçando, a minha tia tem uma cachorra, aí eu falei o nome dela baixinho. Foi aquela choradeira, minha tia e minha mãe começou a chorar. Chamaram todo mundo, o meu pai, o meu tio, começou todo mundo chorar e eu comecei a falar. Não foram os médicos que me curaram, foi Deus, Ele fez o que Ele quis, estar aqui com você de novo, foi Deus. Eu vim da minha cidade pra cá morto. Fui dormir na casa da minha avó e meu pai começou a chorar: 'Mãe, nós perdemos o B., ele tem um tumor na cabeça' e minha vó falou: 'Meu filho, pra Deus nada é impossível, se Deus quiser ele vai voltar aqui com nós ainda."' (B. 13 anos) 
CONSIDERAÇÕES GERAIS 
Buscamos, diante das crianças e adolescentes com câncer, compreender como vivenciam a experiência da quimioterapia a fim de, a partir das demandas e dos sentimentos observados, poder incorporar as necessidades emergentes em um plano de cuidados de enfermagem direcionado à qualidade de vida das crianças, adolescentes e, consequentemente, familiares.

O trabalho com as crianças e adolescentes foi complexo, primeiro pela aproximação e vínculos necessários para um levantamento íntimo e pessoal frente aos sujeitos desta pesquisa. Depois, por entender os sentimentos levantados por eles e perceber o real sofrimento que todo o processo de doença e a busca pela cura causam na família em geral.

Assim, para as crianças e adolescentes deste estudo, a experiência da quimioterapia vem intimamente ligada à experiência da doença em si, do câncer, sendo impossível entender a dimensão da terapêutica, sem antes compreender a base desta questão, o câncer infanto-juvenil.

As crianças e os adolescentes relataram toda a trajetória até o diagnóstico, mencionando os sinais e sintomas apresentados, as dúvidas, exames e procedimentos envolvidos, a busca por diversos profissionais, a dificuldade para a elucidação do diagnóstico, a aceitação ou recusa do mesmo e ainda a triste confirmação de uma recidiva, seguida de sentimentos diante do estado de ver-se novamente com câncer.

A doença passa, então, a ser conhecida e definida pelos sujeitos da pesquisa, definição resumida quanto às questões técnicas e comumente com conceitos limitados ou errôneos. Os maiores destaques foram quanto às questões observáveis fisicamente, como o tamanho do tumor e a sua localização.

As dúvidas, neste momento, levam o adolescente a pesquisar sobre sua doença em meios no qual tem acesso, principalmente a internet. Desta forma, diversas descrições obtidas por esta fonte são comparadas com o quadro que apresentam. Informações generalizadas encontradas nos sites, muitas vezes sem nenhum critério científico, deixam o adolescente repleto de angústia e medo por imaginar a alta letalidade da doença, visão que é gradualmente modificada, a partir de conversas com os profissionais de saúde, observação de outros quadros nas enfermarias e a própria progressão do tratamento diante de cada vitória alcançada. 
Percebemos, no decorrer do processo, a alteração de humor que ocorre por diversos motivos, seja pela internação prolongada, seja por revolta ou não aceitação da situação, seja pelo desejo de simplesmente voltar a ser tudo como antes. Afinal, hábitos são modificados, restrições são impostas, isolamento de parentes e amigos se torna presente, uma quebra inesperada da rotina familiar é vislumbrada, e todo o dia a dia é modificado. Até mesmo a escola, rotineira, passa a ser apenas visitada, esporadicamente, dependendo da fase do tratamento e das condições do doente, o que ainda gera mais uma preocupação, a de continuidade dos estudos com qualidade. Destacados pelos sujeitos do estudo, estes são pontos extremamente importantes para a visão final de todo o processo.

A quimioterapia, critério de inclusão das crianças e adolescentes para este estudo, trouxe, para os mesmos, diferentes visões no decorrer dos ciclos. Lembrada, principalmente por seus efeitos colaterais e o sofrimento decorrente, causa, de imediato, um forte impacto e deixa sobressair o medo. A necessidade de iniciar a terapêutica, muitas vezes, não permite um tempo de adaptação anterior à sua realização, o que reforça as dificuldades, visto que ligada à quimioterapia temos a hospitalização e as restrições, mudanças que alteram todo o dia a dia da criança, do adolescente e de sua família.

Com o início das infusões quimioterápicas, começam a entender melhor o processo, questionar e observar, o que permite que definam a terapêutica. Da mesma forma que ocorre com a doença, a quimioterapia é definida resumidamente, prevalecendo conceitos quanto à função principal e a sua importância para a almejada cura.

Além das preocupações quanto aos mais frequentes efeitos colaterais como náuseas, vômitos, mal-estar, indisposição, falta de apetite, perda de peso, cefaleia, alopecia e irritações na pele, as crianças e os adolescentes destacam o medo de procedimentos invasivos como as punções venosas, pois, apesar de perceberem que a quimioterapia não dói, ela exige a utilização de dispositivos prévios que causam dor, pavor e medo, inclusive da morte, quando realizados procedimentos muito dolorosos. Aliado a estas preocupações, estão incluídas as intercorrências como os extravasamentos de drogas, as neutropenias, infecções e outras que mudam todo o planejamento e exigem, muitas vezes, um maior tempo de hospitalização. 
O carinho e a atenção dos profissionais para com as crianças e os adolescentes são, neste momento, fundamentais para garantir uma minimização do trauma causado pelos procedimentos e por toda a experiência vivenciada, pois garantem, principalmente, maior tranquilidade e confiança na terapêutica, o que favorece o sucesso nas condutas.

A imagem corporal é outro ponto de impacto nas crianças e adolescentes, principalmente a alopecia, a perda de peso, o medo da mutilação e o uso de máscaras que terminam por destacar, visualmente, para as outras pessoas, que há algo diferente do habitual. A fim de amenizar algumas mudanças, meninos e meninas utilizam, quando possível, estratégias para omitir ao menos a alopecia, como bonés, chapéus e lenços.

Passado o primeiro impacto das alterações físicas, com o decorrer do tratamento, as preocupações principais saem das dimensões físicas e atingem um patamar direcionado à evolução e recuperação da doença, uma preocupação apenas ligada ao prognóstico do quadro que vivenciam.

Observada em todos os momentos, a quimioterapia é identificada e diferenciada quanto a aspectos físicos e mesmo sensações provocadas pela infusão. As crianças e os adolescentes mencionam ainda as diversas vias utilizadas e a diferença de intensidade dos efeitos sentidos, diante dos diferentes ciclos propostos.

Os efeitos colaterais são vistos ora como responsáveis por demonstrar o sucesso da terapêutica sobre a doença e então estimular a continuidade do tratamento, ora por desestimular, visto o intenso sofrimento que provocam.

Os períodos de infusão de drogas quimioterápicas e os primeiros dias que se seguem são de marcante indisposição. Mencionam, desta forma, o forte desejo por repouso, permitindo observar a fadiga resultante da experiência que vivenciam, seja da doença, da quimioterapia ou da hospitalização.

Para o jovem, a doença crônica interrompe uma vida até então normal e provoca dúvidas quanto ao futuro e mesmo o presente. Em contrapartida, com o tempo, mencionam encarar a doença, sentida pelos efeitos da quimioterapia, como algo que os fizeram enxergar o mundo de outra maneira, pois sentiram uma verdadeira mudança de jeito de ser, ao adquirir uma visão de mundo antes vista sem 
maiores detalhes, sem cor ou comprometimento, para um mundo que é observado em todas as suas nuances, um mundo de que querem fazer parte.

A doença, por fim, é vista como algo a ser vencido e, graças à quimioterapia, é passível de tal desfecho, o que certamente será responsável por garantir força para vencer as futuras intercorrências da vida.

Para o jovem, a família é vista de forma mais unida e com laços mais fortes, além de um marco de apoio e de força para a luta que vivenciam, mostrando intensificada a dependência que têm dos cuidadores que, por sua vez, esforçam-se para protegê-los.

Brincar, ter a família e os amigos por perto, buscar Deus, conhecer a doença e enfrentá-la, se envolver em todo o processo, ter esperança de vitória, relembrar, no presente, cada momento do passado anterior à doença e transpor para o futuro o que chamam de normalidade, são as grandes estratégias utilizadas para o sucesso de uma terapêutica difícil, sofrida, dolorosa, restritiva, mas acima de tudo, responsável pela sua cura, por mais uma vitória na corrida da vida. 
REFERÊNCIAS 
ALCOSER, P. W.; RODGERS, C. Treatment strategies in childhood cancer. Journal of Pediatric Nursing, v. 18, n. 2, p. 103-112, 2003.

ALDISS, S. et al. What is important to young children who have cancer while in hospital? Children et Society, 2008. 14p.

ALMEIDA, F. A. Lidando com a morte e o luto por meio do brincar: a criança com câncer no hospital. Boletim de Psicologia, v. LV, n. 123, p. 149-167, 2005.

ANELLI, A.; ANELLI, T. F. M. Fundamentos em quimoterapia antineoplásica. In: AYOUB, A. C. et al. Bases da enfermagem em quimioterapia. São Paulo: Lemar, 2000. Cap. 3.

ANJOS, A. C. Y.; ZAGO, M. M. F. A experiência da terapêutica quimioterápica oncológica na visão do paciente. Revista Latino-Americana de Enfermagem, v. 14, n. 1, p. 33-40, 2006.

BARDIN, L. Análise de conteúdo. 3. ed. Lisboa: Edições 70, 2004. 223p.

BASHORE, L. Childhood and adolescent cancer survivors knowledge of their disease and effects of treatment. Journal of Pediatric Oncology Nursing, v. 21, n. 2, p. 98$102,2004$.

BATCHELOR, D. Hair and cancer chemotherapy: consequences and nursing care - a literature study. European Journal of Cancer Care, v. 10, p. 147-163, 2001.

BESSEL, A. G. Children surviving cancer: psychosocial adjustment, quality of life, and school experiences. Except Child (the Council for Exceptional Children), v. 67, p. 345$359,2001$.

BIASOLI-ALVES, Z. M. M. A pesquisa em psicologia - análise de métodos e estratégias na construção de um conhecimento que se pretende científico. In: Romanelli, G.; Biasoli-Alves, Z. M. M. (org). Diálogos metodológicos sobre a prática de pesquisa. Ribeirão Preto: Legis Summa, p.135-57, 1998.

\footnotetext{
${ }^{2}$ Referências normatizadas de acordo com a Associação Brasileira de Normas Técnicas.
} 
BIELEMANN, V. L. M. A família cuidando do ser humano com câncer e sentindo a experiência. Revista Brasileira de Enfermagem, v. 56, n. 2, p. 133-137, 2003.

BLARISON, D. They never want to tell you: children talk about cancer. Cambridge (ENG): Harvard University Press, 1991.

BOGDAN, R.; BIKLEN, S. Investigação qualitativa em educação: uma introdução à teoria e aos métodos. Tradução Maria João Alvarez, Sara Bahia dos Santos e Telmo Mourinho Baptista. 2a ed. Porto (Portugal): Porto Editora, 1994. 336 p.

BONASSA, E. M. A. Enfermagem em terapêutica oncológica. 3. ed. São Paulo: Atheneu, 2005.

BRASIL. Ministério da Educação e Cultura (MEC). Secretaria Nacional de Educação Especial. Política nacional de educação especial. Brasília, 1994. 49p.

BRASIL. Ministério da Saúde. Conselho Nacional de Saúde. Comissão Nacional de Ética em Pesquisa. Resolução n. 196/96. Diretrizes e normas reguladoras de pesquisa envolvendo seres humanos. Brasília (DF): Ministério da Saúde, 1996.

BRASIL. Ministério da Saúde. Instituto Nacional de Câncer. Câncer. 2008a. Disponível em: <http://www.inca.gov.br/conteudo_view.asp?ID=322>. Acesso em: 10 abril 2008.

BRASIL. Ministério da Saúde. Instituto Nacional de Câncer. Epidemiologia dos tumores da criança e do adolescente. 2008b. Disponível em: <hHp://www.inca. gov.br/conteudo_view.asp?id=349>. Acesso em: 10 abril 2008.

BRASIL. Ministério da Saúde. Instituto Nacional de Câncer. Estimativa 2008: Incidência de câncer no Brasil. Rio de Janeiro, 2007, 94p. Disponível em: <http:// www.inca.gov.br/estimativa/2008/versaofinal.pdf>. Acesso em: 10 abril 2008.

BRASIL. Ministério da Saúde. Instituto Nacional de Câncer. Particularidades do câncer infantil. 2008c. Disponível em: <http://www.inca.gov.br/conteudo_view.asp?id= 343>. Acesso em: 10 abril 2008. 
BRASIL. Ministério da Saúde. Instituto Nacional de Câncer. Quimioterapia. 2008d. Disponível em: <http://www.inca.gov.br/conteudo_view.asp? ID =101>. Acesso em 06 maio 2008.

BRASIL. Ministério da Saúde. Instituto Nacional de Câncer. Incidência do câncer infantil. 2008e. Disponível em: <http://www.inca.gov.br/releases/press_release_ view.asp? ID =1974>. Acesso em: 24 junho 2009.

BUAJORDET, I. et al. Adverse drug events in children during hospitalization and after discharge in a Norwegian University Hospital. Acta Paediatric, Stockholm, v. 91, p. 88-94, 2002.

BUIZER, A. I. et al. Behavioral and educational limitations after chemotherapy for childhood acute lymphoblastic leukemia or wilms tumor. Cancer, v. 106, n. 9, p. 2067-2075, 2006.

CAMARGO, B.; LOPES, L. F. Pediatria oncológica: noções fundamentais para o pediatra. São Paulo: Lemar, 2000.

CANGUILHEM, G. O normal e o patológico. 5. ed. Rio de Janeiro: Florense Universitária, 2000.

CARVALHO, M. M. Psico-oncologia: história, características e desafios. Psicologia USP, São Paulo, v. 13, n. 1, p. 1-14, 2002.

CAVICCHIOLI, A. C.; MENOSSI, M. J.; LIMA, R. A. G. Câncer infantil: o itinerário diagnóstico. Revista Latino-Americana, v. 15, n. 5, 2007.

CLOSE, P. et al. A prospective, controlled evaluation of home chemotherapy for children with câncer. Pediatrics, v. 95, p. 896-900, 1995.

COSTA, C. L. Avaliação de aspectos psicossociais da população de pacientes fora de tratamento de câncer infantil: qualidade de vida, morbidade psiquiátrica, presença de comportamento de risco e adequação social. 2005. 156 f. Tese (Doutorado). Fundação Antônio Prudente, São Paulo, 2005. 
COSTA, J. C.; LIMA, R. A. G. Crianças / adolescentes em quimioterapia ambulatorial: implicações para a enfermagem. Revista Latino-Americana de Enfermagem, v. 10, n. 3, p. $321-333,2002$.

DE CHICO, E.; HAYASHI, V. D.; FERREIRA, N. M. L. A. Ações educativas de enfermagem para o cuidado domiciliário do doente fora de possibilidade de cura. Trabalho de Conclusão de Curso, Universidade Federal de São Carlos, São Carlos, 2004.

DE CHICO, E.; HAYASHI, V. D.; FERREIRA, N. M. L. A. Vivenciando uma experiência dolorosa: a representação social do doente oncológico. Trabalho de Iniciação Científica, Universidade Federal de São Carlos, São Carlos, 2003.

DECKER, C. L. Social support and adolescent cancer survivors: a review of the literature. Psycho-Oncology, v. 16, p. 1-11, 2007.

DE GRAVES, S.; ARANDA, S. When a child cannot be cured - reflections of health professionals. European Journal of Cancer Care, v. 14, p. 132-140, 2005.

DOCHERTY, S. L.; SANDELOWSKI, M.; PREISSER, J. S. Three months in the symptom life of a teenage girl undergoing treatment for cancer. Nursing \& Health, v. 29, p. 294-310, 2006.

DOROSHOW, J.H. Princípios da oncologia médica. In: POLLOCK, R.E. et al. (ed). Manaul de Oncologia Clínica da UICC. 8. ed. São Paulo: Fundação Oncocentro de São Paulo, 2006. Cap. 10 C.

DRURY, A. M. et al. Adults' attitudes toward children with cancer. Journal of Psychosocial Oncology, v. 23, n. 1, p. 41-54, 2005.

DUARTE, R. Entrevistas em pesquisas qualitativas. Curitiba: Educar, n. 24, p. 213-25, 2004.

DUNSMORE, J.; QUINE, S. Information, support, and decision-making needs and preferences of adolescents with cancer: implication for health professionals. Journal of Psychosocial Oncology, v. 13, n. 4, p. 39-55, 1995. 
EDDY, L.; CRUZ, M. The relationship between fatigue and quality of life in children with chronic health problems: a systematic review. Journal for Specialist in Pediatric Nursing, v. 12, n. 2, 2007.

FAUX, A. S.; WALSH, M.; DEATRICK, J. A. Intensive interviewing with children and adolescent. West Journal Nursing Researchs, v. 10, n. 2, p. 180-194, 1988.

FERREIRA, N. M. L.; DE CHICO, E.; HAYASHI, V. D. Buscando compreender a experiência do doente com câncer. Revista de Ciências Médicas. Campinas, v. 14, n. 3, p. 239-248, 2005.

FRANÇOSO, L. P. C. Vivências de crianças com câncer no grupo de apoio psicológico: estudo fenomenológico. 2001. 208 f. Tese (Doutorado). Faculdade de Filosofia, Ciências e Letras de Ribeirão Preto, Universidade de São Paulo, Ribeirão Preto, 2001.

FUNDAÇÃO ONCOCENTRO DE SÃO PAULO (FOSP). Tumores da infância. In: Aspectos epidemiológicos do câncer no estado de São Paulo. 2002. CD-ROM. Disponível em: <http://www.fosp.saude.sp.gov.br/html/at_tumores_infancia.html>. Acesso em: 1 agosto 2007.

GOMES, R. Análise e interpretação de dados de pesquisa qualitativa. In: MINAYO, M. C. S. (org) Pesquisa social: teoria, método e criatividade. Petrópolis: Vozes, 2007.

HAAGEDOORN, E. M. L. et al. Oncologia básica para profissionais de saúde. São Paulo: Associação Paulista de Medicina, 2000.

HAYASHI, V. D.; DE CHICO, E.; FERREIRA, N. M. L. A. Aplicação do modelo Calgary de enfermagem e família: um enfoque em oncologia. Trabalho de Iniciação Científica, Universidade Federal de São Carlos, São Carlos, 2004.

HELSETH, S.; ULFSAET, N. Parenting experiences during cancer. Journal of Advanced Nursing, v. 52, n. 1, p. 38-46, 2005.

HOCKENBERRY, M. Symptom management research in children with cancer. Journal of Pediatric Oncology Nursing, v. 21, n. 3, p. 132-136, 2004. 
HOCKENBERRY-EATON, M. et al. Developing a conceptual model for fatigue in children. European Journal of Oncological Nursing, v. 3, n. 1, p. 5-11, 1999.

HOCKENBERRY-EATON, M. et al. Fatigue in children and adolescents with cancer. Journal of Pediatric Oncology Nursing, v. 15, n. 3, p. 172-182, 1998.

HONS, A. V. B. A. et al. Understanding young peoples' experience of chronic illness: a systematic review. International Journal of Evidence Based Healthcare, v. 6, p. 321 $336,2008$.

JEMAL, A. et al. Cancer statistics, 2006. CA: A Cancer Journal for Clinicians, v. 56, n. 2, p.106-130, 2006.

JUN LI, T. D. et al. Cancer incidence among children and adolescents in the United States, 2001-2003. Pediatrics, v. 121, n. 6, p. 1470-77, 2008.

KLASSEN, A. F. et al. Impact of caring for a child with cancer on parents' healthrelated quality of life. Journal of Clinical Oncology, v. 26, n. 36, p. 5884-5889, 2008.

KOREN, G.; SCHECHTER, T. Cancer chemotherapy in young children: challenges and solutions. Pediatric Blood Cancer, v. 49, p. 1091-1092, 2007.

KRUEGER, G. The formation of the American Society of Clinical Oncology and the development ofa medical specialty, 1964-1973. Perspectives in Biology and Medicine, v. 47 , n. 4, p. 537-552, 2004.

LANGEVELD, N. E. et al. Quality of life in young adult survivors of childhood cancer. Supportive Care in Cancer, Berlim, v. 10, n. 8, p. 579-600, 2002.

LEMOS, F. A.; LIMA, R. A. G.; MELLO, D. F. Assistência à criança e ao adolescente com câncer: a fase de quimioterapia intratecal. Revista Latino-Americana de Enfermagem, v. 12, n. 3, p. 485-493, 2004.

LESAGE, P.; PORTENOY, R. K. Management of fatigue in the cancer patient. Oncology, v. 16, n. 3, p. 373-389, 2002. 
LIANG, H-F. et al. A comparison of emotional / behavioural problems between Taiwanese children with cancer and healthy controls. Journal of Clinical Nursing, v. 17, p. 304-311, 2008.

LINET, M. S. et al. Cancer surveillance series: recent trends in childhood cancer incidence and mortality in the United State. Journal of the National Cancer Institute, v. 91, n. 12, p. 1051-1058, 1999.

LOPES, L. F.; CAMARGO, B.; BIANCHI, A. Os efeitos tardios do tratamento do câncer infantil. Revista Associação Médica Brasil, v. 46, n. 3, p. 277-284, 2000.

LOURENÇO, M. T. C.; COSTA, C. L. Aspectos psicológicos do doente em quimioterapia. In: AYOUB, A. C. et al. Bases da enfermagem em quimioterapia. São Paulo: Lemar, 2000. Cap. 33, p. 489-495.

LUISI, F. A. V. et al. Contribution to the treatment of nausea and emesis induced by chemotherapy in children and adolescents with osteosarcoma. São Paulo Medical Journal, v. 124, n. 2, p. 61-65, 2006.

MASTELLARO, M. J. et al. Clínica de atendimento após o término da terapia (CATT): compromisso com o futuro. Revista Âmbito Hospitalar, São Paulo, n. 169, p. 30-32, 2004.

MATTSSON, E. et al. Positive and negative consequences with regard to cancer during adolescence: experiences two years after diagnosis. Psycho-Oncology, v. 16, p. 10031009, 2007.

MAUNSELL, E. et al. Quality of life among long-term adolescent and adult survivors of childhood cancer. Journal of Clinical Oncology, v. 24, n. 16, p. 2527-2535, 2006.

MCCAFFREY, C. N. Major stressors and their effects on the well-being of children with cancer. Journal of Pediatric Nursing, v. 21, n. 1, p. 59-66, 2006.

MCCAUGHAN, E. M.; THOMPSON, K. A. Information needs of cancer patients receiving chemotherapy at a day-case unit in Northern Ireland. Journal of Clinical Nursing, v. 9, p. 851-858, 2000. 
MINAYO, M. C. S. (Org.). Pesquisa social: teoria, método e criatividade. 25. ed. Petrópolis: Vozes, 2007. 108 p.

MIRRA, A. P.; LATORRE, M. R. D. O.; VENEZIANO, D. B. (ed). Ministério da Saúde. Incidência, mortalidade e sobrevida do câncer da infância no município de São Paulo. São Paulo, Registro de Câncer de São Paulo, 2004. 60 p.

MITCHELL, T. The social and emotional toll of chemotherapy - patients' perspectives. European Journal of Cancer Care, v. 16, p. 39-47, 2007.

MOODY, K. et al. Exploring concerns of children with cancer. Support Care Cancer, v. 14, p. 960-966, 2006.

MOORE, I. M. et al. Behavioral adjustment of children and adolescents with cancer: teacher, parent, and self-report. Oncology Nursing Forum, v. 30, n. 5, p. 84-91, 2003.

MOREIRA, G. M. S. A criança com câncer vivenciando a reinserção escolar: estratégia de atuação do psicólogo. 2002. 137 f. Dissertação (Mestrado). Faculdade de Filosofia, Ciências e Letras de Ribeirão Preto, Universidade de São Paulo, Ribeirão Preto, 2002.

MOREIRA, H.; CALEFFE, L. G. Abordagens à pesquisa. In: Metodologia da pesquisa para o professor universitário. Rio de Janeiro: DP\&A, 2006. Cap. 2.

MORSE, J. M.; RICHARD, S. L. Read me first for a user's guides to qualitative methods. Thousand Oaks: Sage Publications, 2002.

NASCIMENTO, L. C. et al. Crianças com câncer e suas famílias. Revista da Escola de Enfermagem da Universidade de São Paulo, v. 39, n. 4, p. 469-474, 2005.

NATIONAL CANCER INSTITUTE. A snapshot of pediatric cancers. Disponível em: $<$ http://planning.cancer.gov/disease/Pediatric-Snapshot.pdf>. Acesso em: 10 abril 2008. 
OLIVEIRA, B. M. et al. Avaliação da adesão ao tratamento através de questionários: estudo prospectivo de 73 crianças portadoras de leucemia linfoblástica aguda. Jornal de Pediatria. Rio de Janeiro, v. 84, p. 245-50, 2005.

PASTORE, G. et al. Childhood soft tissue sarcomas incidence and survival in European children (1978-1997): report from the Automated childhood cancer information system project. European Journal of Cancer, v. 42, n. 13, p. 2136-2149, 2006.

PEDRO, I. C. S. et al. O brincar em sala de espera de um ambulatório infantil na perspectiva de crianças e seus acompanhantes. Revista Latino-Americana de Enfermagem, v. 15, n. 2, 2007.

PERDIKARIS, P. et al. Changes in children's fatigue during the course of treatment for paediatric cancer. International Nursing Review, v. 55, p. 412-419, 2008.

PEREIRA, W. P. Leucemia Mielocítica Aguda da infância e adolescência - fracassos e vitórias. Revista Brasileira de hematologia e hemoterapia, v. 28, n. 4, p. 239-245, 2006.

POLIT, D. F.; BECK, C. T. Nursing Research: principles and methods. 7. ed. Philadelphia: Lippincott Williams \& Wilkins, 2004. Cap. 2.

POLIT, D. F; HUNGLER, B. P. Fundamentos da pesquisa em enfermagem. Tradução Regina Machado Garcez. 3. ed. Porto Alegre: Artes Médicas, 1995.

PORTENOY, R. K. Cancer related fatigue: an immense problem. Oncologist, v. 5, p. 350-352, 2000.

RICHARDSON, R. C.; NELSON. M. B; MEESKE, K. Young adult survivors of childhood cancer: attending to emerging medical and psychosocial needs. Journal Pediatric Oncology Nursing, Philadelphia, v. 16, n. 3, p. 136-144, 1999.

ROBINSON, D. L.; CARR, B. A. Delayed vomiting in children with cancer after receiving moderately high or highly emetogenic chemotherapy. Journal of Pediatric Oncology Nursing, v. 24, n. 2, p. 70-80, 2007. 
RODRIGUES, K. E.; CAMARGO, B. Diagnóstico precoce do câncer infantil: responsabilidade de todos. Revista Associação Médica Brasileira, v. 49, n. 1, p. 29 34, 2003.

SAEGROV, S.; HALDING, A. G. What is it like living with the diagnosis of cancer? European Journal of Cancer Care, v. 13, p. 145-153, 2004.

SALES, C. A. et al. A existencialidade da pessoa com neoplasia em tratamento quimioterápico. Acta Scientiarum. Health Sciences, v. 25, n. 2, p. 177-182, 2003.

SANTACROCE, S. Uncertainty, anxiety, and symptoms of posttraumatic stress in parents of children recently diagnosed with cancer. Journal of Pediatric Oncology Nursing, v. 19, n. 3, p. 104-111, 2002.

SCHNEIDER, S. M.; HOOD, L. E. Virtual reality: a distraction intervention for chemotherapy. Oncology Nursing Forum, v. 34, n. 1, p. 39-46, 2007.

SCHULTZ, K. A. P. et al. Behavioral and social outcomes in adolescent survivors of childhood cancer: a report from the childhood cancer survivor study. Journal of Clinical Oncology, v. 25, n. 24, p. 3649-3656, 2007.

SEITZ, D. C. M. et al. Psychosocial interventions for adolescent cancer patients: a systematic review of the literature. Psycho-Oncology, 2008. 8p.

SHAW, S. R.; MCCABE, P. C. Hospital-to-school transition for children with chronic illness: meeting the new challenges of an evolving health care system. Psychology in the Schools, v. 45, n. 1, p. 74-87, 2008.

SILVA, M. J.; ALMEIDA, L. A. Quimioterapia. In: BARACAT, F. F.; FERNANDEZ JR, H. J.; SILVA, M. J. Cancerologia atual - um enfoque multidisciplinar. São Paulo: Roca, 2000. Cap. 5.

SKOLIN, I. et al. Altered food intake and taste perception in children with cancer after start of chemotherapy: perspective of children, parents and nurses. Support Care Cancer, v. 14, p. 369-378, 2006. 
SOUZA, M. G. G.; SANTO, F. H. E. O olhar que olha o outro... um estudo com familiares de pessoas em quimioterapia antineoplásica. Revista Brasileira de Cancerologia, v. 54, n. 1, p. 31-41, 2008.

STASI, et al. Cancer related fatigue: evolving concepts in evaluation and treatment. Cancer, v. 98, n. 9, p. 1786-1801, 2003.

STEUBER, C. P.; NESBIT JR, M. E. Clinical assessment and differential diagnosis of the child suspected cancer. In: PIZZO, P. A.; POPLACK, D. G. (ed). Principles and practice of pediatric oncology. 3. ed. Philadelphia: Lippincont-Raven, p. 129-139, 1997.

STEVENS, B. et al. Home chemotherapy for children with cancer: perspectives from health care professionals. Health and Social Care in the Community, v. 12, n. 2, p. 142-149, 2004.

TEIXEIRA, R. A. P. et al. Câncer infantil. In: BARACAT, F. F.; FERNANDEZ JR, H. J.; SILVA, M. J. Cancerologia atual - um enfoque multidisciplinar. São Paulo: Roca, 2000. Cap. 28.

THOMPSON, S. When kids get cancer. RN Magazine, v. 66, n. 7, p. 29-33, 2003.

TURATO, E. R. Métodos qualitativos e quantitativos na área da saúde: definições, diferenças e seus objetos de pesquisa. Revista de Saúde Pública, v. 39, n. 3, p. 507$514,2005$.

VALLE, E. R. M. 1997. Câncer infantil: compreender e agir. Campinas: Psy, 1997.

VALLE, E. R. M. Grupo de apoio aos pais de crianças com câncer. Disponível em: <http://www.oncoguia.com.br/suportes/13_gruposapoiopais.asp>. Acesso em: 23 março 2006.

VALLE, E. R. M.; FRANÇOSO, L. P. C. Quimioterapia em crianças. Clínica Pediátrica, v. 16, n. 4, p. $40-52,1992$.

VANCE, Y. H.; EISER, C. The school experience of the child with cancer. Child: Care, Health \& Development, v. 28, n. 1, p. 5-19, 2002. 
VAN DER MOLEN, B. Relating information needs to the cancer experience. European Journal of Cancer Care, v. 9, p. 41-47, 2000.

VENTAFRIDDA, V. et. al. Atendimento de apoio e avaliação da qualidade de vida. In: POLLOCK, R. E. et al. (ed). Manual de Oncologia Clínica da União Internacional Contra o Câncer. São Paulo: Fundação Oncocentro de São Paulo, 2006.

VIEIRA, M. A.; LIMA, R. A. G. Crianças e adolescentes com doença crônica: convivendo com mudanças. Revista Latino-Americana de Enfermagem, v. 10, n. 4, p. 552-560, 2002.

WIENS, B. A.; GILBERT, B. O. A reexamination of childhood cancer stereotype. Journal of Pediatric Psychology, v. 25, p. 151-159, 2000.

WINT, S. S. et al. Effects of distraction using Virtual Reality Glasses during lumbar punctures in adolescents with cancer. Online Exclusive, v. 29, n. 1, p. 8-15, 2002.

WOODGATE, R. L.; DEGNER, L. F. Cancer symptom transition periods of children and families. Journal of Advanced Nursing, v. 46, n. 4, p. 358-368, 2004.

WOODGATE, R. L.; DEGNER, L. F.; YANOFSKY, R. A different perspective to approaching cancer symptoms in children. Journal of Pain and Symptom Management, v. 26, n. 3, p. 800-817, 2003.

WRIGHT, E. P. et al. Social problems in oncology. British Journal of Cancer, v. 87, p. 1099-1104, 2002.

YEH, C. H. et al. Clinical factors associated with fatigue over time in pediatric oncology patients receiving chemotherapy. British Journal of Cancer, v. 99, p. 23-29, 2008.

YEH, C. H. Health related quality of life in pediatric patients with cancer. A structural equation approach with the Roy Adaptation Model. Cancer Nursing, v. 25, n. 1, p. 74-80, 2002. 


\section{APÊNDICES}


Título da pesquisa: Crianças e adolescentes com câncer: experiências com a quimioterapia

Meu nome é Elizelaine de Chico Cicogna, sou enfermeira (COREN-SP no 0118264 ) e aluna do Programa de Pós-Graduação Enfermagem em Saúde Pública da Escola de Enfermagem de Ribeirão Preto da Universidade de São Paulo e gostaria de convidá-lo(a) a participar de uma pesquisa que será realizada aqui no Hospital das Clínicas. A minha orientadora é a Profa. Regina Aparecida Garcia de Lima, enfermeira (COREN-SP no 13469) e professora do Departamento de Enfermagem Materno-Infantil e Saúde Pública da Escola de Enfermagem de Ribeirão Preto da Universidade de São Paulo. O objetivo deste trabalho é conhecer sua experiência com a quimioterapia. Para isso faremos algumas perguntas para poder conhecer um pouco a sua história. Precisaremos nos encontrar algumas vezes aqui na Sala de Quimioterapia ou na enfermaria; nossas conversas serão mantidas em segredo e serão utilizadas somente para esta pesquisa. Seu nome verdadeiro não irá aparecer e se você não quiser responder algumas questões poderá não respondê-las. Se você concordar, nossas conversas serão gravadas, para que eu não esqueça nada do que foi dito e depois passadas para o papel, sendo que você poderá ler, se quiser.

Gostaríamos, também, de ter autorização para consultar seu prontuário para conhecermos como tem sido o seu tratamento.

Quando terminarmos este trabalho, o resultado deverá ser apresentado em encontros científicos e divulgado em revistas científicas. A qualquer momento poderá deixar de participar da pesquisa e isso não vai interferir no seu tratamento aqui no hospital.

Com este trabalho será possível ajudar a equipe de saúde a cuidar de crianças e adolescentes com câncer durante a quimioterapia, incluindo no cuidado as opiniões, desejos e necessidades, de acordo com a visão de vocês os pacientes. 
Caso você queira se comunicar conosco, o endereço é Escola de Enfermagem de Ribeirão Preto - USP, Avenida Bandeirantes no 3900, fone (16) 3602-3411 (Profa. Regina Lima) e o meu celular (Elizelaine) é (16) 8113-3221.

Elizelaine de Chico Cicogna Mestranda da EERP
Profa. Dra. Regina A. Garcia de Lima Professora da EERP e orientadora

Após ter conhecimento sobre como colaborar com esta pesquisa, concordo com a participação.

Eu, aceito que meu filho/minha filha participe da entrevista do projeto de pesquisa "Crianças e adolescentes com câncer: experiências com a quimioterapia". Estou ciente de que a entrevista será gravada, as informações serão mantidas em segredo e caso decida que meu filho/minha filha não deva mais participar, em qualquer momento, tenho a liberdade de retirar o consentimento. Recebi uma cópia deste documento e tive a oportunidade de discuti-lo com a interessada.

Nome do responsável:

Assinatura do responsável:

Nome da criança/adolescente:

Assinatura da criança/adolescente:

Data: / Ribeirão Preto-SP 
APÊNDICE II - Instrumento de Coleta de dados - Entrevista

Dados de identificação

Data:

Idade atual: anos

Data de Nascimento:

Religião:

Escolaridade:

Procedência:

Nome do(s) responsável(is):

Escolaridade / Profissão dos(s) responsável(is)

Diagnóstico

Tempo de diagnóstico:

Tratamento (s) realizado (s):

Medicamento(s) utilizado(s) no momento:

Internação no último ano: 


\section{Questões norteadoras}

- Conte-me o que sabe sobre a sua doença.

- O que você sabe sobre o seu tratamento?

- Conte-me o que é para você a quimioterapia.

- Você tem dúvidas sobre a quimioterapia? Quando tem, quem você procura para conversar?

- Como você se sente quando faz a quimioterapia?

- O quê mais lhe incomoda durante o tratamento? (procedimentos, exames, hospitalização, rotinas).

- Desde que você ficou doente, o que mais mudou na sua vida (com relação à doença e à quimioterapia)? (Casa, amigos, alimentação, relacionamentos, escolas, medicamentos, hospitalização, aspectos físicos - autoimagem, psicológicos).

- $O$ que você acha que poderia ser feito durante a quimioterapia para te ajudar?

- Como você pensa que será depois que terminar o tratamento?

- Tem algo que você acha importante dizer sobre tudo isso que não disse? 
APÊNDICE III - Instrumento de Coleta de dados - Observação

Data: ___ Início: Término:

Local:

Nome da criança/adolescente:

Observação de conversas informais, gestos, expressões, hábitos e costumes das crianças e adolescentes, assim como se portam durante a quimioterapia:

- ao chegar à unidade;

- ao aguardar a intervenção;

- durante a intervenção;

- $\quad$ após a intervenção. 
ANEXO 


\section{Aprovação do Comitê de Ética em Pesquisa}

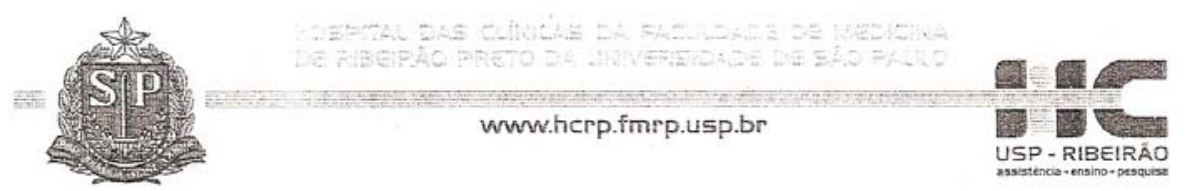

Ribeirão Preto, 26 de março de 2008

Oficio $n^{\circ} 1133 / 2008$

$\mathrm{CEP} / \mathrm{SPC}$

Prezada Senhora,

O trabalho intitulado "CRIANCAS E ADOLESCENTES COM CANCER: EXPERIWNCIAS COM A QUMMIOTERAPIA", foi analisado pelo Comitê de Ética em Pesquisa, em sua $263^{\text {a }}$ Reunião Ordinária realizada em 24/03/2008, e enquadrado na categoria: APROVADO, bem como o Termo de Consentimento Livre e Esclarecido, de acordo com o Processo HCRP n $2399 / 2008$.

Este Comitê segue integralmente a Conferência Internacional de Harmonizaçāo de Boas Práticas Clinicas (IGH-GCP), bem como a Resolução n 196/96 CNS/MS.

Lembramos que devem ser apresentados a este CEP, o Relatório Parcial e o Relatório Final da pesquisa.

Atenciosamente.

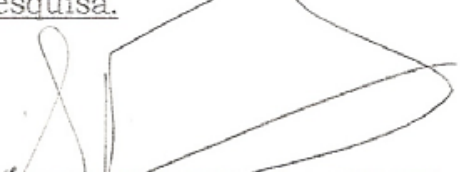

PROF. DR. SERGIO PEREHA DA CUNHA

Coordenador fo Comitê de Etica em Pesquisa do HCRP e da FMRP-USP

llustríssima Senhora

ELIZELAINE DE CHICO

PROF DR' REGINA APARECIDA GARCIA DE LIMA (Oxientadora)

Escola de Enfermagem de Ribeirão Preto-USP

FW/A - 00002733 ; IRB - 00002186 e Registro SISNEP/CONEP no 4

Fone (16) 3602-2228 - E-mail : cep a herp. fmrp.usp. br

Monte Alegre 14048-900 Ribeirão Preto SP 